\title{
ASSESSMENT OF GEOMORPHOLOGY AND GEOLOGIC HAZARDS IN THE PARKS HIGHWAY-MINTO FLATS-DALTON HIGHWAY INFRASTRUCTURE CORRIDOR: COOK INLET TO PRUDHOE BAY, ALASKA
}

Rich D. Koehler, Richard D. Reger, Eleanor R. Spangler, and Trent D. Hubbard

Report of Investigation 2019-8
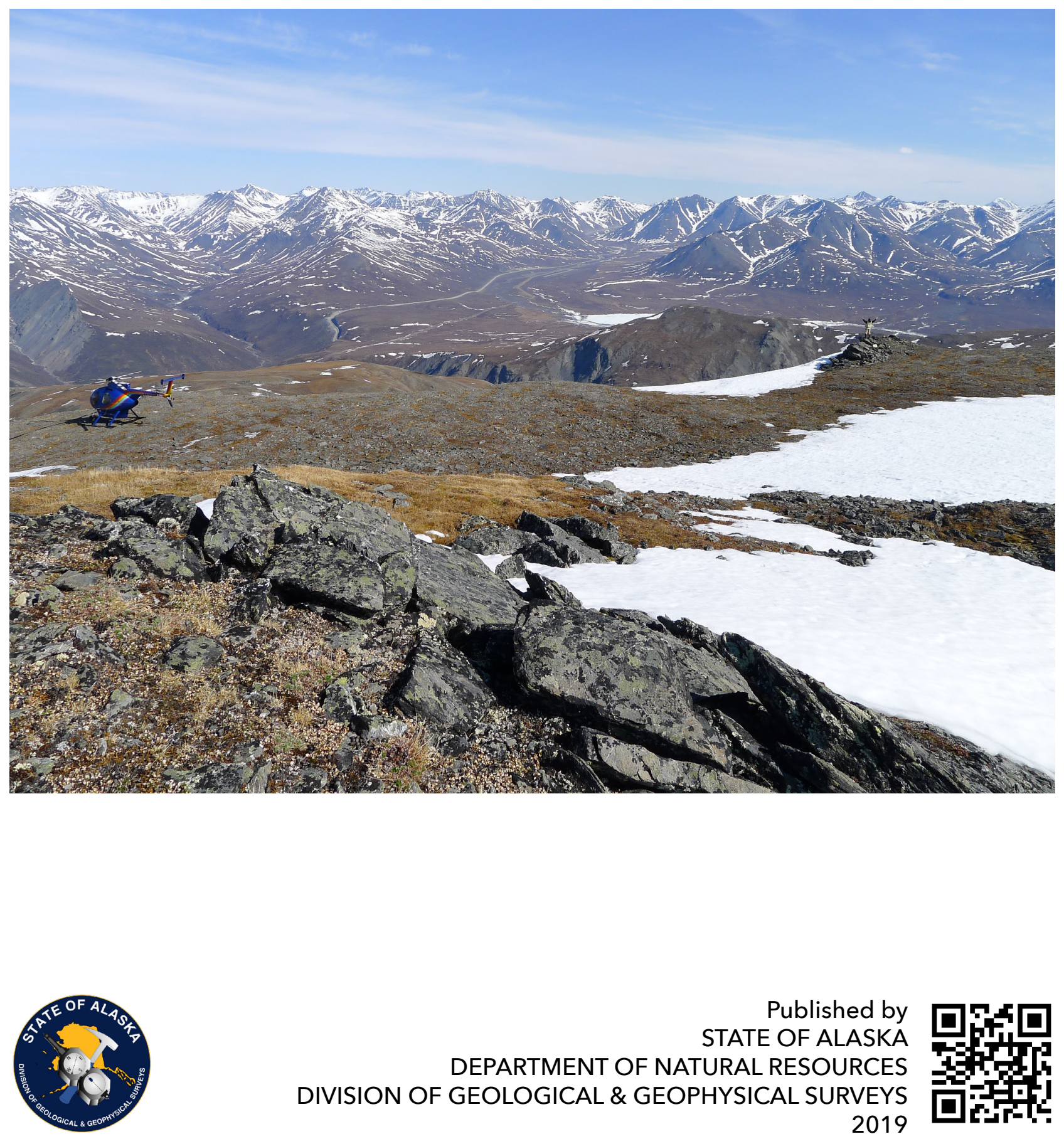
Cover. View of Chandalar Shelf and Atigun Pass from Table Mountain. Steep slopes and frost-shattered bedrock contribute to high debris-flow, slush-flow, and avalanche hazards along this section of the Dalton Highway and TransAlaska Pipeline System. Photo by Rich Koehler. 


\section{ASSESSMENT OF GEOMORPHOLOGY AND GEOLOGIC HAZARDS IN THE PARKS HIGHWAY-MINTO FLATS-DALTON HIGHWAY INFRASTRUCTURE CORRIDOR: COOK INLET TO PRUDHOE BAY, ALASKA}

Rich D. Koehler, Richard D. Reger, Eleanor R. Spangler, and Trent D. Hubbard 
STATE OF ALASKA

Michael J. Dunleavy, Governor

DEPARTMENT OF NATURAL RESOURCES

Corri A. Feige, Commissioner

DIVISION OF GEOLOGICAL \& GEOPHYSICAL SURVEYS

Steve Masterman, State Geologist and Director

Publications produced by the Division of Geological \&

Geophysical Surveys (DGGS) are available for free download from the DGGS website (dggs.alaska.gov). Publications on hard-copy or digital media can be examined or purchased in the Fairbanks office:

Alaska Division of Geological \& Geophysical Surveys

3354 College Rd., Fairbanks, Alaska 99709-3707

Phone: (907) 451-5010 Fax (907) 451-5050

dggspubs@alaska.gov | dggs.alaska.gov

DGGS publications are also available at:

Alaska State Library,

Historical Collections \& Talking Book Center

395 Whittier Street

Juneau, Alaska 99811

Alaska Resource Library and Information Services (ARLIS)

3150 C Street, Suite 100

Anchorage, Alaska 99503

Suggested citation:

Koehler, R.D., Reger, R.D., Spangler, E.R., and Hubbard, T.D., 2019, Assessment of geomorphology and geologic hazards in the Parks HighwayMinto Flats-Dalton Highway infrastructure corridor: Cook Inlet to Prudhoe Bay, Alaska: Alaska Division of Geological \& Geophysical Surveys Report of Investigation 2019-8, 82 p., 4 sheets. doi.org/10.14509/30100

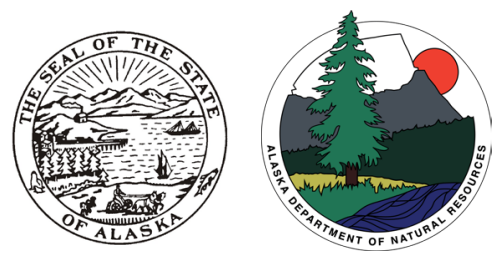




\section{Contents}

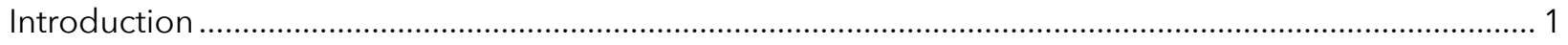

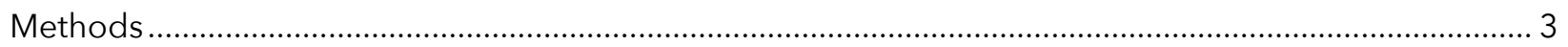

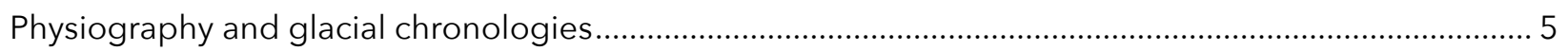

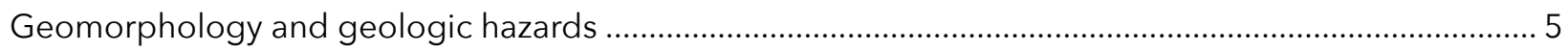

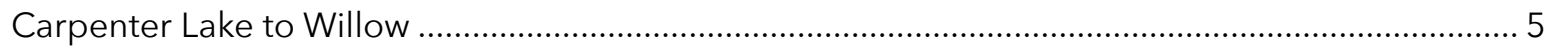

Tyonek B-1 and C-1 quadrangles,

1:63:360 scale

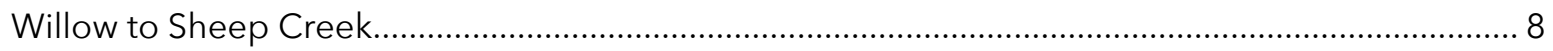

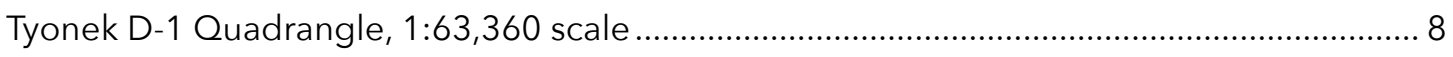

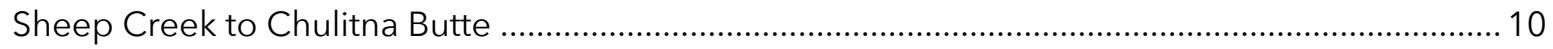

Talkeetna A-1, B-1, C-1, and D-1 and Talkeetna Mountains D-6 quadrangles,

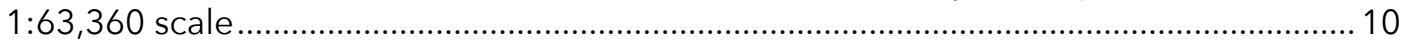

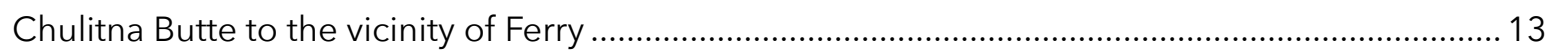

Healy A-5, A-6, B-4, B-5, C-4, D-4, and D-5 quadrangles, 1:63,360 scale ............................. 13

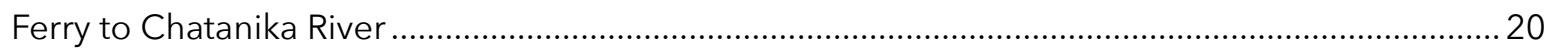

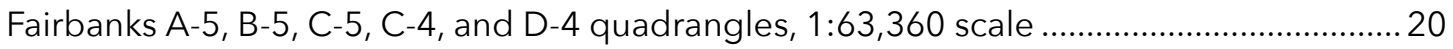

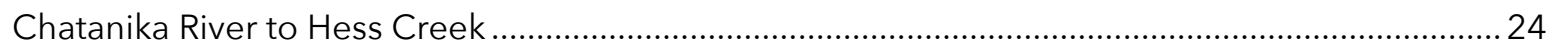

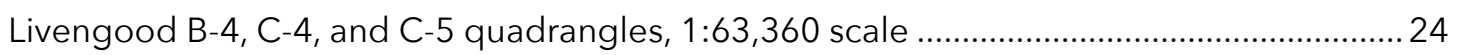

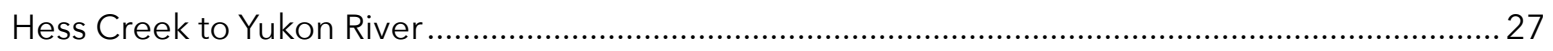

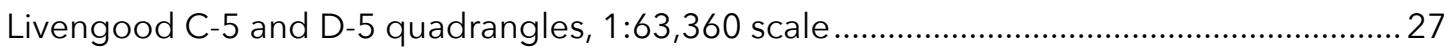

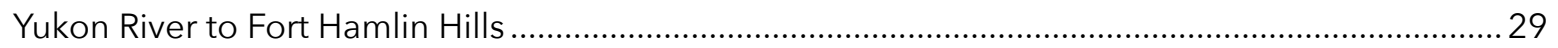

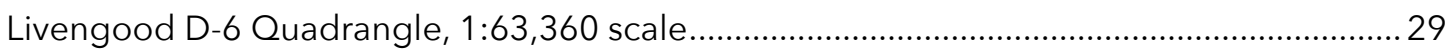

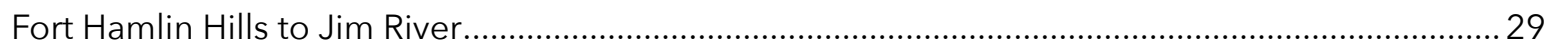

Tanana D-1 and Bettles A-1, B-1, B-2, C-2, D-1, and D-2 quadrangles, 1:63,360 scale.........29

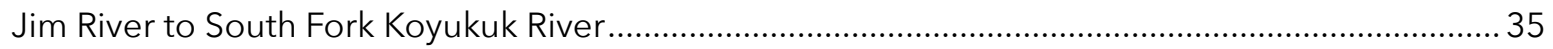

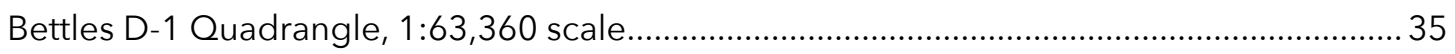

South Fork Koyukuk River to Middle Fork Koyukuk River (boundary of Wiseman and

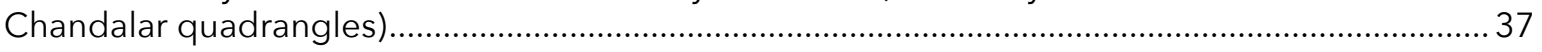

Wiseman A-1 and B-1 quadrangles,

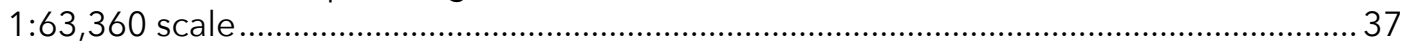

Middle Fork Koyukuk River to Dietrich River and Table Mountain ................................................... 39

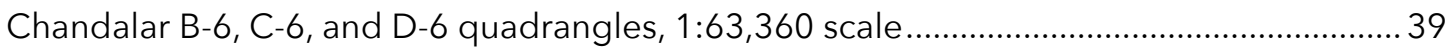

Uppermost Dietrich River and Table Mountain to Atigun River Gorge ............................................ 41

Philip Smith Mountains A-4, A-5, B-4, and B-5 quadrangles, 1:63,360 scale.......................... 41

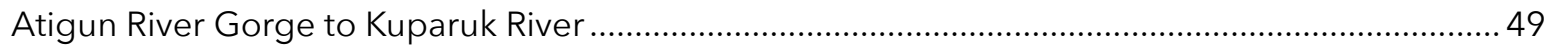

Philip Smith Mountains B-4, B-5, and C-5 quadrangles, 1:63,360 scale ............................. 49

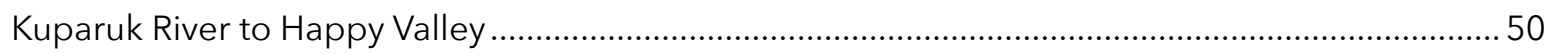

Philip Smith Mountains C-4, D-4, and D-3 and Sagavanirktok A-3 and A-4 quadrangles,

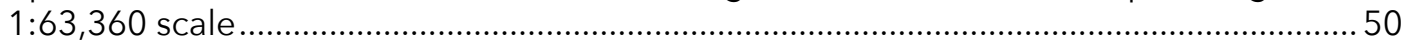

Happy Valley area to Sagwon Bluffs area (TAPS Pump Station 2) ................................................ 51

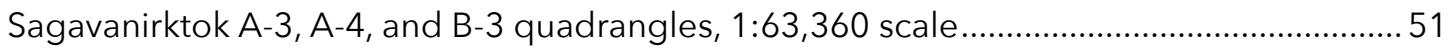

Sagwon Bluffs (TAPS Pump Station 2) to TAPS Pump Station 1 ................................................... 52

Sagavanirktok B-3, C-3, D-3, and D-4 and Beechey Point A-3, A-4, and B-3 quadrangles,

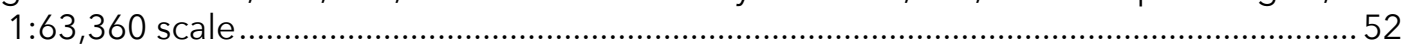

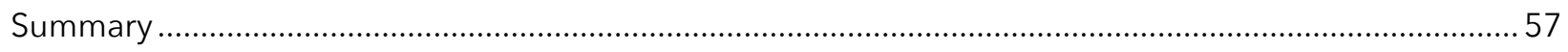

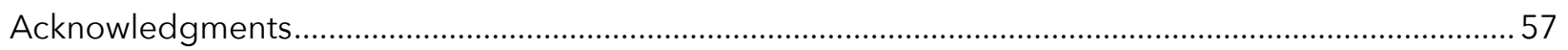

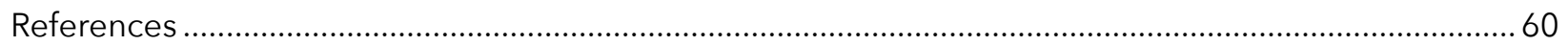




\section{Figures}

Figure 1. Map showing locations of lidar data collected along infrastructure corridors........................... 2

Figure 2. Map identifying 1:63,360-scale quadrangles referenced in text .............................................. 4

Figure 3. Photographs of small lake and sand dune complexes near southern end of corridor, and vegetation lineament along the Castle Mountain fault......

Figure 4. Photograph of sandy glaciomarine braid plain along the west bank of the Susitna River, and aerial photograph of string bogs and sand dunes along the corridor between the Susitna River and the Elmendorf moraine

Figure 5. Photographs of Montana Creek channel incised into hummocky till and outwash alluvium, and the Parks Highway bridge over the Susitna River

Figure 6. Photograph along the Parks Highway north of the Susitna River bridge, showing ground moraine and outwash terraces and numerous isolated sand dunes and sand dune complexes... 12

Figure 7. Photograph of Chulitna River gorge.

Figure 8. Photographs showing Panorama Mountain near the Jack/Nenana rivers confluence; close-up view of the massive Panorama Mountain rock avalanche deposit; and the side of the Panorama Mountain, showing intensely jointed and fractured volcanic rocks.

Figure 9. Photograph of irregular knob-and-kettle topography on sandy, granular till of Riley Creek glaciation south of the Yanert Fork Nenana River

Figure 10. Photographs of Nenana River gorge's steep eastern wall near the Parks Highway bridge, and western wall along Alaska Railroad, showing active debris-flow canyons and landsliding

Figure 11. Photographs of Healy terminal moraine and Riley Creek outwash terrace surfaces near the town of Healy, and Dry Creek alluvial valley north of the Healy terminal moraine.

Figure 12. Photograph of thin outwash terraces over Tertiary bedrock on both sides of the Nenana River north of Dry Creek .....

Figure 13. Photograph of a high outwash terrace surface associated with the Browne glaciation along the eastern side of the Nenana River....

Figure 14. Photograph showing organic-rich swamp deposits, sand dunes, and fine-grained channel fillings that characterize the Tanana lowland from Clear Air Force Base to Nenana.

Figure 15. Photograph of abandoned Tanana River floodplain channel, isolated sand dunes, thaw lakes, and polygonal ground that characterize the corridor near Goldstream Creek

Figure 16. Photograph of Tolovana River floodplain south of Livengood; typical landforms include open-system pingos, thermokarst ponds, and abandoned oxbow meanders .

Figure 17. Photographs of the Yukon River's southern bluff, and the 2012 landslide directly west of the Yukon River bridge

Figure 18. Photographs showing low slopes of ice-rich, retransported loess directly north of the Yukon River bridge, and the Ray River lowland near its confluence with the Yukon River ......... 30

Figure 19. Photographs showing low slopes of ice-rich, retransported loess directly north of the Yukon River bridge, and the Ray River lowland near its confluence with the Yukon River .........31

Figure 20. Photographs of residual outcrops directly south of Olsons Lake basin, and of Olsons Lake basin, characterized by thaw lakes and polygonal ground.....

Figure 21. Photograph showing prominent tors on ridge crests north of the Kanuti River ..................... 34

Figure 22. Photograph of Jim River floodplain near Douglas Creek

Figure 23. Photographs of corridor in Grayling Lake area, showing small, smooth, colluvial fans along the northwestern valley wall, and coarse rock rubble fans along the southeastern valley wall.

Figure 24. Photograph of terminal moraine of Itkillik glaciation north of the South Fork Koyukuk River. 
Figure 25. Photograph from Cathedral Mountain of the Middle Fork Koyukuk River and

Rosie Creek alluvial fan.

Figure 26. Photograph showing alluvial fans along tributaries to the Middle Fork Koyukuk River, including Nugget, Gold, and Linda creeks .

Figure 27. Photograph from Sukakpak Mountain looking toward the junction of the Middle Fork Koyukuk, Bettles, and Dietrich rivers.

Figure 28. Photographs of massive, creeping, frozen colluvial debris lobes along both sides of the Dietrich River valley, and of actively advancing tongue of frozen debris near Dalton Highway MP 219

Figure 29. Photograph showing alluvial fans, floodplain terraces, and thin till along the valley margins of the Dietrich River south of Nutirwik Creek

Figure 30. Photograph of massive, deep-seated landslides in bedrock north of Nutirwik Creek along the western margin of the upper Dietrich River....

Figure 31. Photographs of U-shaped valley extending from the Chandalar shelf to Atigun Pass, and active slush-flow fan at Chandalar Camp.

Figure 32. Photographs of slush-flow chute that released snow, blocks of ice, and large boulders in spring 2013, and of the slush-flow fan and 2013 deposit.

Figure 33. Photographs of upper Atigun River south of the Atigun River bridge on the Dalton Highway, and of Atigun River valley north of the Atigun River bridge.

Figure 34. Photograph of bimodal failures in parabolic dunes west of Pump Station 4, south of Galbraith Lake....

Figure 35. Photograph of glacial drift of Sagavanirktok glaciation extending north of Slope Mountain.....

Figure 36. Photographs of braided channels of the Sagavanirktok River floodplain south of its confluence with the Ivishak River, and of Cretaceous bedrock exposed in the Sagwon Bluffs....... 53

Figure 37. Photograph of the Sagavanirktok River near Franklin Bluffs, where it has incised the Arctic Coastal Plain

Figure 38. Photographs illustrating landforms on the Arctic Coastal Plain west of Franklin Bluffs, including pingo and polygonal ground, thick tussocks and complex ice-wedge polygons, and oriented thaw lakes

Figure 39. Photograph of Pump Station 1, showing the Beaufort Sea and Prudhoe Bay in the background.....

\section{Tables}

Table 1. Comparison of Pleistocene glacial chronologies used in different corridor segments.

Table 2. Summary of potentially important geologic hazards present in each sub-section of the corridor.....

\section{Appendix}

Appendix A. Map symbols for observation points along the Parks Highway, Minto Flats, and

Dalton Highway infrastructure corridors

Appendix B. List of references for previously mapped faults shown on map sheets 1-4 



\title{
ASSESSMENT OF GEOMORPHOLOGY AND GEOLOGIC HAZARDS IN THE PARKS HIGHWAY-MINTO FLATS-DALTON HIGHWAY INFRASTRUCTURE CORRIDOR: COOK INLET TO PRUDHOE BAY, ALASKA
}

\author{
Rich D. Koehler ${ }^{1}$, Richard D. Reger², Eleanor R. Spangler ${ }^{3}$, and Trent D. Hubbard ${ }^{4}$
}

\begin{abstract}
Field investigations in the Parks Highway, Minto Flats, and Dalton Highway infrastructure corridors were conducted by the Alaska Division of Geological \& Geophysical Surveys (DGGS) to support engineering-geologic decisions related to the planning, routing, and construction of future infrastructure development. Airphoto and lidar hillshade interpretations, helicopter surveys, and ground reconnaissance surveys were conducted in the $\sim 700$-mi-long by $\sim 1$-mi-wide corridor between Cook Inlet and Prudhoe Bay to develop information about landscape geomorphology and evaluate potential geologic hazards. The corridor crosses diverse terrain, several major mountain ranges, and 12 physiographic provinces. We identified a wide variety of geologic hazards along the corridor that are a product of local geomorphic conditions.

This report documents our Quaternary geologic observations from the 2011, 2012, and 2013 field seasons and includes maps identifying specific geologic hazards in the infrastructure corridor. The methodology employed during this investigation, specifically concerning the evaluation of a long, relatively narrow swath across variable terrain, can be applied to other infrastructure corridor studies in Alaska and elsewhere.
\end{abstract}

\section{INTRODUCTION}

The Parks Highway, Minto Flats, and Dalton Highway infrastructure corridors (fig. 1) combine to provide an important land-transportation link between Anchorage and the North Slope. This composite infrastructure corridor (herein referred to as "the corridor") connects the state's major population centers of Anchorage and Fairbanks and provides an important connection to the North Slope oil production region, essential for the support, transport, and delivery of petroleum products to market. Several natural gas pipelines have been proposed for development in the corridor. In 2011, the Alaska Division of Geological \& Geophysical Surveys (DGGS) acquired lidar along the corridor to facilitate the evaluation of geologic hazards (Hubbard and others, 2011a). This acquisition was supported by the Alaska State Pipeline Coordinator's Office (SPCO), the Office of the Federal Coordinator for Alaska Natural Gas Transportation Projects, and the Alaska Gasline Development Corporation (AGDC).

From 2011 to 2013, DGGS conducted helicopter surveys and ground reconnaissance studies supported by AGDC to document landscape geomorphology and evaluate geologic hazards in the -700-mi-long by $\sim 1$-mi-wide corridor between Cook Inlet and Prudhoe Bay (fig. 1). The purpose of these investigations was to provide geomorphic and geologic hazard information to aid in the planning,

\footnotetext{
${ }^{1}$ Alaska Division of Geological \& Geophysical Surveys, 3354 College Road, Fairbanks, Alaska 99709-3707; now at Nevada Bureau of Mines and Geology, Mackay School of Earth Science and Engineering, University of Nevada, Reno, 1664 North Virginia Street, MS 178, Reno, NV 89557

${ }^{2}$ Reger's Geologic Consulting, P.O. Box 3326, Soldotna, AK 99669

${ }^{3}$ Alaska Division of Geological \& Geophysical Surveys, 3354 College Road, Fairbanks, Alaska 99709-3707; now at California Geological Survey, 801 K Street, MS 12-31, Sacramento, CA 95814

${ }^{4}$ Alaska Division of Geological \& Geophysical Surveys, 3354 College Road, Fairbanks, Alaska 99709-3707; trent hubbard@alaska.gov
} 


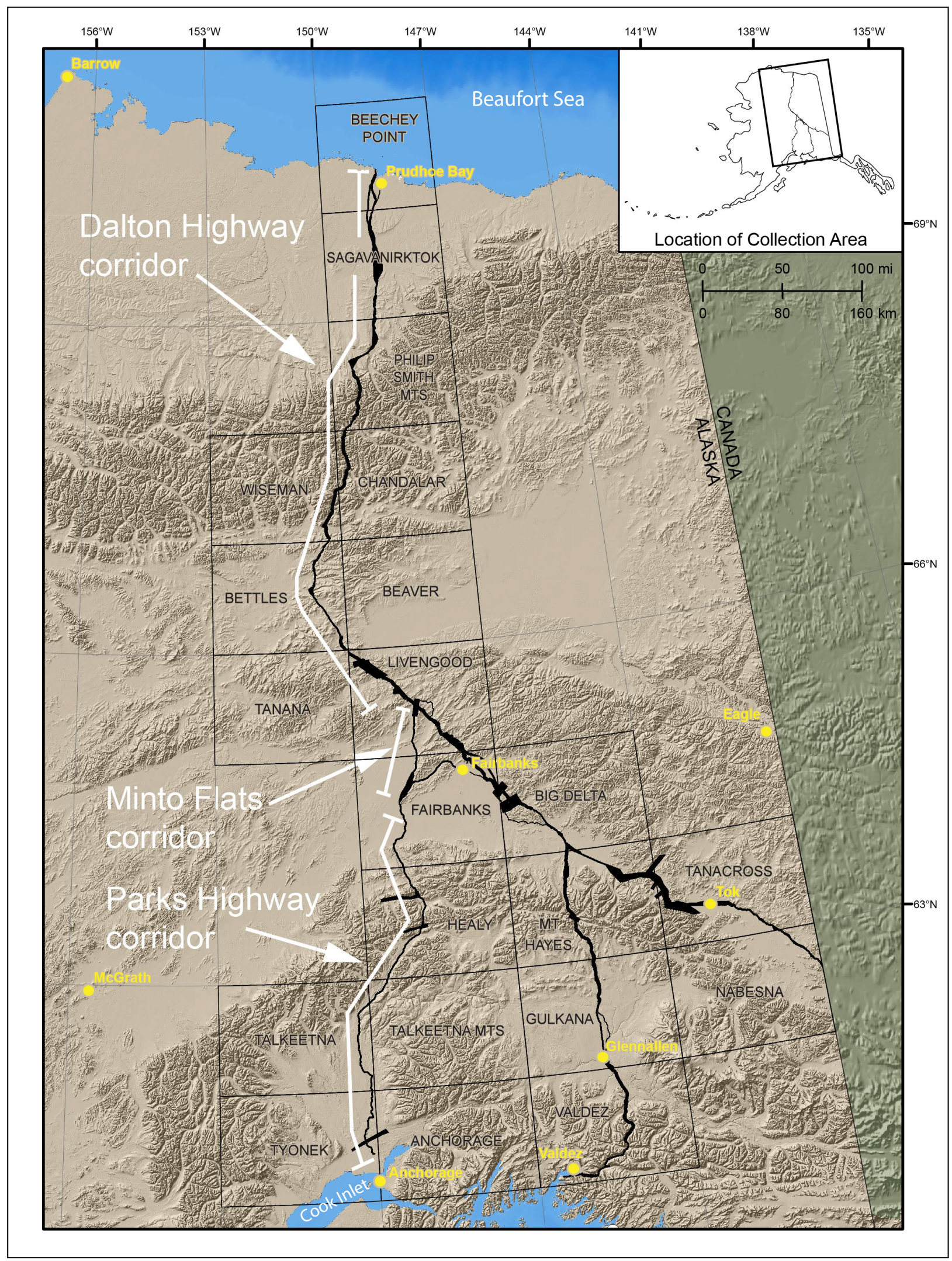

Figure 1. Map showing locations of lidar data (black shaded areas) collected along infrastructure corridors. The Parks Highway, Minto Flats, and Dalton Highway infrastructure corridors, which are the focus of this geomorphic and geologic hazards evaluation, are indicated with white bars. Lidar data shown are available to the public through the Division of Geological \& Geophysical Surveys' Elevation Datasets of Alaska online application (https://elevation.alaska.gov; http:// doi.org/10.14509/25239). Labeled rectangles are U.S. Geological Survey (USGS) 1:250,000 scale quadrangles. 
design, and construction of a variety of infrastructure components including, but not limited to, natural-gas pipelines, railroads, telecommunications networks, and highways. This report summarizes the geomorphic and geologic hazard observations for the entire corridor.

\section{METHODS}

Landscape geomorphology and geologic hazards were initially evaluated by interpreting - 1:65,000-scale false-color infrared stereo aerial photographs from the NASA Ames Research Center's Alaska High Altitude Photography (AHAP) collection, acquired from the University of Alaska Fairbanks. Other imagery evaluated during the initial phase of the project included GoogleEarth and Landsat images available through ESRI's ArcGIS Online. A literature review of published maps and reports was conducted to help focus the imagery assessment. The airphoto and imagery analyses focused on identifying geologic processes and conditions with the potential to adversely impact future infrastructure development in the corridor, including slope instability, flooding, permafrost, aufeis, slush-flow, avalanche, and other hazards.

Observations made from the imagery analyses were compiled on topographic base maps and used to guide field investigations. Helicopter surveys and limited ground reconnaissance were conducted along the entire length of the corridor. Bare-earth digital elevation models (DEMs) created from the Alaska infrastructure corridor lidar dataset acquired in 2011 (Hubbard and others, 2011a) were used to generate hillshade model base maps at a scale of 1:24,000. The purpose of the field investigation was to verify imagery interpretations and to observe the landscape from different altitudes and angles not possible with traditional airphoto interpretation techniques. The lidar hillshade base maps proved to be the most useful type of remotely sensed data for identifying and characterizing landscape geomorphology, particularly in areas of dense vegetation. Evaluation of the lidar data in the field during our reconnaissance surveys served to improve and refine our initial airphoto and imagery interpretations.

The combined imagery, lidar data, and field observations are described from south to north and are organized by 1:63,360-scale quadrangle (fig. 2). In areas where the corridor extends across short sections of a particular quadrangle and/or where similar deposits extend across quadrangle boundaries, several quadrangles are grouped together into a single section. For infrastructure engineering purposes, distances are reported in U.S. units, however, elevations, thicknesses, and other observations are reported in both U.S. and metric units. Notable geologic hazards and unique geomorphic landforms are depicted on four sheets at a scale of 1:100,000 (sheets 1-4). Individual maps on those four sheets are numbered consecutively from south (1) to north (12) and overlap at their boundaries. The reader is advised to refer to the original topographic maps for geographic localities described in the text; however, important localities that are obscured on the maps are labeled for convenience. A table describing the lettered abbreviations of landforms and geologic hazards shown as points on the maps is provided in Appendix A. Individual observation points where more specific information is available such as field measurements, features related to specific dated glacial advances, or features that do not fit into more general categories are numbered on the maps and described in Appendix A.

Surficial-geologic mapping of individual deposits and terrain unit mapping was beyond the scope of this project; however, surficial-geologic mapping at a scale of 1:63,360 was performed along the Alaska Highway corridor by Reger and others (in press). Surficial-geologic mapping could be applied to this corridor in the future to facilitate development of engineering-geologic maps, which group surficial deposits with common properties significant for engineering purposes. 


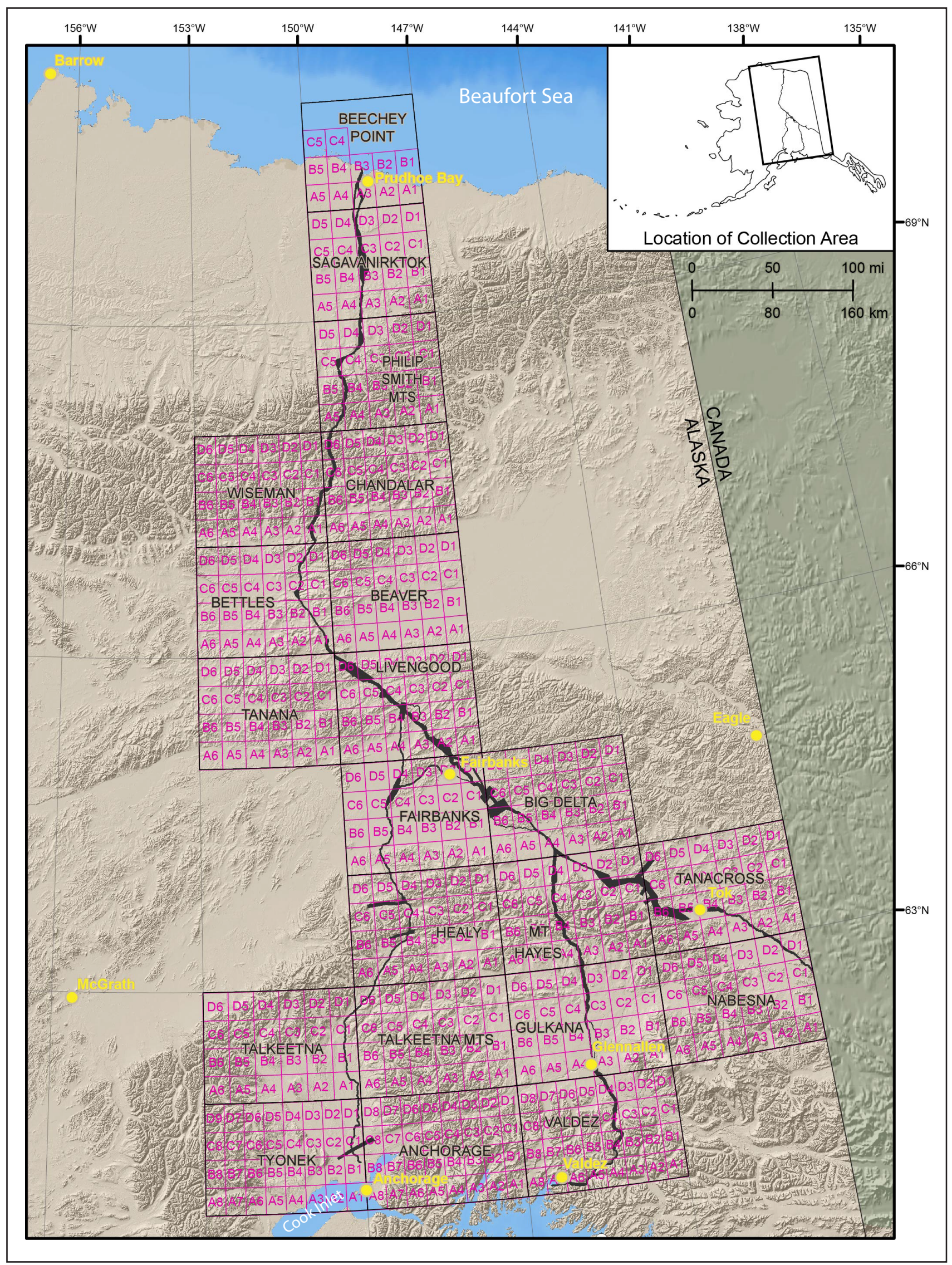

Figure 2. Map identifying USGS 1:63,360-scale quadrangles referenced in text. Black shaded areas show locations of lidar data collected along infrastructure corridors. 
Locations of previously mapped tectonic faults are shown on the map sheets, and the original references for each fault are provided in Appendix B. The faults include active and potentially active faults from the Alaska Quaternary Fault and Fold Database (Koehler and others, 2012a; Koehler, 2013) as well as inactive bedrock faults mapped by others. We discuss only general characteristics of these faults where they cross the infrastructure corridor. More detailed information on slip rates and fault rupture parameters are described elsewhere in other papers and professional conference abstracts available online, including Koehler and others (2016); Koehler and others (2014); Koehler and Reger (2014); Koehler and others (2013a,b); Koehler and others (2012b); Koehler (2011); Hubbard and Koehler (2014); and Hubbard and others (2011b).

\section{PHYSIOGRAPHY AND GLACIAL CHRONOLOGIES}

The -700-mi-long corridor extends from Cook Inlet to Prudhoe Bay. Climate and vegetation patterns change dramatically along the corridor's length, and many sections cross rugged, relatively inaccessible terrain. Topography along the corridor varies considerably and includes areas of relatively flat lowlands and plains, plateaus, and highlands of rolling topography and gentle slopes; low, rolling mountains; moderately high, rugged mountains; and extremely high, rugged mountains (Wahrhaftig, 1965). Physiographic regions along the corridor from south to north include Cook Inlet-Susitna Lowland, Talkeetna Mountains, central Alaska Range, Northern Foothills of the Alaska Range, Tanana-Kuskokwim Lowland, Yukon-Tanana Upland, Rampart Trough, Kokrine-Hodzana Highlands, Ambler-Chandalar Ridge and Lowland section, central Brooks Range, Arctic Foothills, and Arctic Coastal Plain (Wahrhaftig, 1965).

From south to north through the corridor, Pleistocene glacial chronologies used in this report change between physiographic provinces (table 1). The chronology for the Cook Inlet basin extends northward from the southern end of the corridor to Healy in the central Healy B-4 Quadrangle because glacial ice was contributed to the Cook Inlet basin from the south-central Alaska Range and the Talkeetna Mountains. North of Healy, ice from the central Alaska Range flowed northward into the Nenana River valley, where the late Pleistocene terminology of Wahrhaftig (1958) and the middle and early Pleistocene terminology of Thorson (1986) are used as far north as Nenana in the southern Fairbanks C-4 and C-5 quadrangles. Ten Brink and Waythomas (1985) expanded investigation of the last major glaciation in the north-central Alaska Range and refined its stadial subdivisions. They suggested it be called the McKinley Park glaciation, where their chronology is best documented. Cosmogenic-exposure dating by Briner and Kaufman (2008) generally confirmed the stadial subdivisions proposed by Ten Brink and Waythomas (1985), which is based on numerous radiocarbon ages. However, age precedence and limitation of the corridor to the Nenana River drainage encourage us to retain Wahrhaftig's terminology. The Pleistocene glacial chronology for the central Brooks Range was developed by Hamilton (1979, 1994) during his extensive 1:250,000-scale geologic mapping in that region. During the early Pleistocene, Anaktuvuk River ice from the central Brooks Range spread as far southward as the south side of Prospect Creek in the southern Bettles B-2 Quadrangle and probably spread as far northward as the junction of the Sagavanirktok and Ivishak rivers in the north-central Sagavanirktok B-3 Quadrangle.

\section{GEOMORPHOLOGY AND GEOLOGIC HAZARDS}

\section{Carpenter Lake to Willow}

Tyonek B-1 and C-1 quadrangles, 1:63:360 scale

The southern end of the corridor begins in the Tyonek B-1 Quadrangle directly west of Carpenter Lake, from which it extends north and northwest. Geomorphic landforms along this section consist of low-relief, isolated remnants of the terminal moraine of the Knik lobe of the Elmendorf stadial glacial advance (Reger and Updike, 1983; Reger and others, 1995) and a relatively flat, glacial outwash plain (sheet 1, map 1). The outwash consists of 
Table 1. Comparison of Pleistocene glacial chronologies used in different corridor segments.

\begin{tabular}{|c|c|c|c|c|c|}
\hline \multirow{2}{*}{$\begin{array}{l}\text { Corridor } \\
\text { interval }\end{array}$} & \multicolumn{4}{|c|}{ Glaciation } & \multirow[b]{2}{*}{ References } \\
\hline & Last major (kya) & Penultimate & $\begin{array}{c}\text { Middle } \\
\text { Pleistocene }\end{array}$ & $\begin{array}{c}\text { Early } \\
\text { Pleistocene }\end{array}$ & \\
\hline $\begin{array}{l}\text { Cook Inlet } \\
\text { basin and } \\
\text { southcentral } \\
\text { Alaska Range }\end{array}$ & $\begin{array}{l}\text { Naptowne } \\
\text { Elmendorf stade } \\
(16.0-11.0) \\
\text { Skilak stade (18.0- } \\
16.0) \\
\text { Killey stade (19.0- } \\
18.0) \\
\text { Moosehorn stade } \\
(\sim 32-19.0)\end{array}$ & Unnamed & Unnamed & Unnamed & $\begin{array}{l}\text { Karlstrom } \\
\text { (1964) } \\
\text { Reger and } \\
\text { Updike } \\
\text { (1983) } \\
\text { Reger and } \\
\text { others (1995; } \\
\text { 2007) }\end{array}$ \\
\hline $\begin{array}{l}\text { Nenana River } \\
\text { valley and } \\
\text { north central } \\
\text { Alaska Range }\end{array}$ & $\begin{array}{l}\text { Riley Creek } \\
\text { Stade IV } \\
(10.5-9.5) \\
\text { Stade III = Carlo } \\
\text { readvance (12.8- } \\
11.0) \\
\text { Stade II } \\
(15.0-13.5) \\
\text { Stade I } \\
(26.0-17.0)\end{array}$ & Healy & $\begin{array}{l}\text { Lignite Creek } \\
\text { Bear Creek? }\end{array}$ & Browne & $\begin{array}{l}\text { Wahrhaftig } \\
\text { (1958) } \\
\text { Ten Brink and } \\
\text { Waythomas } \\
\text { (1985) } \\
\text { Thorson } \\
\text { (1986) } \\
\text { Briner and } \\
\text { Kaufman } \\
\text { (2008) }\end{array}$ \\
\hline $\begin{array}{l}\text { Central } \\
\text { Brooks Range }\end{array}$ & Itkillik II & Itkillik 1 & $\begin{array}{l}\text { Sagavanirktok } \\
\text { River }\end{array}$ & $\begin{array}{l}\text { Anaktuvuk } \\
\text { River }\end{array}$ & $\begin{array}{l}\text { Hamilton } \\
(1979 ; 1994)\end{array}$ \\
\hline
\end{tabular}

coarse granular to cobble material. This area also contains numerous small lakes, basins, sand dune complexes, and fluvial terraces associated with the Little Susitna River (fig. 3A).

North of the Little Susitna River the corridor extends roughly north-south through the center of the Tyonek C-1 Quadrangle across relatively flat alluvial topography between the Susitna River and a large north-south-trending terminal moraine associated with the Elmendorf stadial advance. A sanddune-covered portion of the moraine bounds the western sides of Cow Lake and Red Shirt Lake. Fish Creek is the largest drainage crossed by the corridor in this area; a few small streams are also crossed.

In the southern part of the Tyonek C-1 Quadrangle the corridor crosses the Castle Mountain fault, a northeast-southwest-trending, active oblique reverse fault. The fault is poorly expressed in the corridor, where the topography is relatively flat, and the only indication of the fault's presence is a vegetation lineament (fig. 3B). However, welldefined south-facing scarps $1.6-13.1 \mathrm{ft}(0.5-4 \mathrm{~m})$ high are present to the east and west of the corridor, indicating Holocene displacements. The trace of the fault is associated with a $0.47 \mathrm{mi}$ step across the corridor. Based on the lack of scarps in the corridor, the presence of scarps west of the alignment, and the step in the fault, we suggest that the zone of deformation may be as wide as $-.62 \mathrm{mi}$ and associated with north-side-up anticlinal folding. Further details on the paleoseismic history and rupture parameters of the Castle Mountain fault are described in Koehler and others (2016), Koehler and others (2012b), Koehler and others (2014), and Koehler and Reger (2014). 


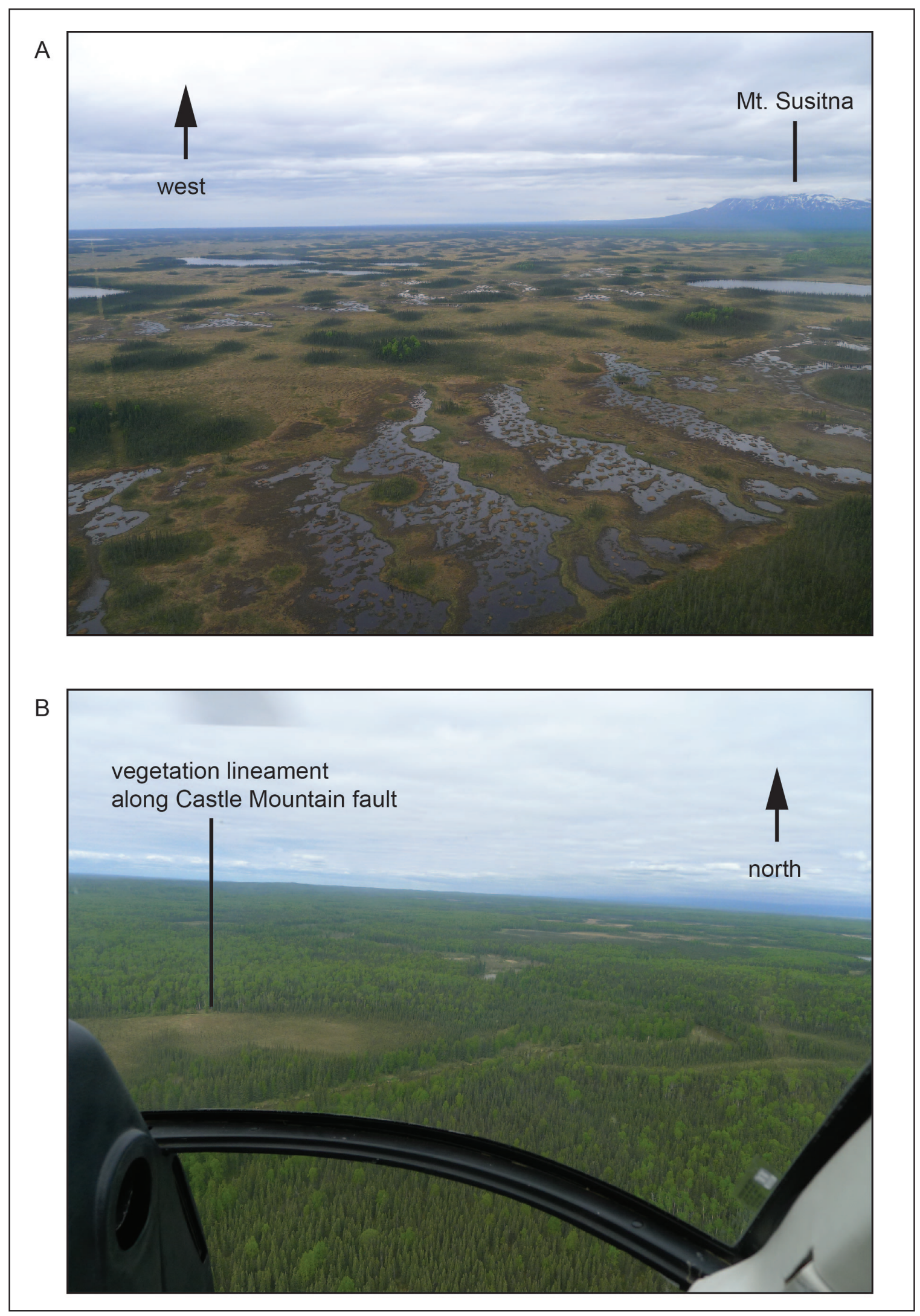

Figure 3. A. Westward view of small lake and sand dune complexes near the southern end of the corridor. B. View to the north, showing subtle vegetation lineament along the Castle Mountain fault. 
The region between the Susitna River and the Elmendorf moraine is characterized as a sandy braid plain (fan delta) related to glaciomarine invasion of the lower Susitna Basin during the late Naptowne glaciation (Skilak and Elmendorf stades) (table 1; fig. 4A). Small sand dunes and sand-dune complexes are scattered across the corridor surface and support stands of robust deciduous trees, including paper birch. The surficial deposits are underlain by the Bootlegger Cove Formation, a glaciomarine-glaciodeltaicglacioestuarine deposit consisting of thin to medium-thick beds (generally $<1 \mathrm{~m}$ to $10 \mathrm{~m}$ thick) of silty clay, silty fine sand, and sandy gravel (Ulery and Updike, 1983). The water table is high across the sand plain, and swampy conditions are common. Small lakes and ponds are abundant, including extensive string bogs scattered across the corridor surface west of Nancy Lake State Recreation Area (fig. 4B). An extensive complex of longitudinal sand dunes is present in the corridor along the western margin of the Elmendorf moraine from west of Red Shirt Lake to the vicinity of Rolly Creek. The saturated conditions and sandy substrate indicate that liquefaction due to seismic shaking is the dominant geologic hazard in this area.

At the northern end of the Tyonek C-1 Quadrangle the corridor crosses a large $(>50 \mathrm{ft}[>15.2$ $\mathrm{m}]$ high) terrace riser where the Susitna River has incised pitted glacial outwash of the Elmendorf stade. Several large rotational landslides, involving both the Bootlegger Cove Formation and the overlying fan-delta and pitted-outwash deposits, are present along the northwest-facing slope of the terrace riser.

\section{Willow to Sheep Creek}

\section{TYONEK D-1 QUADRANGLE, 1:63,360 SCALE}

Through the southern Tyonek D-1 Quadrangle the corridor extends $-3 \mathrm{mi}$ in an east-west orientation, where it traverses coarse-grained pitted-outwash and outwash-alluvial deposits. In the vicinity of the town of Willow, the corridor turns to the north and follows the Parks Highway near the eastern side of the quadrangle. The dominant Quaternary landforms in this section are outwash terraces, glacial moraines, and ice-stagnation deposits. Outwash and morainal deposits are crossed by the corridor west of the Parks Highway between Kashwitna Lake (sheet 1, map 1) and Sheep Creek (sheet 1, map 2) to the north. An end-moraine complex between Little Willow Creek and the Kashwitna River represents the Skilak stadial moraine of the complex Susitna River glacial lobe, sourced in the Alaska Range to the north and the Talkeetna Mountains to the east. A prominent sand-dune complex is present near the outpost of Caswell. Deposits associated with these landforms have been incised by the south-flowing Susitna River and relatively smaller west-flowing tributary drainages, including Willow Creek, Little Willow Creek, 196 Mile, and 197.5 Mile creeks, the Kashwitna River, Caswell Creek, and Sheep Creek. The tributary drainages are generally low gradient and characterized by tight meanders, tight oxbow lakes, and narrow floodplains. The margins of the floodplains are associated with steep terrace risers that are susceptible to slope-movement hazards, including rotational failures, earth flows and falls, and lateral spread. Channels associated with the modern Susitna River enclose forested islands; sand deposits on the forest floor indicate that the islands are periodically flooded. Aerial inspection of both the eastern and western banks of the Susitna River indicates that the outwash terrace surfaces are underlain by gray till capped by approximately 3.3-9.8 ft (1-3 m) of tan-brown glacial outwash sand and gravel.

Several potential areas for flooding and erosion hazards were observed along the corridor in the Tyonek D-1 Quadrangle. A large meander bend of the Susitna River is cut into an outwash terrace along the Parks Highway between 196 Mile Creek and the Kashwitna River. Similar Susitna River meanders and terrace risers are present at the mouths of Caswell Creek and Sheep Creek, and along the western side of the corridor. Future 


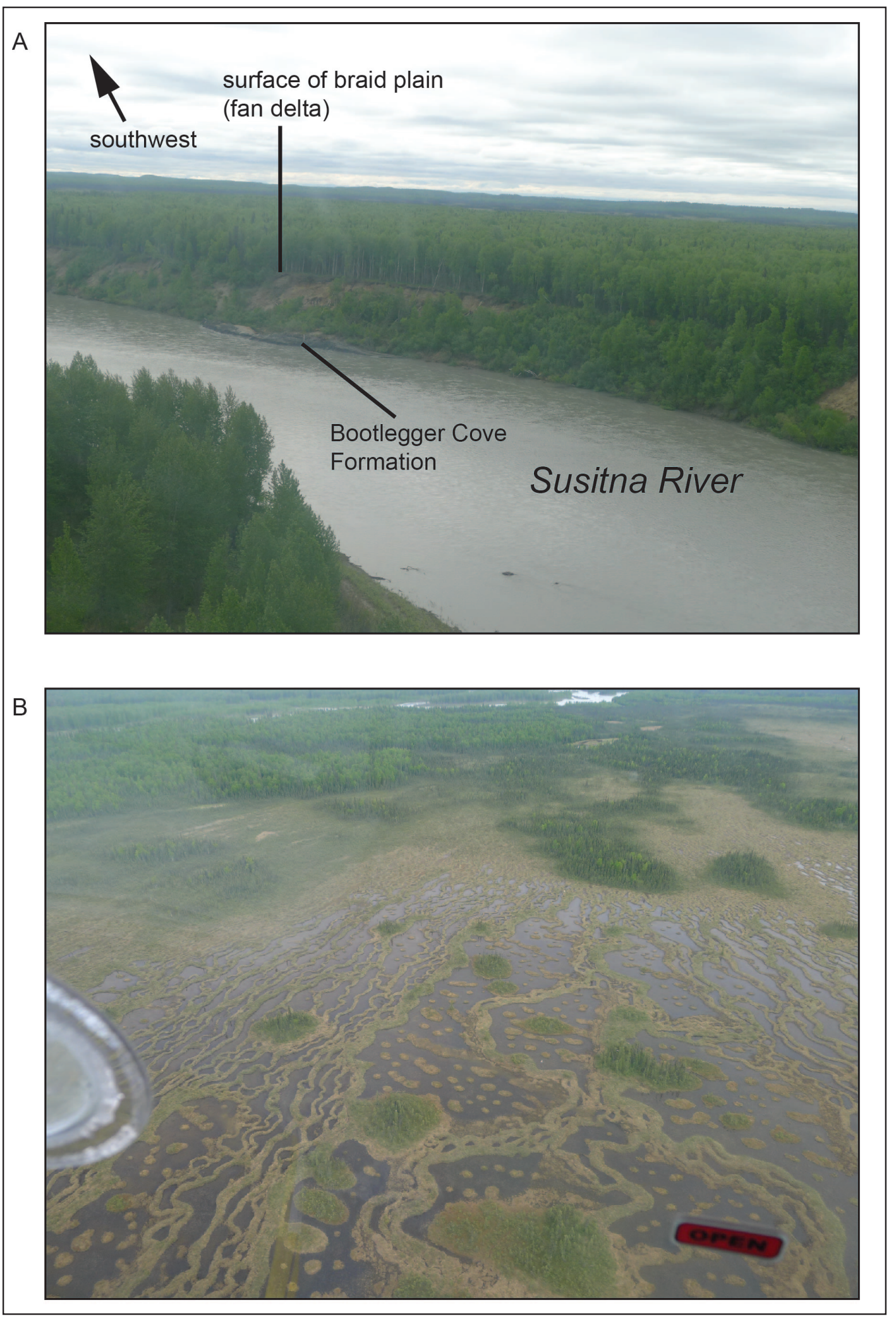

Figure 4. A. Surface of the sandy glaciomarine braid plain (fan delta) along the west bank of the Susitna River. The Bootlegger Cove Formation is exposed at the base of the bluffs (dark gray band). The sand plain extends between the Susitna River on the west and the Elmendorf terminal moraine on the east. B. Aerial photograph showing string bogs and vegetated sand dunes along the corridor surface between the Susitna River and the Elmendorf moraine. Red and black "OPEN" label in bottom right corner is attached to the helicopter window and is not meant to draw attention to any particular feature in the photo. 
potential flooding of the Susitna River across the meander floodplain surface could possibly erode and undermine the high terrace scarp. This process could result in bank failure or large landslides, potentially undermining infrastructure elements along the top of the terrace riser. We recommend that future infrastructure developers conduct additional site-specific studies at these locations to determine the potential for erosion and/or flood damage. Except for these sites, the majority of the corridor is relatively protected from flooding and erosion hazards by either being an adequate distance (> $1 \mathrm{mi}$ ) from the eastern bank of the Susitna River or because of protection provided by being on top of high scarps cut into the outwash terraces $(>65 \mathrm{ft}[>20 \mathrm{~m}]$ tall).

\section{Sheep Creek to Chulitna Butte}

TALKEETNA A-1, B-1, C-1, AND D-1 AND TALKEETNA MOUNTAINS D-6 QUADRANGLES, 1:63,360 SCALE

From the southern limit of the Talkeetna A-1 Quadrangle to the crossing of the Susitna River the corridor follows the Parks Highway along the eastern side of the Susitna River (sheet 1, map 2). There the corridor extends across a lowland plain underlain primarily by deposits related to the last major glaciation. This lowland generally stands well above the Susitna River except where tributary streams, such as Goose and Montana creeks, drain narrow, incised, alluvium-filled valleys graded to the Susitna River (fig. 5A). From the vicinity of Sheep Creek to the crossing of Goose Creek, the granular materials are coarse-grained outwash alluvium and ice-stagnation esker-kame complexes. Between Goose Creek and Montana Creek, the surficial deposits consist of till and outwash alluvium of the Skilak stadial advance. The Susitna River has incised the outwash alluvium directly south of the mouth of Montana Creek and formed a steep terrace riser, which is susceptible to future mass failures from ongoing exposure to flood flows.

North of Montana Creek the corridor extends about $7 \mathrm{mi}$ to the crossing of the Susitna River (fig.
5B). In this section, surficial deposits are characterized as gravel-rich, pitted outwash alluvium deposited on dead ice of the Skilak stade late in the last major (Naptowne) glaciation (Reger, 1978). A series of terraces related to the downcutting of Montana Creek into the outwash alluvium is preserved along the eastern side of the corridor for about 1.5 mi north of Montana Creek. The pitted outwash transitions to silty till of the Skilak stade for the last mile before the Susitna River bridge. In this area, Sunshine Creek and the Susitna River have eroded a steep, north-facing escarpment more than $100 \mathrm{ft}(30.5 \mathrm{~m})$ high. The Susitna River has also eroded an equally-steep, south-facing escarpment on its north-northwest bank near the bridge. Cuspate landslide headscarps and pervasive gullies (some up to $50 \mathrm{ft}[15.2 \mathrm{~m}]$ wide) indicate that the till subsurface materials in this area are highly susceptible to slope failure (sheet 1, map 2).

From the crossing of the Susitna River the corridor continues north along the Parks Highway and Rabideux Creek for approximately $13 \mathrm{mi}$ to the Trapper Creek vicinity. In this area the corridor follows outwash terraces related to the Susitna River along the eastern margin of a broad plain of dense, fluted ground moraine. The ground moraine and outwash terraces are blanketed by $10-15 \mathrm{ft}(3-4.6$ $\mathrm{m}$ ) of eolian sand likely derived from formerly unvegetated floodplain bars to the east (fig. 6). Numerous isolated sand dunes and sand dune complexes are also present. About $0.5 \mathrm{mi}$ north of Trapper Creek, the corridor extends across the terminal moraine of the Elmendorf stade (site 31, sheet 1, map 2, Lat./Long. 62.3227, -150.2519). The end moraine has been modified by glaciofluvial processes, and numerous kame terraces, eskers, and abandoned meltwater channels characterize the landscape. North of the end moraine the corridor extends for $9 \mathrm{mi}$ across the fluted till surface to the vicinity of Denali Lake (the northern limit of the Talkeetna B-1 Quadrangle). Several prominent abandoned meltwater channels are present along the eastern side of the corridor. The western margin of the Chulitna River coincides with the eastern edge of 


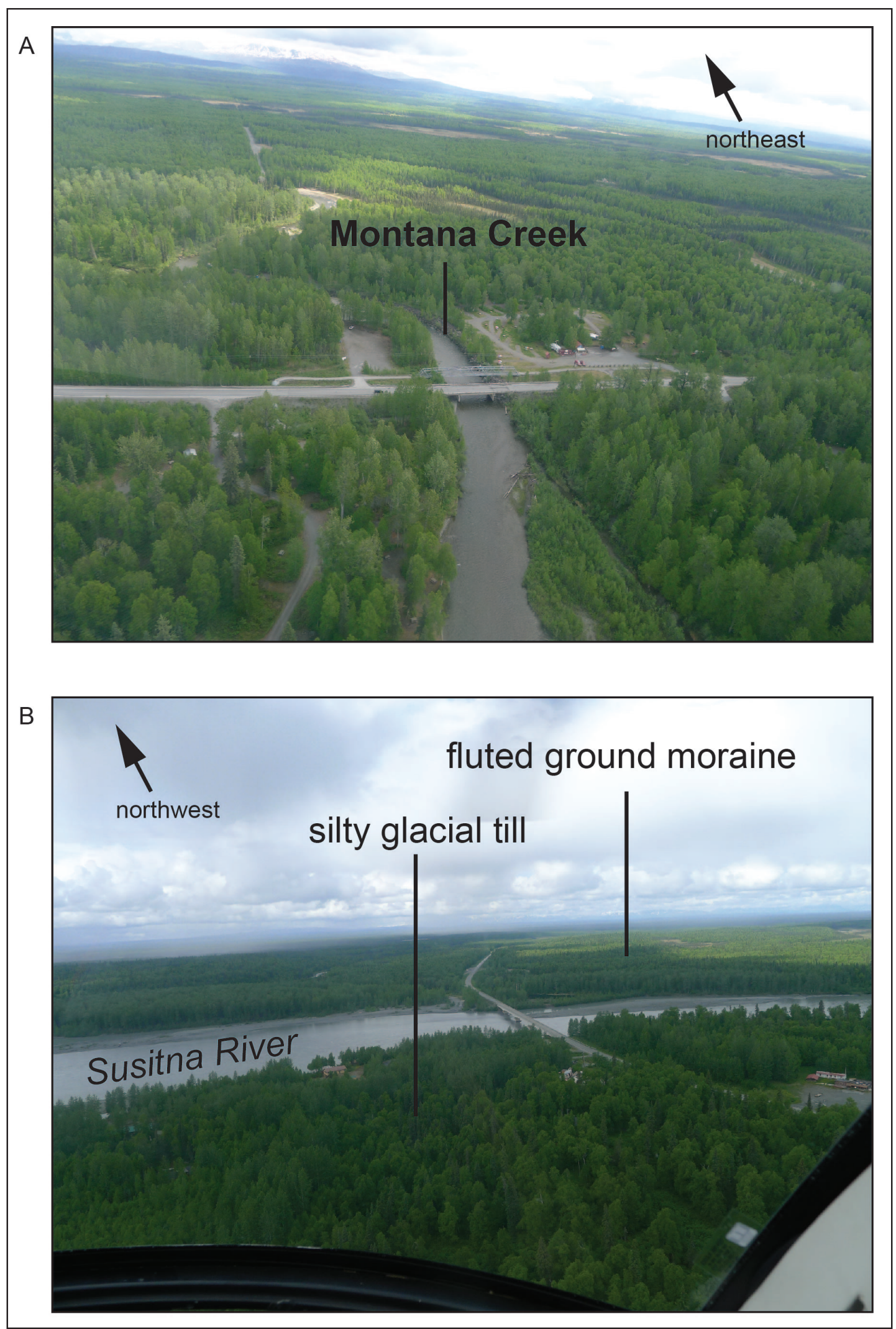

Figure 5. A. View to northeast across the Parks Highway bridge, showing channel of Montana Creek incised into hummocky till and outwash alluvium. B. View to northwest of the Parks Highway bridge over the Susitna River. The southeast bank of the river consists of silty till. 


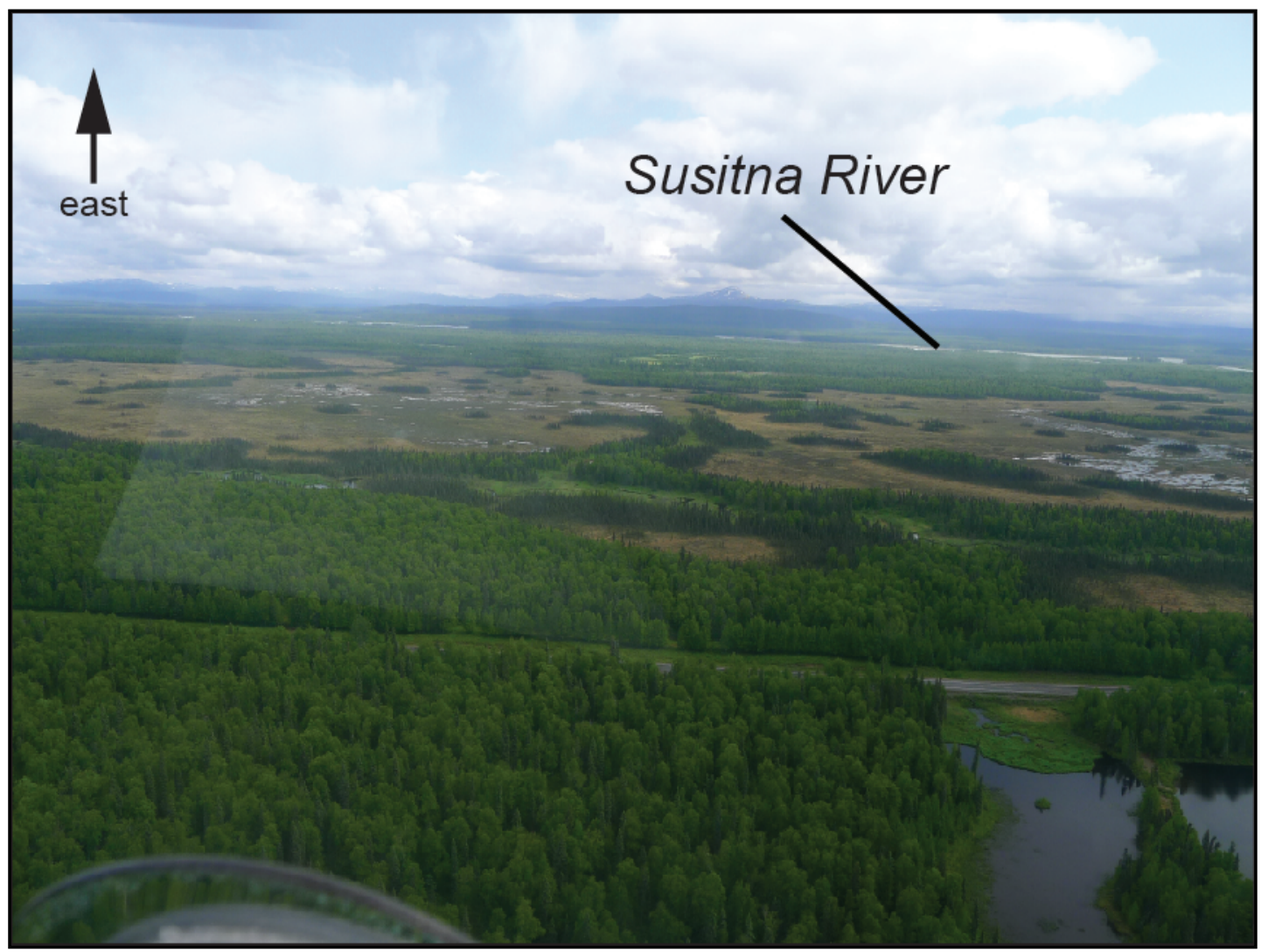

Figure 6. View along the Parks Highway north of the Susitna River bridge of ground moraine (foreground) and outwash terraces (middle ground) blanketed by eolian sand and numerous isolated sand dunes and sand dune complexes.

the corridor in this area. Erosion of the bluffs has caused geomorphically distinct and relatively recent landslides and bluff failures in the till and the underlying weathered bedrock.

In the Talkeetna C-1 Quadrangle the corridor continues north for about $4 \mathrm{mi}$ across ice-stagnation deposits and abandoned meltwater channels of sandy gravels of Elmendorf age. Beginning about $1 \mathrm{mi}$ south of the Chulitna River bridge on the Parks Highway, for about $10 \mathrm{mi}$ to the Byers Creek vicinity, the corridor crosses a complex terrain of silty till, glaciolacustrine deposits, and granular alluvium deposited by meltwaters in abandoned channels and on a broad kame terrace. Byers Creek occupies a deep former meltwater channel that was temporarily occupied by the Chulitna River when it was diverted into this preexisting deep drainageway by the latest Naptowne southward advance of
Eldridge Glacier. A coarse-grained alluvial fan has developed on the floodplain of the Chulitna River at the mouth of Byers Creek and this area could be a source of future debris-flow hazards. The Chulitna River has cut a deep, 7-mi-long gorge through the glacial deposits and underlying bedrock near Blair Lake (fig. 7). Headwall scarps of several large landslides indent the thick till of the western wall of this gorge. Upstream of the gorge, about $1.4 \mathrm{mi}$ north of the Chulitna River bridge, the Chulitna River has a broad, braided floodplain and is the cause of flooding and erosion along the western side of the corridor northward to its confluence with the Fountain River. Widespread seasonal stream icings are common along creeks that drain into the Chulitna River.

North of Byers Creek the corridor extends northeast $-20 \mathrm{mi}$ to Pass Creek south of Chulitna Butte through the southeastern corner of the Talk- 


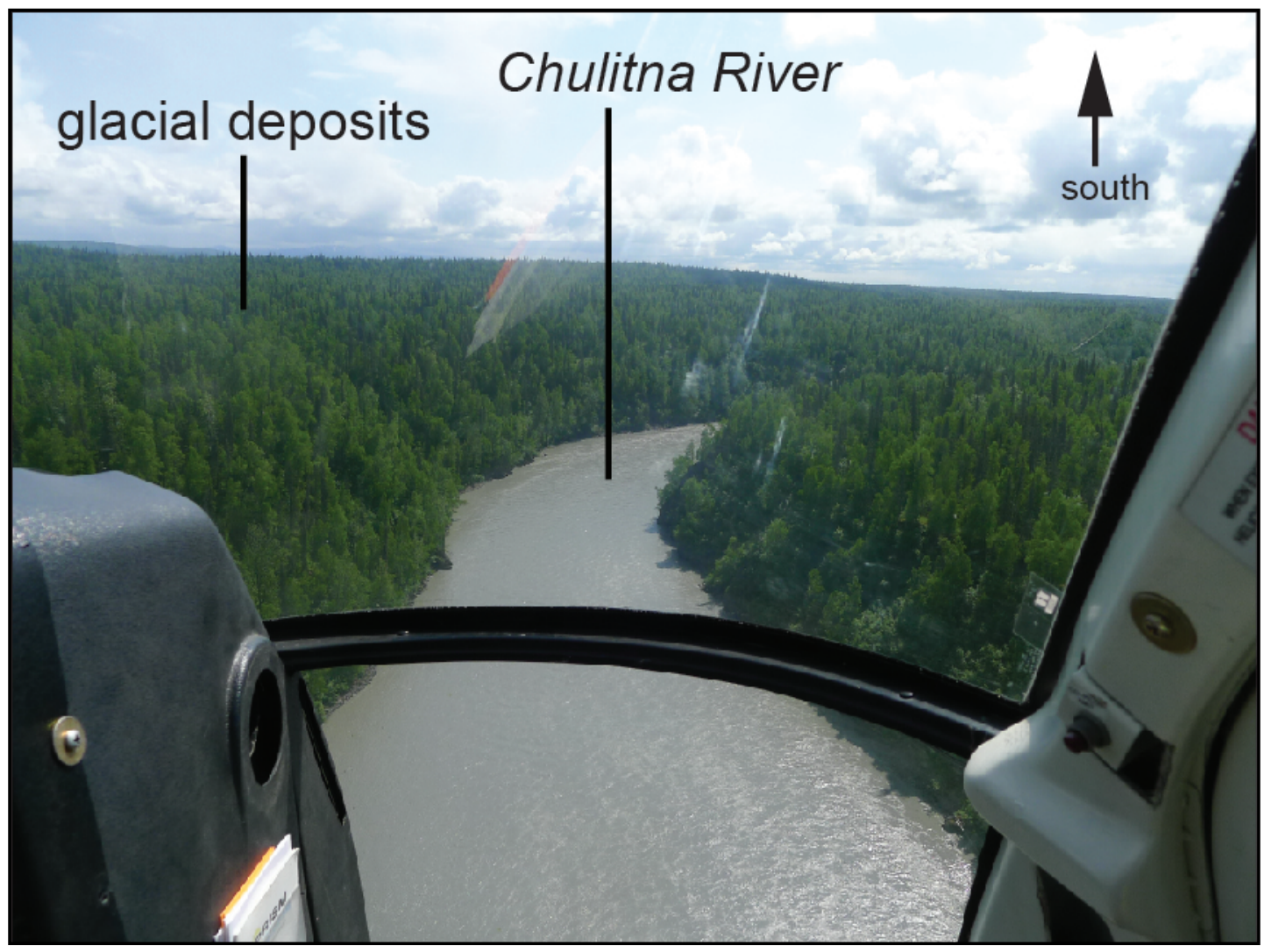

Figure 7. View to the south of the Chulitna River gorge, which is deeply incised through till, glaciolacustrine, and kame terrace deposits. Bedrock is exposed on the lower slopes of the gorge.

eetna D-1 Quadrangle and the Talkeetna Mountains D-6 Quadrangle. In this area, the corridor crosses ridges of ice-molded lodgment till and troughs of Elmendorf age cut by meltwaters of the retreating glacier that formerly occupied this broad valley. Kettles are common landforms on the pitted abandoned channels. Other common landforms in this section include basal-crevasse fills, recessional moraines, and eskers. Several large landslide complexes are present along the northwest and southeast sides of the corridor where it crosses into the Talkeetna Mountains D-6 Quadrangle. In this area the lodgment till is overlain by thick peat and related fine-grained paludal sediments and string bogs. North of Pass Creek the corridor ascends northeastward toward the northern limit of the Talkeetna Mountains D-6 Quadrangle across icescoured bedrock ridges blanketed by till (thickness unknown but generally thin).

\section{Chulitna Butte to the vicinity of Ferry} HEALY A-5, A-6, B-4, B-5, C-4, D-4, AND D-5 QUADRANGLES, 1:63,360 SCALE

In the Healy 1:250,000-scale Quadrangle, the corridor route traverses the Healy A-5, A-6, B-4, B-5, C-4, D-4, and D-5 1:63,360-scale quadrangles (sheet 1, map 3; sheet 2, map 4). From the southern boundary of the Healy A-6 Quadrangle the corridor enters the Broad Pass trough across an upland surface of thick, drumlinized, silty till that was molded by the passage of thick glacial ice during the last major (Naptowne = Riley Creek) glaciation (table 1). Bedrock exposures observed at several localities along the Chulitna River give a sense of the thickness of the overlying glacial deposits. Terraces can be observed on the west side of the Chulitna River, indicating that the corridor is largely above the modern floodplain. The route traverses this surface for $1.1 \mathrm{mi}$ north 
from the Healy A-5 Quadrangle boundary before crossing the 300-ft-deep (91.4-m-deep) Hurricane Gulch and then continues another $2.2 \mathrm{mi}$ before intersecting the valley of lower Honolulu Creek. Along valley slopes of Honolulu Creek and other small streams are weathered bedrock exposures. A $1.5 \mathrm{mi}$ section of the corridor along the southeastern side of Honolulu Creek extends across distal alluvial fan deposits associated with small streams tributary to Honolulu Creek. North of Honolulu Creek the corridor ascends once again onto the grooved upland surface. Thin, silty upland till and shallow, glacier-scoured bedrock characterize the surficial and shallow subsurface materials for the next $3.0 \mathrm{mi}$.

From Antimony Creek northeastward for $-5.5 \mathrm{mi}$, the corridor crosses alluvial fans of northwest-flowing tributaries to, and a flight of low terraces of, the East Fork Chulitna River. The alluvial fans are coarse grained and typically mantled by relatively recent debris-flow deposits. Erosion of the terrace risers by intense gullying is common. The braided channel of the East Fork Chulitna River is $-0.4 \mathrm{mi}$ wide and is deeply incised through the middle of the corridor. Cuspate landslide headscarps along the northeastern canyon wall are pervasive and nearly continuous along this section. North of the East Fork Chulitna River the corridor once again traverses thin, silty till over bedrock for $\sim 2$ mi before intersecting the Middle Fork Chulitna River and Fourth of July Creek.

In the area near Fourth of July Creek are several string bogs, and the water table is very near the surface. For the next $4 \mathrm{mi}$, the corridor follows the 0.5-mi-wide channel of the Middle Fork Chulitna River, which is characterized by braided channels, meander belts, and low, fluvial terraces. Shallow bedrock and thin till characterize the corridor between the Middle Fork Chulitna River and Fourth of July Creek. North of the Middle Fork Chulitna River and the southern limit of the Healy B-5 Quadrangle, the corridor continues to traverse the glacially grooved upland for $\sim 10.5$ mi to the margin of the Cantwell Creek floodplain. Large elongate lakes (such as Summit Lake) occupy many of the glacially scoured depressions. Near the boundary between the Healy B-5 and B-4 quadrangles several wide grooves contain low, perennially frozen, ice-rich peat mounds (palsas). Displaced signs and benchmarks on sideslopes in the alpine zone in Broad Pass, where permafrost is discontinuous to sporadic, demonstrate that vegetated sloping surfaces are subject to downslope displacements by blanket gelifluction. In this setting, annual gelifluction rates typically amount to a few inches, enough to deform shallowly anchored infrastructure elements.

From Cantwell Creek northeast for $10.0 \mathrm{mi}$, the corridor crosses low terraces and floodplain deposits of Cantwell Creek and Jack River to its confluence with the Nenana River. A change in glaciation terminology is established at Cantwell in the central Healy B-4 quadrangle where Alaska Range ice formerly flowed northward down the Nenana River valley; and south of Cantwell, flowed southward through Broad Pass toward Cook Inlet (table 1). Northeast of Cantwell the eastern side of the corridor crosses the lower colluvium-covered bedrock slopes of the Reindeer Hills, where slope processes could impact future infrastructure developments. North of the Rainbow Hills, bedrock exposures along a 2-mile section of the Parks Highway contain naturally occurring asbestos which may pose hazards to construction materials (Solie and Athey, 2015). The active Denali fault extends across the corridor $\sim 0.7 \mathrm{mi}$ south of the Nenana/Jack rivers confluence (fig. 8A). The Denali fault was the source of the $2002 \mathrm{Mw}$ 7.9 earthquake, which was associated with -211 $\mathrm{mi}$ of surface rupture with average right-lateral displacements averaging between 6.5 and $20 \mathrm{ft}$ (2 and $6.1 \mathrm{~m}$ ) (Eberhart-Phillips and others, 2003; Haeussler and others, 2004). Although the section of the fault that crosses the corridor has not generated an historic earthquake, paleoseismic studies indicate that large earthquakes occur every several hundred years (Schwartz and others, 2003). It is expected that a future earthquake on this section of the Denali fault will be associated with severe ground shaking, breaking of the ground surface, 
liquefaction of susceptible deposits, and major slope instability, including the release of dozens of massive, potentially catastrophic rock avalanches similar to those documented for the 2002 earthquake by Harp and others (2003) and Jibson and others, 2006).

North of the confluence of the Nenana and Jack rivers the corridor follows the Nenana River valley and rises onto an apron of drift and blocky, angular rubble derived from the steep southwestern and northwestern slopes of 5,800-ft-high (1,768-m-high) Panorama Mountain (fig. 8A). Large rock-avalanche and debris-flow fans have been deposited at the base of the mountain along the eastern side of the corridor. Near the northern limit of the Healy B-4 Quadrangle the corridor traverses a mile-long zone that was catastrophically impacted by a massive, ancient rock avalanche that fell from the steep upper northwestern slope of Panorama Mountain and swept across the Nenana River valley, temporarily damming the river (fig. 8B) (site 81, sheet 2, map 4, Lat./ Long. 63.4906, -148.8333). Aerial reconnaissance of upper Panorama Mountain indicates that the volcanic rocks there are pervasively jointed and extremely unstable (fig. 8C). A future strong earthquake along the Denali fault could cause release of another massive rock avalanche containing hundreds of multi-ton basalt blocks.

North of the Panorama Mountain rock avalanche, the corridor crosses low gravel and sand terraces of the Nenana River for $3.6 \mathrm{mi}$ before ascending $0.7 \mathrm{mi}$ across granular outwash alluvium of the Carlo readvance late in the Riley Creek glaciation (table 1) and traversing the alluvial fan of Carlo Creek for another $1.5 \mathrm{mi}$ (Wahrhaftig, 1958, pl. 3). The Carlo Creek fan is extremely active and subject to frequent debris flows. The corridor then rises $-200 \mathrm{ft}(61 \mathrm{~m})$ onto a pitted granular outwash terrace $(-1.5 \mathrm{mi}$ long) deposited during the Carlo readvance. For the next $6 \mathrm{mi}$ to the crossing of the Yanert Fork Nenana River (site 87, sheet 2, map 4), the corridor crosses the end moraine, proximal outwash, and a hanging delta deposited during the Carlo readvance of Riley
Creek glaciation (fig. 9). In places the till is thin with bedrock exposed west of the corridor along the Nenana River. Buried frozen, ice-rich deposits of a former ice-dammed meltwater lake cause chronic local subsidence problems in this till along the Parks Highway north of McKinley Village.

The Yanert Fork of the Nenana River is subject to periodic outburst floods produced by the sudden drainage of small ice-marginal meltwater lakes associated with Yanert Glacier (Post and Mayo, 1971). During outburst flooding, sudden rises of river stage to unusual heights, increased river velocity, and exceptionally deep scouring of the river bed should be anticipated. No bridge currently crosses this major tributary of the Nenana River.

North of the Yanert Fork the corridor crosses a nearly level terrace of granular alluvium before climbing onto and traversing glacier-scoured bedrock or thin till over bedrock for $-3.6 \mathrm{mi}$. From this irregular terrain the corridor descends slightly onto a terrace of granular outwash and across the alluvial fan of Montana Creek, which consists of granular alluvium (Wahrhaftig, 1958, pl. 3). From Montana Creek the corridor extends north across fluvial terraces of the Nenana River to the northern limit of the Healy C-4 Quadrangle, where the deeply incised Nenana River gorge begins. The active Park Road fault has displaced latest Pleistocene outwash and Holocene fluvial terraces and extends across the corridor near the Denali National Park entrance and projects eastnortheast into the gully occupied by Lynx Creek. In this area, steep bedrock sideslopes along the eastern side of the corridor are thinly covered by till and colluvium (Wahrhaftig, 1970a). Stream icings should be anticipated in this section during winter and spring where groundwater seeps emerge. Additionally, a large landslide amphitheater extending along the base of the slope for about 0.5 mi north of Lynx Creek and numerous other landslides indicate that future slope instabilities are likely in this area. 
Figure 8. A. View of Panorama Mountain in the vicinity of the Jack/Nenana rivers confluence. The location of the Denali fault is shown in red. B. Close-up view of massive Panorama Mountain rock

avalanche deposit with blocks of rock up to $20 \mathrm{ft}(6 \mathrm{~m})$ in diameter. C. View of side of Panorama Mountain, which exhibits intensely jointed and fractured volcanic rocks. The slide debris in $\mathrm{B}$ along the Nenana River is outlined by dashed black line. Views in all photographs are to the north.

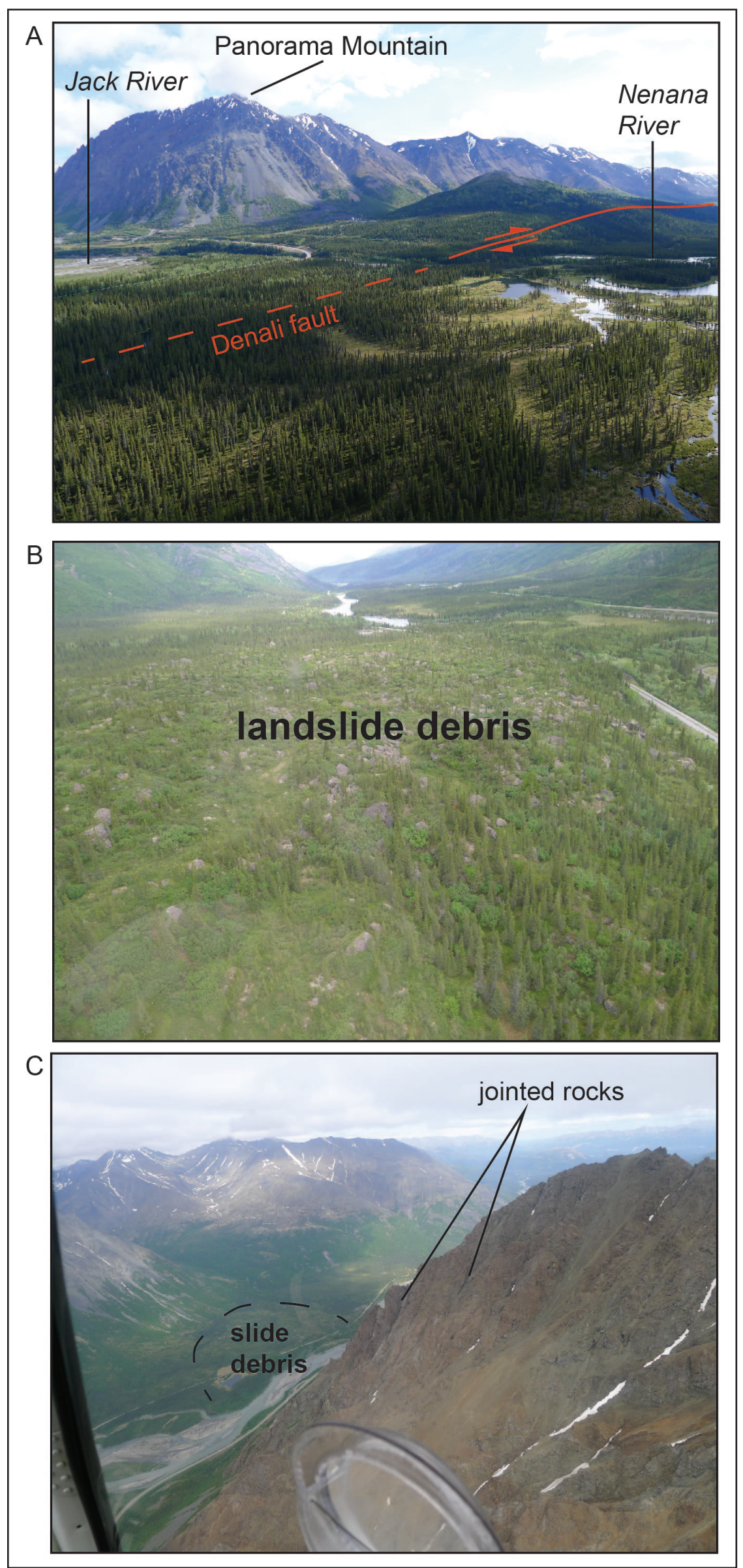




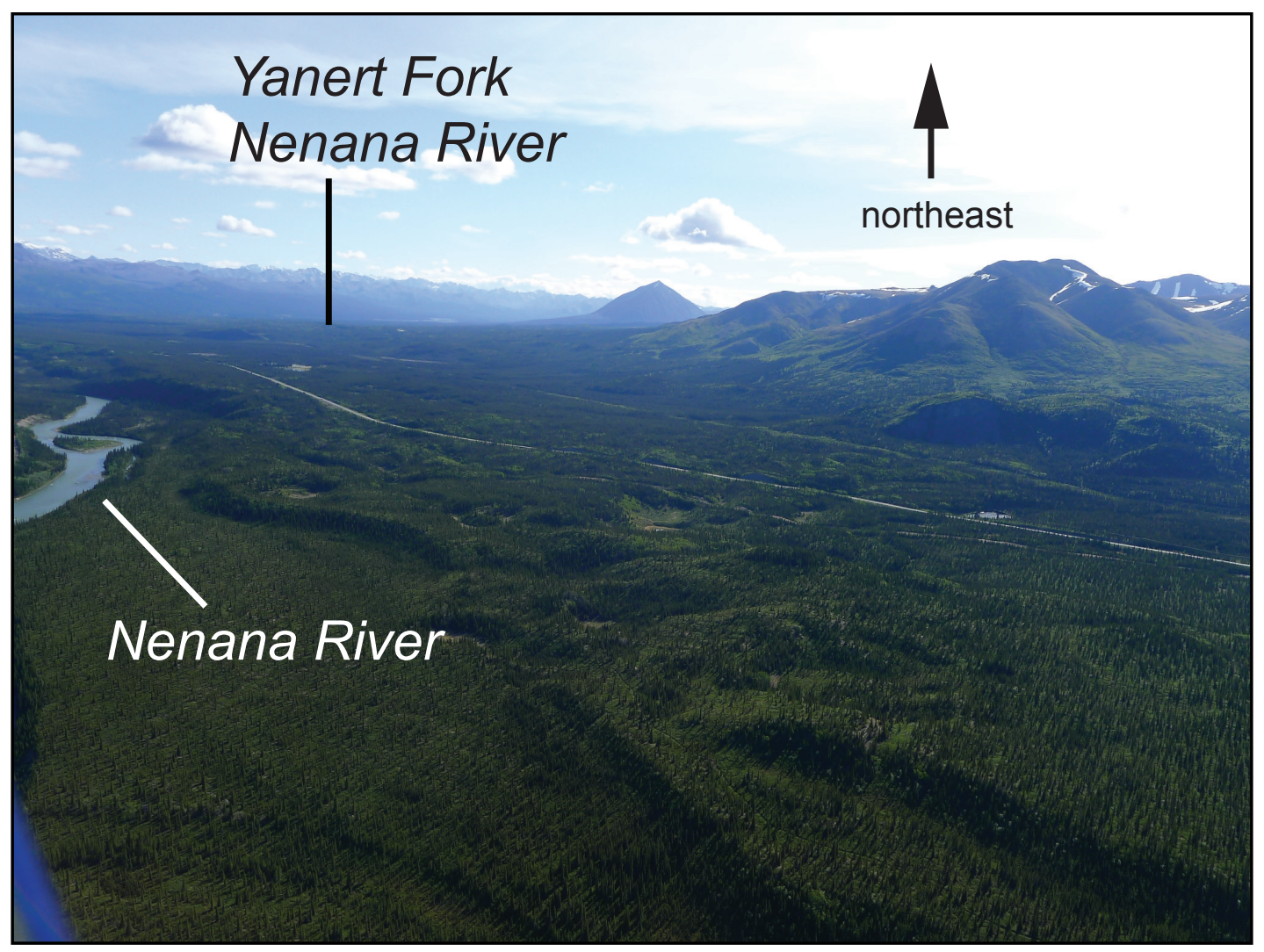

Figure 9. View to the northeast, showing irregular knob-and-kettle topography that has developed on sandy, granular till of the Riley Creek glaciation south of the Yanert Fork Nenana River. Fluvial terraces of the Nenana River can be seen on the east bank of the river (lower left of photograph).

In the Healy D-4 Quadrangle the corridor continues north-northwest along the Nenana River gorge to the vicinity of the town of Healy (fig. 10). Between Junco Creek and Iceworm Gulch, the corridor crosses the crown of a chronic landslide zone in shattered and decomposed schist bedrock associated with basalt dikes in the steep eastern wall of the Nenana Gorge. Just north of Hornet Creek the corridor traverses fine-grained sediments deposited in a lake dammed behind the massive Healy-age terminal moraine at mouth of the gorge (Wahrhaftig, 1958, pl. 2). These wet, clayey sediments have caused numerous landslides along the Alaska Railroad in the Nenana River gorge (Wahrhaftig and Black, 1958). Except for short stretches crossing granular alluvial fans and granular outwash terraces, most of the next $1.8 \mathrm{mi}$ to the crossing of the Nenana River traverses steep sideslopes of schistose bedrock. Rock avalanches and rock fall have continuously impacted the Parks Highway in this area.

North of this problematic stretch and northwest of the Nenana River gorge the corridor traverses a terrace of stable stream and alluvial-fan deposits for $-2.0 \mathrm{mi}$ and then crosses a $1.4 \mathrm{mi}$ stretch of granular till deposited during the penultimate (Healy) glaciation in the Nenana River valley (Wahrhaftig, 1970a,b). From the Healy terminal moraine (site 104a, sheet 2, map 4) near the boundary of the Healy D-4 and D-5 quadrangles, the corridor descends onto granular fluvial outwash terraces of the Healy and Riley Creek glaciations and during the Carlo Creek readvance for $1.1 \mathrm{mi}$ before crossing granular alluvium of the Dry Creek alluvial fan and floodplain for $0.8 \mathrm{mi}$ (fig. 11). Upstream of the mouth of Dry Creek west of Otto Lake, massive landslides have eroded the northwestern bluff of Dry Creek. 




Figure 10. Photographs of the Nenana River gorge. A. Steep eastern wall of the gorge near the Parks Highway bridge. B. Western wall of the gorge along the Alaska Railroad, showing active debris-flow canyons and landsliding. 


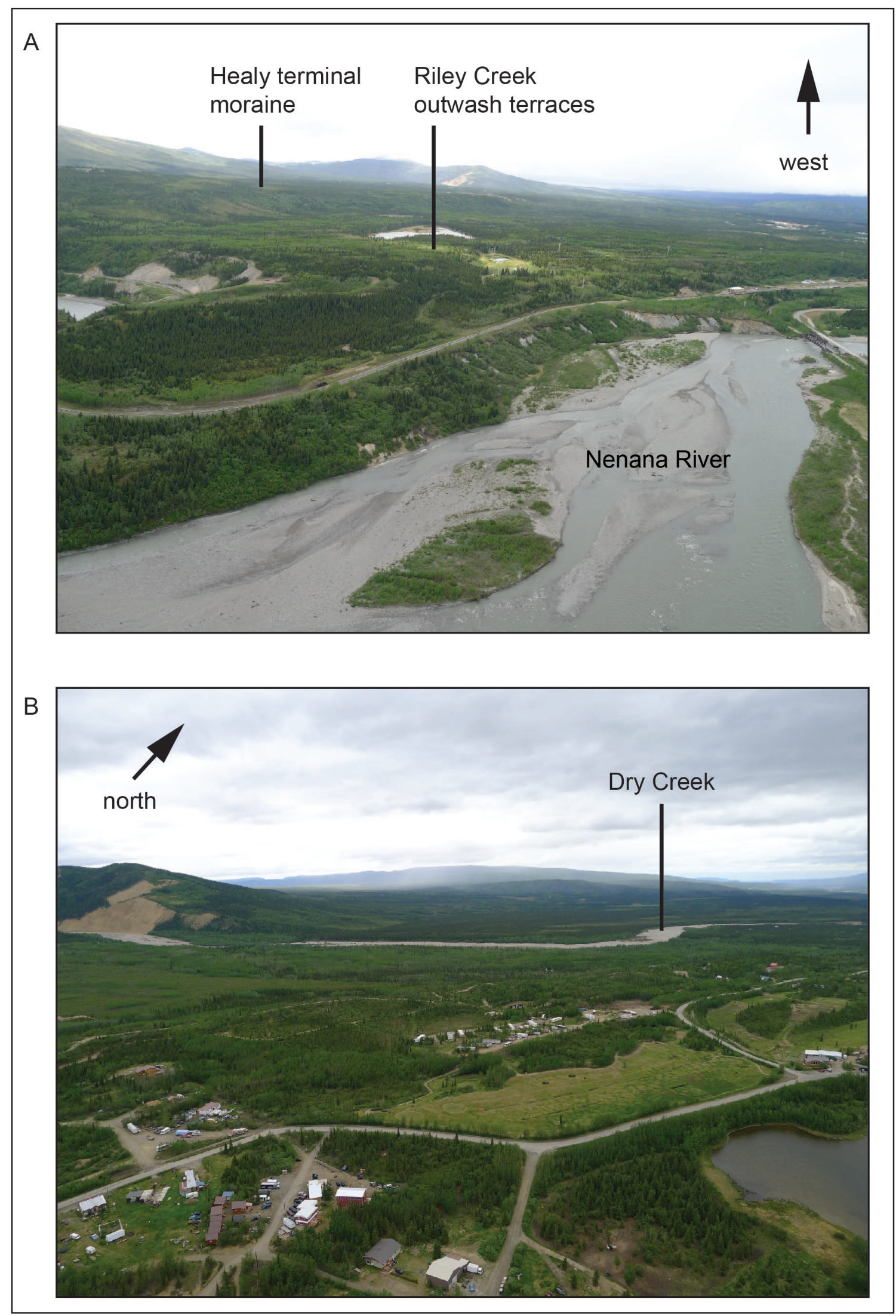

Figure 11. A. View toward west of Healy terminal moraine and Riley Creek outwash terrace surfaces in the vicinity of the town of Healy. B. View of Dry Creek alluvial valley north of the Healy terminal moraine. 
Three potentially active faults extend across the corridor in the vicinity of Healy and Lignite including the Healy, Healy Creek, and Stampede-Little Panguingue faults (Bemis, 2004, 2010; Bemis and Wallace, 2007; Bemis and others, 2012; Koehler and others, 2016). These faults have deformed Tertiary sediments and the Plio-Pleistocene Nenana Gravel formation into a series of anticlines and synclines observed to the east and west of the corridor. However, the faults have not deformed Healy and Riley Creek outwash terraces in the corridor, with the possible exception of a short scarp along the Healy fault (Bemis, 2010; Koehler and others, 2016).

North of Dry Creek the corridor follows the course of the Nenana River for $7.0 \mathrm{mi}$ across fairly thin granular stream and outwash alluvium over Tertiary bedrock (fig. 12). Outwash terraces include those associated with the Healy glaciation along the west side of the corridor and inset Riley Creek outwash surfaces. Incised into these surfaces are three small drainages (Panguingue, Little Panguingue, and Slate creeks), which produce extensive annual surface icings. Small landslides are common along the western side of the corridor through this entire section. These small failures are developed in the weathered schist (probably the Totatlanika Schist of Wahrhaftig, 1968, 1970b) and weathered Tertiary coal-bearing sedimentary rocks of the Usibelli Group (Wahrhaftig and others, 1969; Wahrhaftig, 1987) beneath the Nenana Gravel. Directly north of Slate Creek and west of the Nenana River the corridor crosses a large, chronically active landslide in the Tertiary coal-bearing sandstone (site 113 , sheet 2 , map 4). This creeping landslide is $0.5 \mathrm{mi}$ long and $0.3 \mathrm{mi}$ wide. Springs emerging from the toe of this lobate failure cause maintenance problems along the Parks Highway, which is diverted around the toe of the landslide.

The final $0.5 \mathrm{mi}$ of the corridor in the Healy Quadrangle crosses coarse-grained colluvium that originates in the granular Tertiary bedrock cropping out of the bluff above the Parks Highway to the west (Wahrhaftig, 1970b). Large glacial erratics in the upper Tertiary gravels are occasionally destabilized by slope erosion and roll downslope onto the Parks Highway in this area, causing a traffic hazard. In this area the eastern part of the corridor is characterized by gravelly floodplain alluvium of the Nenana River.

\section{Ferry to Chatanika River}

\section{FAIRBANKS A-5, B-5, C-5, C-4, AND D-4} QUADRANGLES, 1:63,360 SCALE

In the Fairbanks 1:250,000-scale Quadrangle the corridor traverses the Fairbanks A-5, B-5, C-5, C-4, and D-4 1:63,360-scale quadrangles (sheet 2, map 4; sheet 2 map 5). From the southern boundary of the Fairbanks A-5 Quadrangle the corridor proceeds $2.2 \mathrm{mi}$ north through the lower Nenana River valley across colluvium and thin terrace alluvium covering shallow, weakly cemented Tertiary bedrock to the northern wall of the slightly incised Rock Creek valley (Wahrhaftig, 1970c). In this area a tall bluff capped by relatively older alluvium of the Dry Creek terrace along the west side of the corridor and the bluff face is presently being eroded by gullies. Large granitic erratics in the dissected moraine of the Browne glaciation of early Pleistocene age (Wahrhaftig, 1958; Thorson, 1986) occasionally roll downslope and present a traffic hazard along the Parks Highway. The narrow floor of Rock Creek valley is covered by up to $-5 \mathrm{ft}(1.5 \mathrm{~m})$ of stream icing each winter and spring.

From Rock Creek to the vicinity of Rex (14 $\mathrm{mi}$ ) the corridor traverses coarse-grained fan and outwash alluvium in terraces of the penultimate (Healy) and last (Riley Creek) major glaciations in the Nenana River valley (Kachadoorian, 1960; Wahrhaftig, 1970c). Floodplain gravels and low terraces of the modern Nenana River are present along the eastern margin of the corridor. About $2.0 \mathrm{mi}$ south of Rex, the corridor enters the broad central Tanana-Kuskokwim Lowland (Wahrhaftig, 1965, p. 29), where a prominent high outwash terrace associated with the Browne glaciation is present along the eastern side of the Nenana River (fig. 13). 


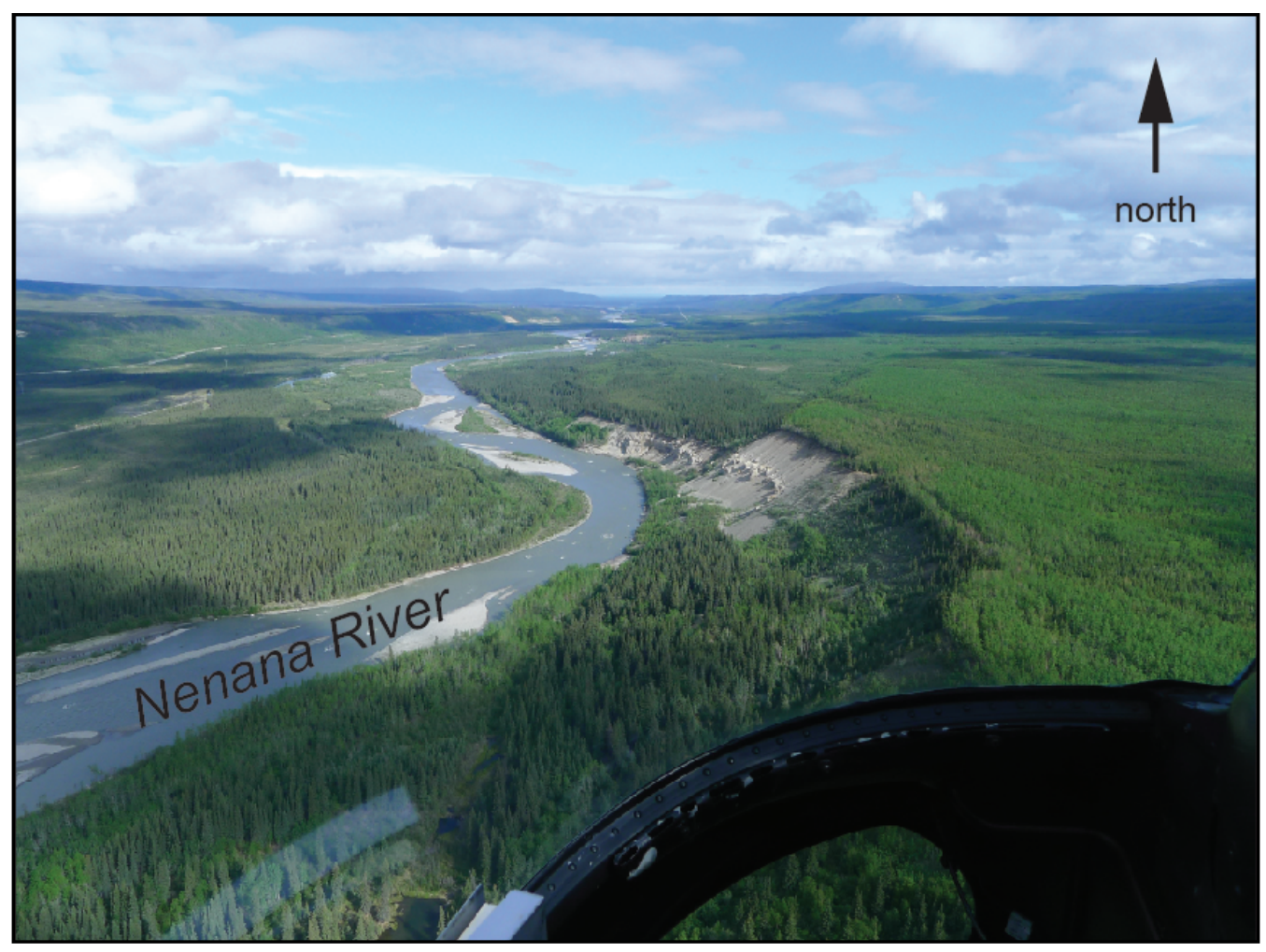

Figure 12. View toward north of thin outwash terraces over Tertiary bedrock on both sides of the Nenana River north of Dry Creek.

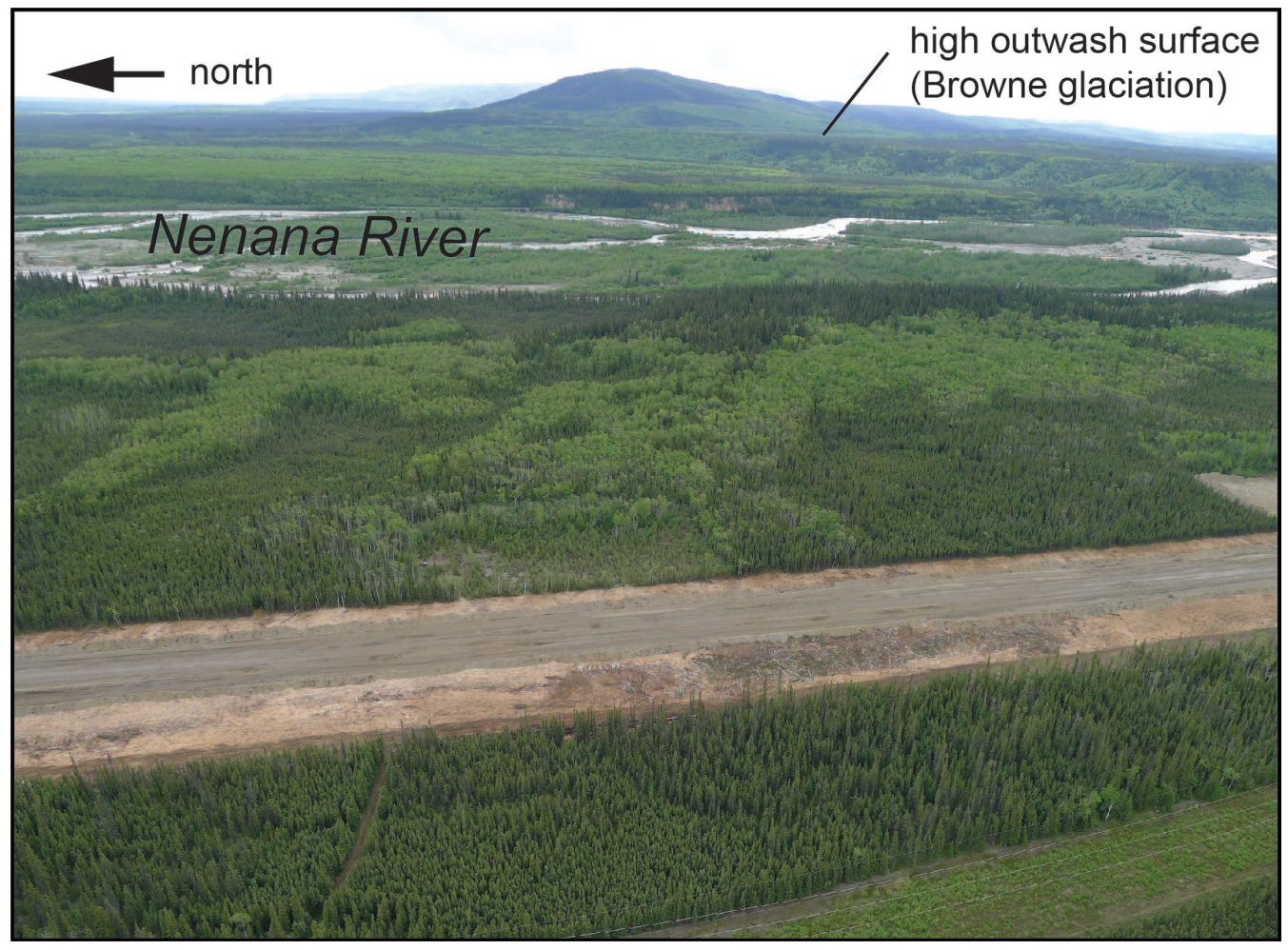

Figure 13. View toward east of high outwash terrace surface associated with the Browne glaciation along the eastern side of the Nenana River. At this location, the Nenana River transitions from the Nenana River valley to the Tanana lowland. 
The Holocene(?) active Northern Foothills thrust fault extends across the corridor about 1.3 mi south of Rex (Bemis and others, 2012; Koehler and others, 2012a). No well-defined scarp is present across the fluvial terraces, indicating that active deformation may be associated with folding in this area. Several Holocene active back thrust faults associated with the Northern Foothills thrust have been identified approximately $0.5 \mathrm{mi}$ south of the main fault and are associated with subtle southfacing scarps (Devore and others, 2012; Koehler and others, 2016).

From Rex northward, the corridor continues along the Parks Highway. It extends for a short distance across the broad, granular alluvial fan that spreads northward from the mouth of the Nenana River valley and transitions to the northeast to the stable fan surface near Clear Air Force Base. The fan is generally well drained and clasts decrease in size from cobbles near the fan apex to pebbly sands in distal areas (Kachadoorian, 1960; Rawlinson, 1987). Permafrost is generally present as sporadic masses, which are estimated to underlie 10-50 percent of the area, at depths $>20 \mathrm{ft}$ (6.1 m) (Kachadoorian, 1960).

For the next $-13 \mathrm{mi}$ north to the northern limit of the Fairbanks B-5 Quadrangle the corridor follows narrow, shallow, sandy channel fillings that discontinuously meander across a boggy lowland consisting of fine-grained deposits on the silty distal surface of broad, coalescing, piedmont fans that slope gently toward the Tanana River from the northern flank of the Alaska Range (Kachadoorian, 1960; Rawlinson, 1987; Reger, 1987). Organicrich swamp deposits are widespread in interchannel areas, and sand dunes are locally present (fig. 14). In this route segment, surface drainage ranges from excellent to poor. Although the channel sands are generally permeable, drainage is locally restricted where water tables are shallow. Processes related to annual freezing of fine-grained sediments (such as frost jacking, surface dilation, and subsidence) and thaw-induced loss of shear strength are intense in near-surface soils. Permafrost is widespread, shallow, and ice rich.

For the last $3.9 \mathrm{mi}$ south of the crossing of the Tanana River at Nenana the corridor traverses abandoned floodplains and low terraces of the lower Nenana River along the railroad route. Foundation materials are silty sands overlying pebble gravels (Reger, 1987). Across most of this segment permafrost is present in discontinuous masses, estimated to underlie 50-90 percent of the segment, with ice content estimated to be moderate (gravimetric soil moisture ranges from 25 to 50 percent by weight relative to dry soil). For $0.3 \mathrm{mi}$ south of the Tanana River the soils are interpreted to be generally unfrozen (Reger, 1987).

After crossing the Tanana River the corridor skirts steep bluffs of schistose bedrock along its eastern side for about $0.5 \mathrm{mi}$. Stability of the bedrock bluff is a concern in this area because of daylighting foliation and a history of slope failures. For the next $8.8 \mathrm{mi}$ to Little Goldstream Creek the corridor traverses low, silty sand terraces of the Tanana River characterized by abandoned meander channels, sand dunes, and numerous shallow lakes. Distal silty loess ridges and intervening gently sloping fans of retransported silt (Péwé and others, 1966; Reger, 1987) characterize the eastern side of the corridor in this section. Loess ridges are generally not perennially frozen, but permafrost is estimated to contain $>25$ percent ground-ice content in 50 percent to $>90$ percent of lowland silt fans and aprons where surface drainage is restricted by shallow-frozen ground.

In the vicinity of Little Goldstream Creek the northeast-trending Minto fault (Minto Flats seismic zone) has been imaged in seismic data and is thought to be partly responsible for the formation of the Minto Flats basin, a > 4.3-mi-deep basin filled with Tertiary sediments (Tape and others, 2015). The Minto Flats seismic zone has generated several moderate historic earthquakes. A > 3-mi-long northwest-facing topographic escarpment was interpreted by Péwé and others (1966) 


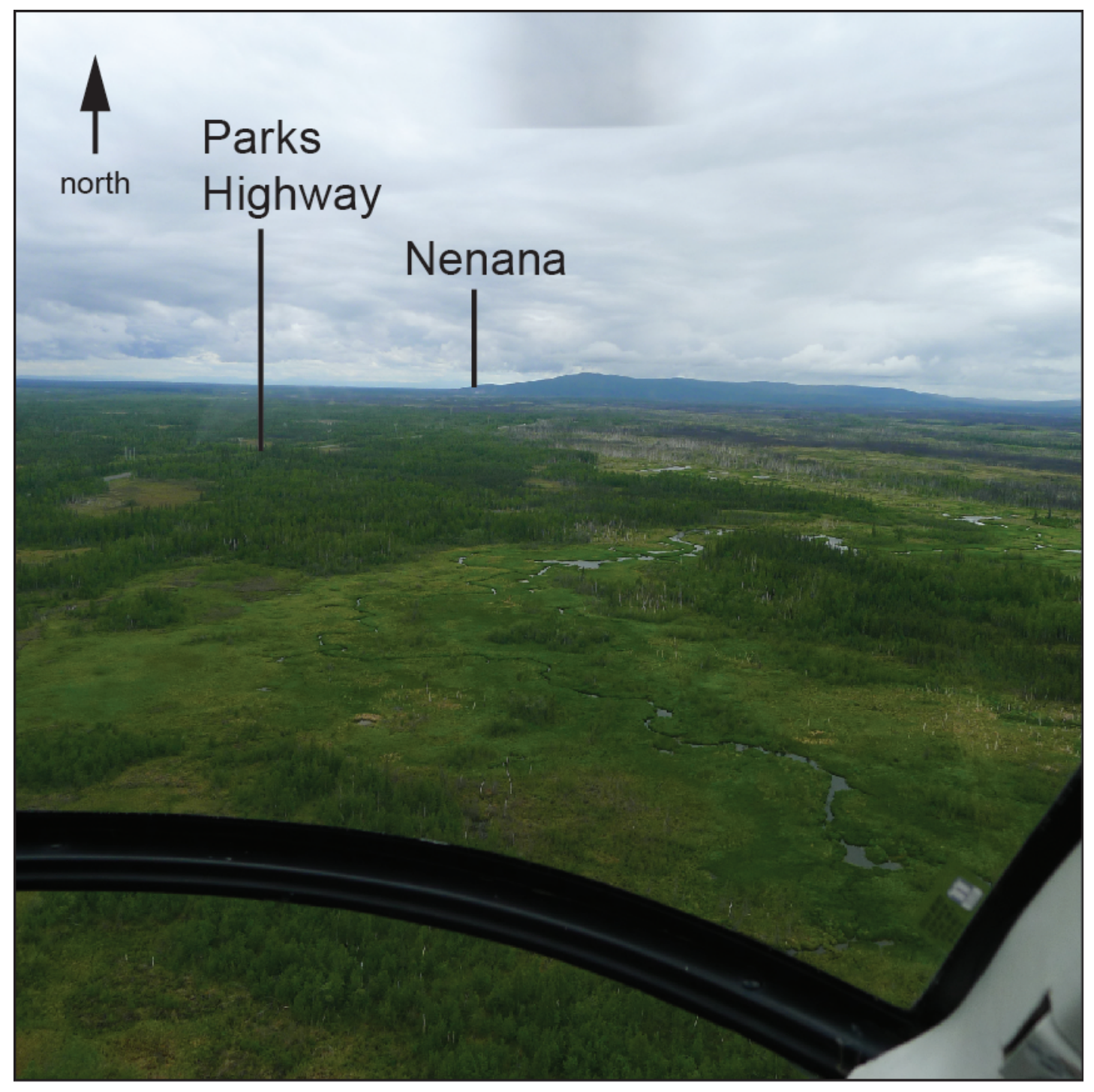

Figure 14. View toward north of organic-rich swamp deposits, sand dunes, and fine-grained channel fillings that characterize the Tanana lowland from Clear Air Force Base to the town of Nenana.

to be the surface expression of the fault. This interpretation was challenged by Page and others (1995), who suggested that the escarpment is a fluvial terrace riser of the Nenana River. This interpretation was partially confirmed by trenching across the escarpment (Koehler and others, 2016), which showed that the fluvial and loess deposits were not deformed.

From Little Goldstream Creek the corridor follows the boundary between the western YukonTanana Upland and the Minto basin of the northern Tanana-Kuskokwim Lowland (Wahrhaftig, 1965) for $5.8 \mathrm{mi}$ to the floodplain of Goldstream Creek near the abandoned settlement of Dunbar. The surface is characterized by isolated sand dunes, abandoned meander channels, and thaw lakes (fig. 15). Isolated patches of polygonal ground in this area are formed by development of ice-wedge networks in permafrost. Foundation soils in this segment are mainly alluvial or retransported silts mixed with lowland loess or sand dunes. A preliminary assessment of permafrost in the Dunbar area determined that permafrost is widespread in the lowlands and is at least $150 \mathrm{ft}(46 \mathrm{~m})$ thick (Péwé, 1949). The presence of polygonal ground, thermokarst pits, and thaw lakes demonstrates 


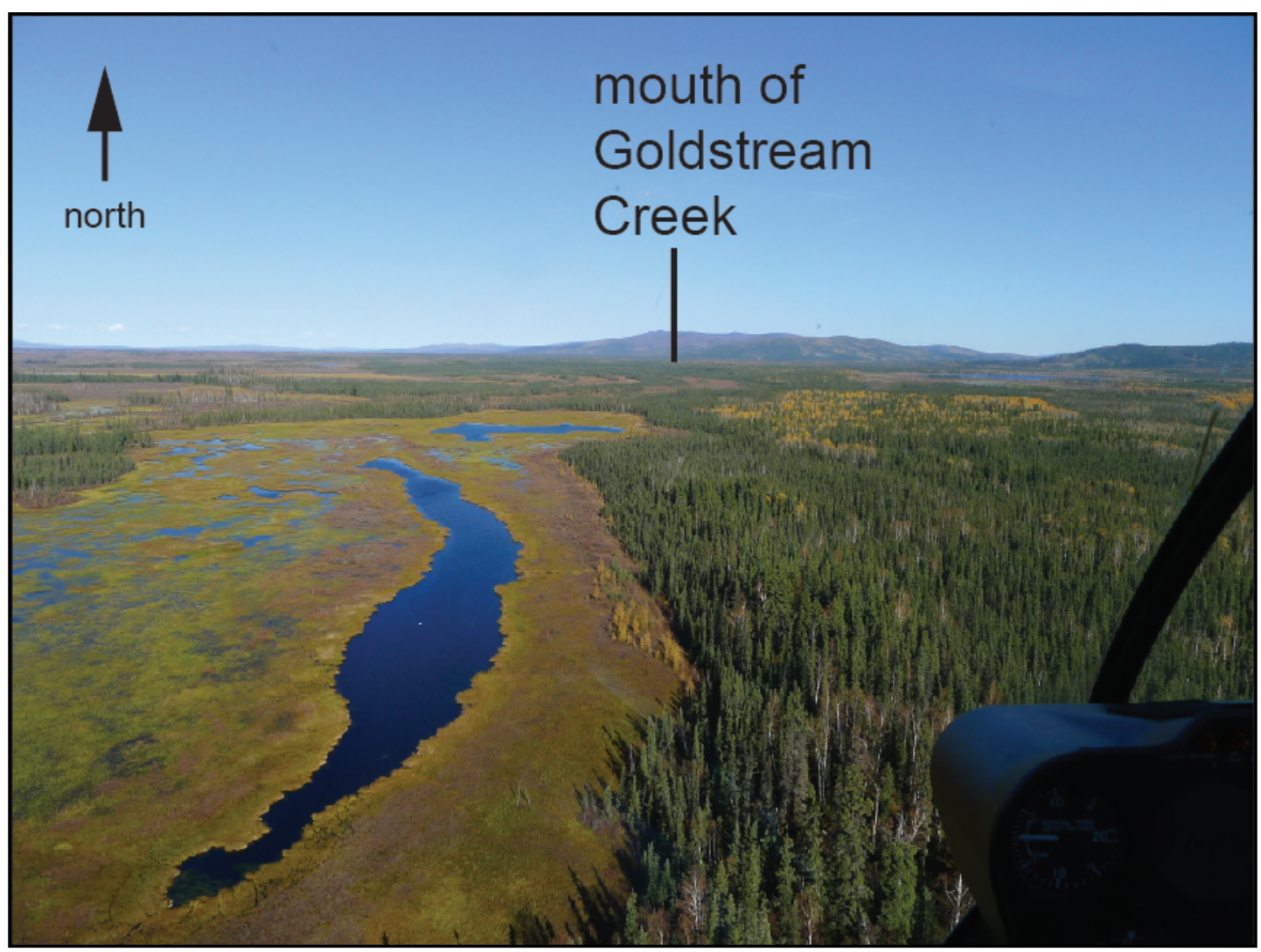

Figure 15. View toward north, showing abandoned floodplain channel of the Tanana River, isolated sand dunes, thaw lakes, and polygonal ground that characterize the corridor in the vicinity of Goldstream Creek.

that large ground-ice masses are locally present.

The next segment of the corridor crosses 1.5 mi of alluvial silts and sandy silts of the Goldstream Creek floodplain and related low stream terraces. Permafrost is discontinuous to continuous, shallow, and locally ice rich (Péwé and others, 1966). Except for the $1.1 \mathrm{mi}$ crossing of the floodplain and low terraces of the Chatanika River $0.9 \mathrm{mi}$ south of the northern boundary of the Fairbanks Quadrangle, the final $15.5 \mathrm{mi}$ of the corridor in the Fairbanks D-4 Quadrangle continue along the boundary between the Yukon-Tanana Upland and the Minto basin. In this segment, the corridor crosses low terraces of the Tanana River, the distal parts of fans of reworked loess, and scattered sand dunes. Soils are fine grained and permafrost is widespread, shallow, and locally ice rich (Péwé and others, 1966). Foundation conditions in the crossing of the Chatanika River floodplain are similar to conditions in the Little Goldstream Creek crossing.

\section{Chatanika River to Hess Creek}

\section{LIVENGOOD B-4, C-4, AND C-5 QUADRANGLES, 1:63,360 SCALE}

From the southern limit of the Livengood A-4 Quadrangle the corridor extends northward across the lowlands of Washington Creek and the Tatalina River for $7.7 \mathrm{mi}$ (sheet 2, map 6). The lowland is flat and characterized as an abandoned floodplain, as the main courses of Washington Creek and the Tatalina River meander across it and have incised channels there. Former channels on the floodplain have subdued morphology and are filled with silt and peat. The surface has numerous thermokarst ponds, lakes, and depressions; areas of polygonal ground are common. North of the Tatalina River lowland the corridor extends $5.8 \mathrm{mi}$ to the intersection of the Tolovana River lowland 
and crosses a low east-northeast-trending bedrock ridge. The ridge consists of late Proterozoic and late Paleozoic metasedimentary rocks (Weber and others, 1997) and is characterized by gentle slopes, shallow bedrock, and isolated bedrock outcrops. Surficial deposits consisting of loess and colluvium (reworked silt and organic deposits) mantle the slopes. Silt-rich alluvial fans are present along lower slopes and at the mouths of several westflowing creeks on the north side of the ridge.

North of the ridge the corridor extends along the Tolovana River lowland for $19.5 \mathrm{mi}$ to the vicinity of Livengood. Landforms along this section include open-system pingos; thermokarst ponds, lakes, and depressions; alluvial fans; and the floodplain of the Tolovana River (fig. 16). Several deep thaw basins caused by melting of massive subsurface ground ice (yedoma) are also present. Dissection of upland loess east of the corridor has resulted in the deposition of silt-rich alluvial fans.
Shallow bedrock and isolated bedrock outcrops of flysch, siltstone, and shale are present in the canyon walls of Eagle, Winter, and Shorty creeks (Twelker and others, 2016). Broad, coalescing, silt-rich fans extend up to $1.2 \mathrm{mi}$ west from the mouths of these creeks and have been incised by the south-flowing Tolovana River. The Tolovana River floodplain is characterized by wide meander belts and numerous oxbow lakes.

From the Tolovana River lowlands the corridor climbs northwestward through the Yukon-Tanana Upland, generally following the Dalton Highway, where ridge crests and hilltops stand in relief up to $\sim 1,600 \mathrm{ft}(-488 \mathrm{~m})$ above stream valley bottoms. Bedrock exposures through this region are highly weathered (Mertie, 1937). The initial $2.7 \mathrm{mi}$ segment of this route crosses lower Paleozoic to latest late Proterozoic bedrock beneath a thin blanket of silty upland loess. The bedrock includes the Amy Creek assemblage, a

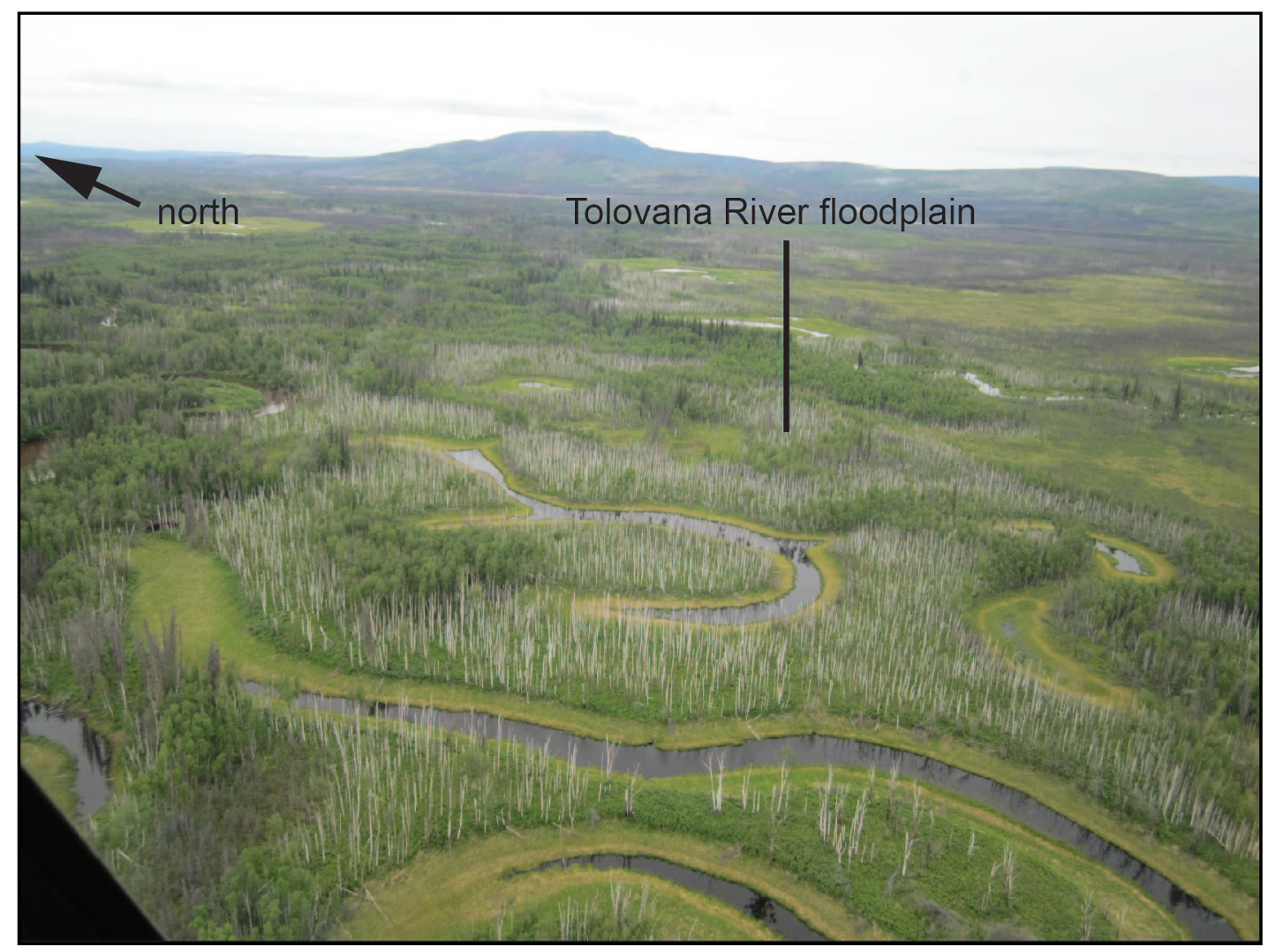

Figure 16. Aerial view of the Tolovana River floodplain south of Livengood, where typical landforms include open-system pingos, thermokarst ponds, and abandoned oxbow meanders. 
suite of dolostone, siliceous mudstone, and chert with minor metabasalt (Athey and others, 2004) which has been shown to have a medium to high likelihood of naturally occurring asbestos (Solie and Athey, 2015). This assemblage is in fault contact with the Livengood Dome Chert of Ordovician age. Weber and others (1992) interpret the abrupt contact between the bedrock packages to be a north-vergent thrust fault, and Athey and others (2004) interpret it to be an east-northeasttrending right-lateral strike-slip fault; however, there is no evidence for Quaternary activity on these structures.

For the next $2.2 \mathrm{mi}$ to the crossing of Lost Creek the Livengood Dome Chert is present beneath a thin loess blanket on slopes and as linear outcrops along east-northeast-trending ridge crests. In this short section, swales and lower sideslopes traversed by the corridor are underlain by subparallel ridges of thick, ice-rich, dissected, retransported silt and lowland loess. Remnants of oxidized stream gravels of Tertiary and Quaternary age form isolated benches on the walls of Lost Creek valley (Waythomas and others, 1984; Weber and others, 1992). Locally, feldspars are reduced to clays in these bench gravels, and quartz clasts are pitted and frosted.

North of Lost Creek the corridor gradually rises for $0.8 \mathrm{mi}$ across an apron of ice-rich, retransported silt and lowland loess before climbing a ridge of shallow Livengood Dome Chert for 0.9 mi to a prominent ridge crest of the same bedrock. The surface mantling loess is intensely rilled and gullied in this area. North of the ridge crest, the corridor crosses upper, southwest-facing sideslopes over frozen upland loess containing considerable ground ice for $1.2 \mathrm{mi}$ to a 0.2 -mi-wide ridge that is shallowly underlain by the Wickersham shale, a complex package of argillite, phyllite, quartzite, and sandstones of earliest Cambrian(?) to late Proterozoic age (Weber and others, 1992). From here to the Ray River drainage (described later) the frozen upland loess was deposited during past glaciations by katabatic winds sweeping south- ward out of the southern Brooks Range across the Yukon River lowlands to the north (Williams, 1962; Muhs and Budahn, 2006).

The corridor gradually descends northwestward down a dissected apron of frozen, ice-rich loess for $1.5 \mathrm{mi}$ before crossing the Victoria Creek strand of the Tintina fault (Weber and others, 1992; Plafker and others, 1994). No detailed studies on the fault's Quaternary history have been performed; however, no tectonic geomorphology has been observed in the corridor that is indicative of active deformation. North of the fault the deeply buried bedrock is composed primarily of sedimentary members of the Rampart Group, including argillite, chert, fine-grained graywacke sandstone, shale, and limestone, with some associated intrusive and extrusive mafic igneous rocks, all of Triassic to Mississippian age (Weber and others, 1992).

Northwest of the Victoria Creek fault the corridor traverses a lowland of thick, frozen loess with numerous small, open-system pingos and deep yedoma depressions (Kreig and Reger, 1982; Shur and others, 2010). The nearby Trans-Alaska Pipeline System (TAPS) is elevated in this area, indicating that the permafrost is ice rich. For the next $0.8 \mathrm{mi}$ the corridor rises slightly and crosses a low bedrock ridge with a thin loess cover before descending into the valley of Erickson Creek. There the nearby TAPS pipeline is buried in bedrock. The dominant lithology in the section is Triassic to Mississippian mafic intrusive and extrusive igneous rocks of the Rampart Group (Weber and others, 1992). For the next $0.4 \mathrm{mi}$ the corridor crosses the frozen floor of Erickson Creek valley, which is underlain by thick, ice-rich, retransported silt and lowland loess containing yedomas and crosses Erickson Creek before climbing onto a low ridge and passing by a series of low bedrock knobs separated by thin lowland loess for $0.5 \mathrm{mi}$ (Kreig and Reger, 1982; Kanevskiy and others, 2012). For the next $2.6 \mathrm{mi}$ the corridor passes over thick, ice-rich, frozen loess across shallow, gently sloping valleys separated by low ridges of deeply buried 
bedrock. Upper slopes of the thick fills are extensively dissected by parallel to subparallel, pinnate thaw gullies (Kreig and Reger, 1982, p. 46-49). The next $2.1 \mathrm{mi}$ takes the corridor along the crest of a shallowly buried ridge of Triassic to Mississippian mafic intrusive and extrusive rocks of the Rampart Group (Weber and others, 1992). The nearby TAPS pipeline is buried in this section. The $0.6 \mathrm{mi}$ descent to the floor of Hess Creek valley is across a frozen apron of ice-rich, dissected, retransported silt and lowland loess.

The discontinuously frozen floodplain of complexly meandering Hess Creek is crossed for $1.1 \mathrm{mi}$. Older parts of the valley bottom are covered by 4-10 ft $(1.2-3 \mathrm{~m})$ of generally frozen organic silt and silty sand alluvium over perennially frozen sand and gravel alluvium (Kreig and Reger, 1982, p. 50-52). Generally unfrozen gravel and sandy gravel alluvium at and near the surface are associated with active stream channels.

\section{Hess Creek to Yukon River}

\section{LIVENGOOD C-5 AND D-5 QUADRANGLES, 1:63,360 SCALE}

From the northern margin of the Hess Creek valley, the corridor continues northwest for $4.3 \mathrm{mi}$, ascending a gently sloping apron of ice-rich, retransported loess and lowland loess before traversing a plateau of low, rolling hills (sheet 3, map 7). The loess cover is intensely gullied on mid and lower slope areas and thin on bedrock ridges. The upland loess is perennially frozen and ice rich, which has resulted in the elevated mode of the nearby TAPS pipeline. The underlying bedrock in this section consists of mixed igneous and sedimentary rocks of the Rampart Group that may host naturally occurring asbestos (Solie and Athey, 2015). Valley bottoms are filled with thick, coalesced silt fans and ice-rich, retransported upland loess and have scattered open-system pingos. Next, the corridor continues $9 \mathrm{mi}$ to the Isom Creek valley across low bedrock ridges thinly covered by frozen upland loess. Shallow bedrock includes mixed igneous and sedimentary units of the Rampart Group and a sequence of conglomerates, graywacke sandstones, siltstones, shales, and coal containing a temperate flora of Eocene age; interlayered with metabasalts and fine-grained volcanic tuffs (Weber and others, 1992). Stream valleys between ridges contain ice-rich, retransported silt and loess. The $0.6 \mathrm{mi}$ gradual descent into Isom Creek traverses a thick apron of frozen, ice-rich, retransported loess and upland loess.

The Tozitna fault, a right-lateral, strike-slip strand of the Tintina fault to the east that cuts the Rampart Group (Weber and others, 1992), is buried by a thick fill of frozen, ice-rich, retransported silts and upland loess in the generally linear Isom Creek valley. Well-defined tectonic landforms along the fault are not observed on the lidar data; however, no detailed studies of the Quaternary history of the fault have been performed.

North of Isom Creek the corridor crosses silty, ice-rich valley fill of retransported silt and frozen loess for $-1 \mathrm{mi}$ before climbing northwestward for $1.2 \mathrm{mi}$ across a fairly steep slope of Rampart Group volcanics, thickly covered by frozen, icerich upland loess. From the crest of the ridge, the corridor extends for $-5 \mathrm{mi}$ across frozen, ice-rich upland loess and retransported silt containing several deep yedoma depressions on the northfacing slope of the Yukon River valley. The northfacing slope exhibits deeply eroded channels characterized by dendritic gully networks that have incised the frozen upland loess and underlying bedrock (fig. 17A). The bluff along the southern side of the Yukon River is more than $150 \mathrm{ft}$ (46 $\mathrm{m})$ high and is characterized by numerous thaw gullies, thaw basins, and large landslide scarps (Koehler and others, 2013c). A large landslide near the southern abutment of the Yukon River bridge occurred in late fall 2012 (fig. 17B). This slide was more than $90 \mathrm{ft}(27.4 \mathrm{~m})$ wide and $220 \mathrm{ft}(67.1 \mathrm{~m})$ long. Field studies to determine the mechanism of sliding concluded that the slide was a frozen blockglide failure that transitioned downslope to a debris slide (Koehler and others, 2013c). Koehler and others (2013c) determined that the main causative 


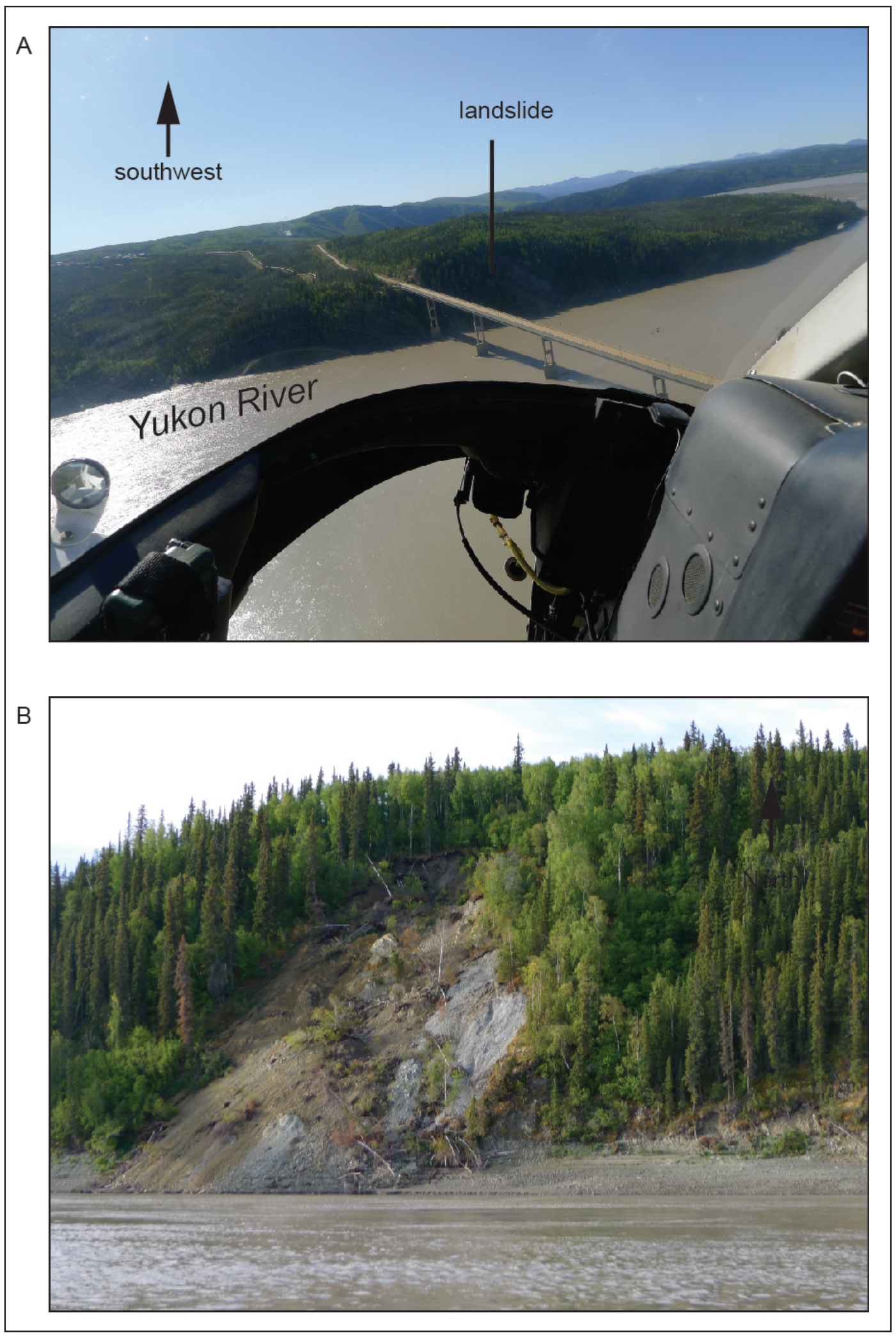

Figure 17. A. View toward southwest of southern bluff of the Yukon River. Hills slope gently to the north to the crest of the bluff and exhibit yedoma, gullies, and landslide headscarps. B. View of the 2012 landslide directly west of the Yukon River bridge. Location of slide is shown in A. 
factors were the high density of fractures, joints, and shear zones in the underlying bedrock and tensional forces in the overlying frozen colluvium and loess, which produced open transverse cracks and deformed, nonfoliated ice-wedge fillings.

\section{Yukon River to Fort Hamlin Hills} LIVENGOOD D-6 QUADRANGLE, 1:63,360 SCALE

North of the Yukon River along the Dalton Highway the corridor traverses a low, fine-grained, frozen, ice-rich fluvial terrace for $0.5 \mathrm{mi}$ to the base of a short, steep, flood-carved scarp cut into an older apron of ice-rich, retransported silts and lowland loess pocked with numerous large yedoma depressions (fig. 18A). Other signs of icerich permafrost are polygonal ground and thermokarst gullies. Along the southwestern side of the corridor is the Ray River lowland, a slackwater basin that was inundated during colossal middle Pleistocene floods of the Yukon River (fig. 18B). Field evidence indicates that the floods reached as high as 300 to $-460 \mathrm{ft}(91$ to $-140 \mathrm{~m})$ above the modern Yukon River. Flood silts and sands are at least $100 \mathrm{ft}(30.5 \mathrm{~m})$ thick in the lowland and are perennially frozen and at least locally ice rich, as indicated by the presence of numerous thermokarst ponds, lakes, and basins. The floods occurred in response to the overflow of Glacial Lake Old Crow at the head of the Porcupine River and the sudden drainage (outbursting) into Yukon River tributaries of glacier-impounded lakes in the Yukon-Tanana Upland (Froese and others, 2003; Thorson, 1989). Meandering finegrained floodplains follow the Ray River across the bottom land to the Yukon River junction.

From the back edge of the fluvial terraces along the north side of the Yukon River northwestward for $4.2 \mathrm{mi}$ the corridor traverses a finegrained alluvial surface containing large yedoma depressions. It then extends across the margin of a fine-grained complex of fans and aprons composed of alluvium and colluvium shed from volcanic and sedimentary terranes of the Rampart Group in the southern Fort Hamlin Hills to the northeast. The complex is perennially frozen and ice rich, and the TAPS pipeline is elevated on thermal verticalsupport members through this area.

In the next $-5 \mathrm{mi}$ to the western edge of the Livengood D-6 Quadrangle, the corridor extends across a gently irregular alluvial apron surface dissected by several shallow valleys of southwest-flowing tributaries of the Ray River. Ice-rich, perennially frozen silts underlie this surface, and the nearby TAPS pipeline is elevated. The corridor crosses several narrow, northeast trending ridges of Rampart Group volcanic and sedimentary rocks that are thinly covered by loess and exhibit scattered gelifluction lobes. Stream valleys between these ridges are filled with icerich, retransported silt and lowland loess.

\section{Fort Hamlin Hills to Jim River}

TANANA D-1 AND BETTLES A-1, B-1, B-2, C-2, D-1, AND D-2 QUADRANGLES, 1:63,360 SCALE

Beginning at the southern edge of the Bettles A-1 Quadrangle to No Name Creek, a distance of $8.4 \mathrm{mi}$, the corridor extends across the western margin of the Fort Hamlin Hills (fig. 19A). The hills are composed of the Rampart Group, a sequence of weathered Mississippian to Triassic volcanic and cherty shale-argillites that has been intruded by Cretaceous granitic plutons (Patton and Miller, 1973; Chapman and others, 1982; Weber and others, 1992). Depth of bedrock weathering is $\geq 5 \mathrm{ft}(\geq 1.5 \mathrm{~m})$. Upland summits and slopes are covered by a discontinuous blanket of colluvium derived by frost weathering of the bedrock. About $1 \mathrm{ft}(0.3 \mathrm{~m})$ of loess blankets bedrock and colluvium on the upland, and retransported silt mixed with lowland loess forms fine-grained aprons on middle and lower slopes. Polygonal ground and yedoma basins are also present in the lowlands. Ancient high-level terraces on both sides of $\mathrm{No}$ Name Creek are capped by $>50 \mathrm{ft}(>15.2 \mathrm{~m})$ of granitic sand and gravel (grus wash) derived from the weathering of local granitic bedrock (Kreig and Reger, 1982, pl. 14) (fig. 19B). The retransported grus overlies basalt flows of late Tertiary or early 


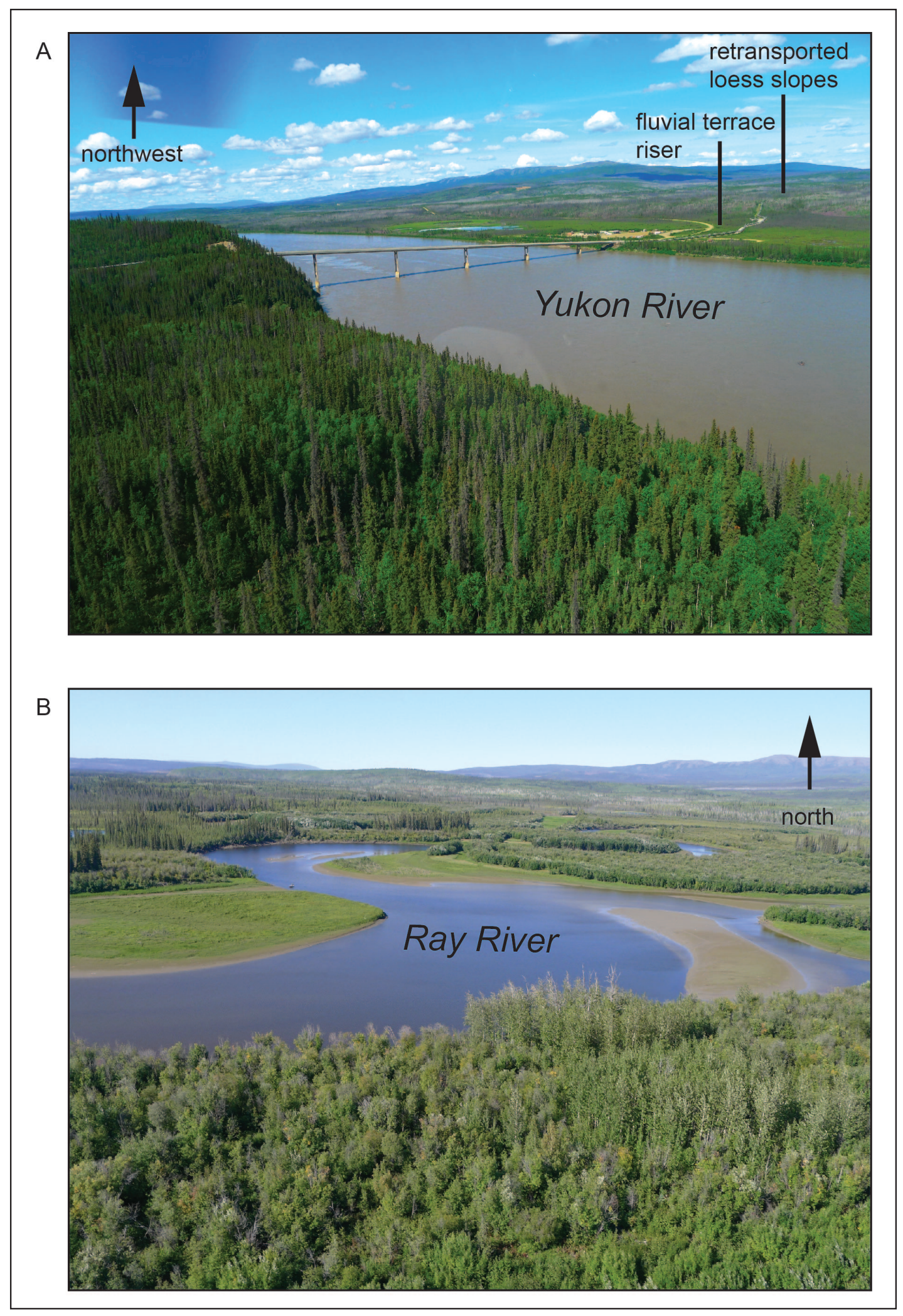

Figure 18. A. View showing low slopes of ice-rich, retransported loess directly north of the Yukon River bridge. B. Ray River lowland in the vicinity of its confluence with the Yukon River. 


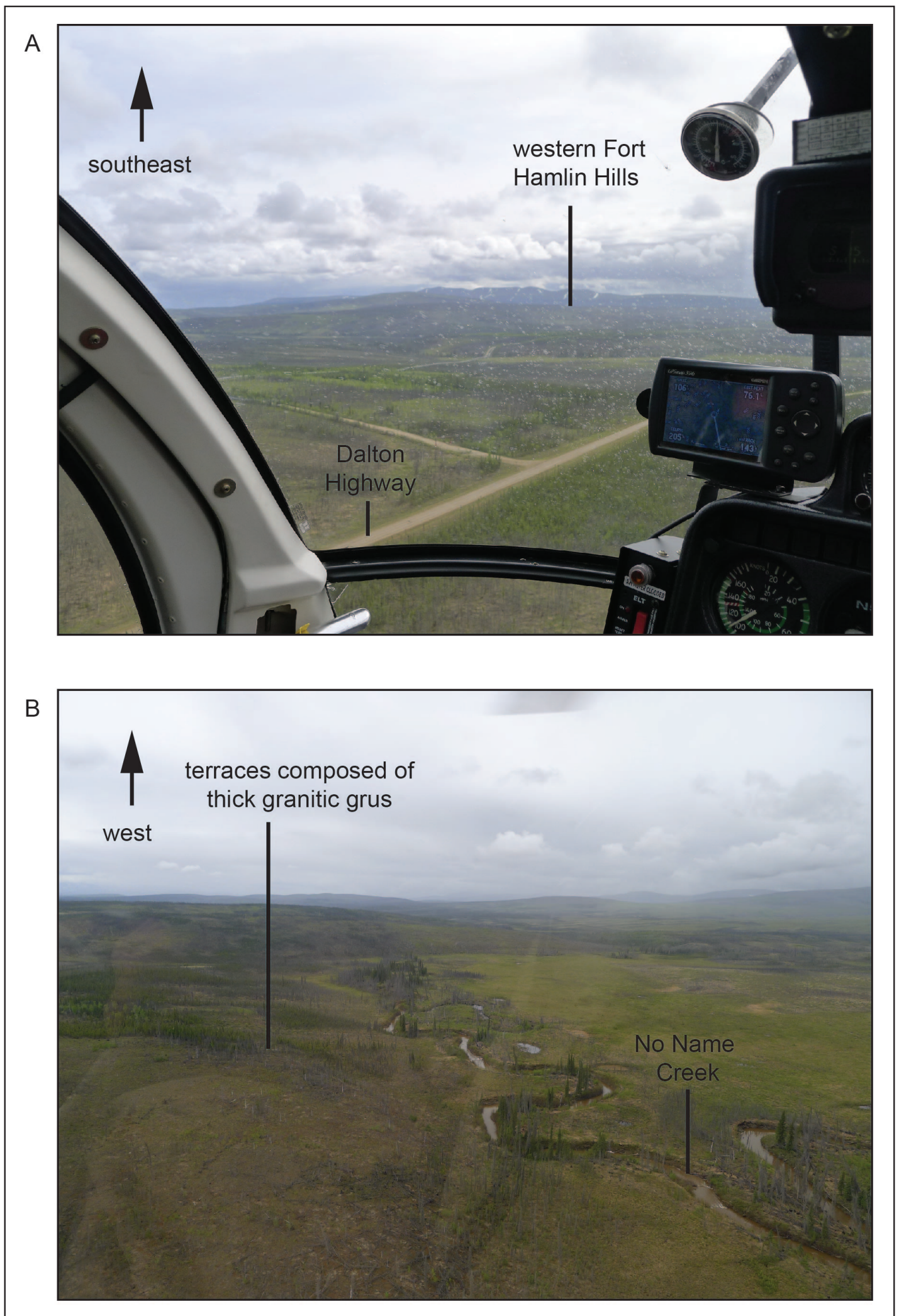

Figure 19. A. View toward southeast of the western Fort Hamlin Hills along the Dalton Highway. B. View of No Name Creek west of the Dalton Highway. High-level terraces on both sides of No Name Creek valley are underlain by thick deposits of granitic grus. 
Pleistocene age in these ancient terraces (Patton and Miller, 1973).

After crossing the ancient high terrace on the north side of No Name Creek, the corridor gradually ascends a 5.8mi grade northward across a broad, fine-grained colluvial apron. Borings demonstrate that the colluvium is thickest ( $>50 \mathrm{ft}[>15.2 \mathrm{~m}]$ ) on lower to middle slopes and gradually thins to 4-16 ft (1.2-5 m) on higher slopes (Kreig and Reger, 1982, pl. 15). For the next $4.0 \mathrm{mi}$ the corridor extends across a ridge of late Paleozoic to middle Mesozoic mafic volcanic and intrusive rocks and descends down the northwestern slope of a small drainageway into a basin containing mounds up to $70 \mathrm{ft}(21.3 \mathrm{~m})$ high west of the Dalton Highway (Kreig and Reger, 1982, pl. 15). The mounds are composed of frozen silt and angular gravel brought into the basin from the surrounding slopes by gravity-driven slope processes. The complex hummocky terrain is likely the product of aggrading permafrost in the basin fill (Kreig and Reger, 1982, pl. 15). Borings drilled in 1972-1974 demonstrate that the ridge is mantled by $2-6 \mathrm{ft}(0.6-1.8 \mathrm{~m})$ of pebbly and cobbly fine-grained colluvium over $5-25 \mathrm{ft}$ (1.5-7.6 m) of weathered late Paleozoic and early to middle Mesozoic mafic volcanic and plutonic rocks and Paleozoic schists (Patton and Miller, 1973).

In the next $-4.5 \mathrm{mi}$ the corridor crosses the drainage basins of two branches of West Fork Dall River and skirts an intervening ridge of Cretaceous granitic rocks (Hot Springs pluton of Patton and Miller, 1973). Silty colluvial fills in the drainages are $\geq 50 \mathrm{ft}(\geq 15.2 \mathrm{~m})$ thick. For about $5 \mathrm{mi}$ farther north to the vicinity of Olsons Lake basin, the corridor crosses higher surfaces containing residual outcrops (tors) of weathered granitic bedrock (fig 20A). The subsurface matrices of silty, sandy grus have been stripped by subsurface piping and retransported to form sandy aprons on lower slopes. Microrelief features indicate that solifluction is a significant transporting agent (Kreig and Reger, 1982, pl. 16). Borings in 1971 and 1975 demonstrate that the sandy skirt beneath the higher granitic slopes is $7-14 \mathrm{ft}(2.1-4.3$ m) thick. Surface characteristics of Olsons Lake basin include thaw lakes and polygonal ground (fig. 20B).

Late Paleozoic to middle Mesozoic mafic volcanic and ultrabasic igneous rocks covered by colluvium underlie the next $3.6 \mathrm{mi}$ of the route to the short crossing of the Kanuti River. These rocks have a high likelihood of hosting naturally occurring asbestos, a potential hazard to sampling, testing, and use of construction materials (Solie and Athey, 2015). Weathered bedrock is buried by 8 to $>50 \mathrm{ft}(2.4$ to $>15.2 \mathrm{~m})$ of fine-grained colluvium. About a mile north of Kanuti River, the corridor intersects the margin of a Cretaceous granitic pluton (Patton and Miller, 1973). The surface of the pluton for the next $1.5 \mathrm{mi}$ is littered with residual granitic blocks in a sandy matrix, and the lower slopes are skirted by a sandy colluvial grus apron. Ridge crests in this area contain prominent tors (fig. 21).

From the granitic upland the route crosses a wedge of Paleozoic mafic volcanic rocks and traverses that landscape for $2.9 \mathrm{mi}$ to upper Fish Creek, where the corridor enters a metamorphic terrane of Paleozoic schists and metagraywackes (Patton and Miller, 1973). Silty colluvium on upper slopes is $3-10 \mathrm{ft}(0.9-3 \mathrm{~m})$ thick, on middle slopes is $4-7 \mathrm{ft}(1.2-2.1 \mathrm{~m})$ thick, and on lower slopes is $5-43 \mathrm{ft}(1.5-13.1 \mathrm{~m})$ thick over 5-15 $\mathrm{ft}(1.5-4.6 \mathrm{~m})$ of weathered bedrock (Kreig and Reger, 1982, pl. 17). Steep north-facing slopes underlain by shallow bedrock are covered with turf-covered soil lobes as a result of downslope soil flow and frost creep (solifluction) under the influence of gravity. Surface measurements indicate that annual solifluction rates are $0.4-0.8 \mathrm{in} /$ yr $(1-2 \mathrm{~cm} / \mathrm{yr})$ in the Fish Creek area (Kreig and Reger, 1982, pl.17). This metamorphic terrane is traversed for $10.3 \mathrm{mi}$ to the crossing of South Fork Bonanza Creek.

On the north side of South Fork Bonanza Creek, the corridor crosses a Cretaceous pluton (Bonanza Pluton of Patton and Miller, 1973) for $5.5 \mathrm{mi}$. Weathering of the jointed granitic bedrock 


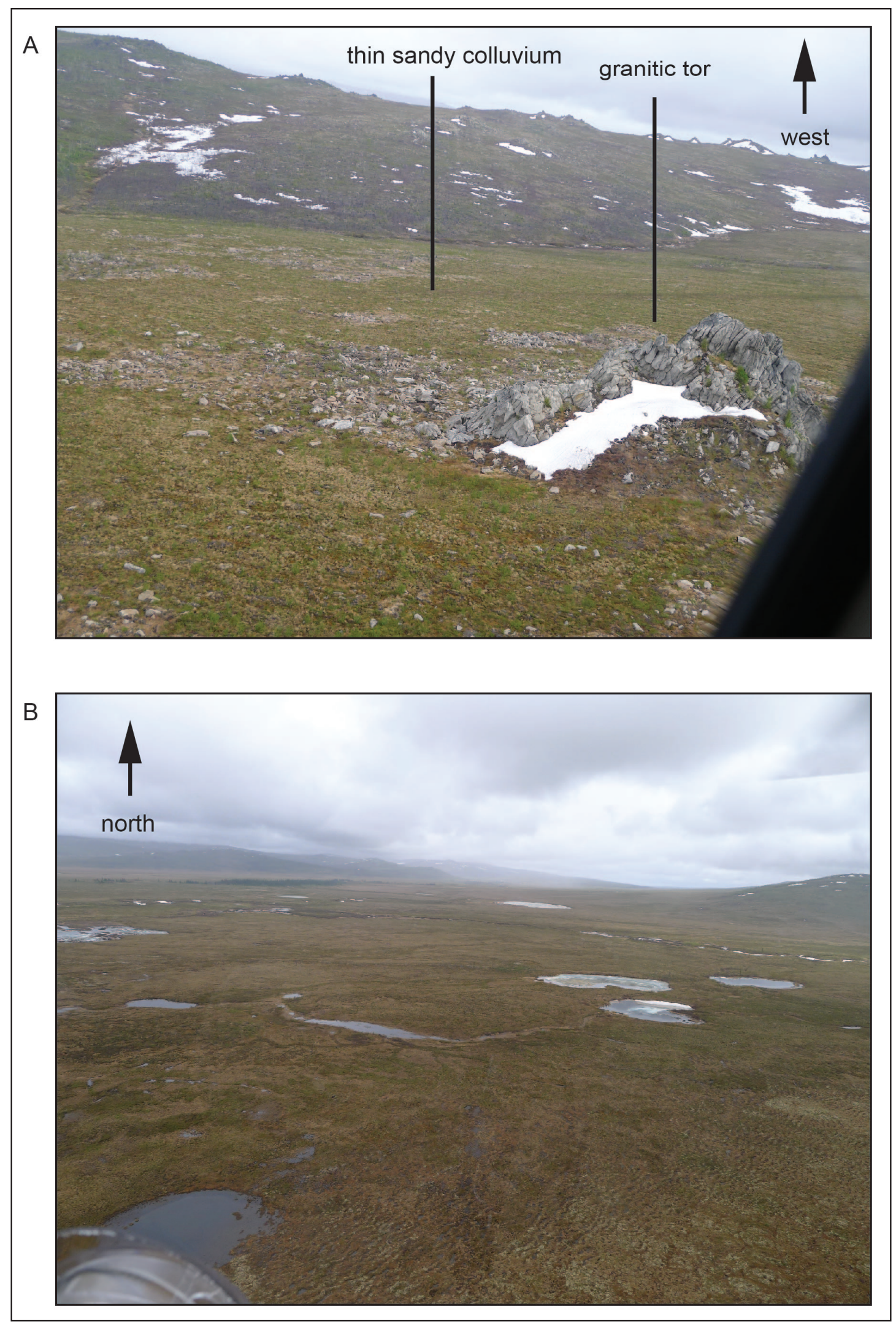

Figure 20. A. Photograph showing residual outcrops, which are common along bedrock slopes mantled by sandy colluvium directly south of Olsons Lake basin. B. View of Olsons Lake basin, which is characterized by thaw lakes and polygonal ground. 


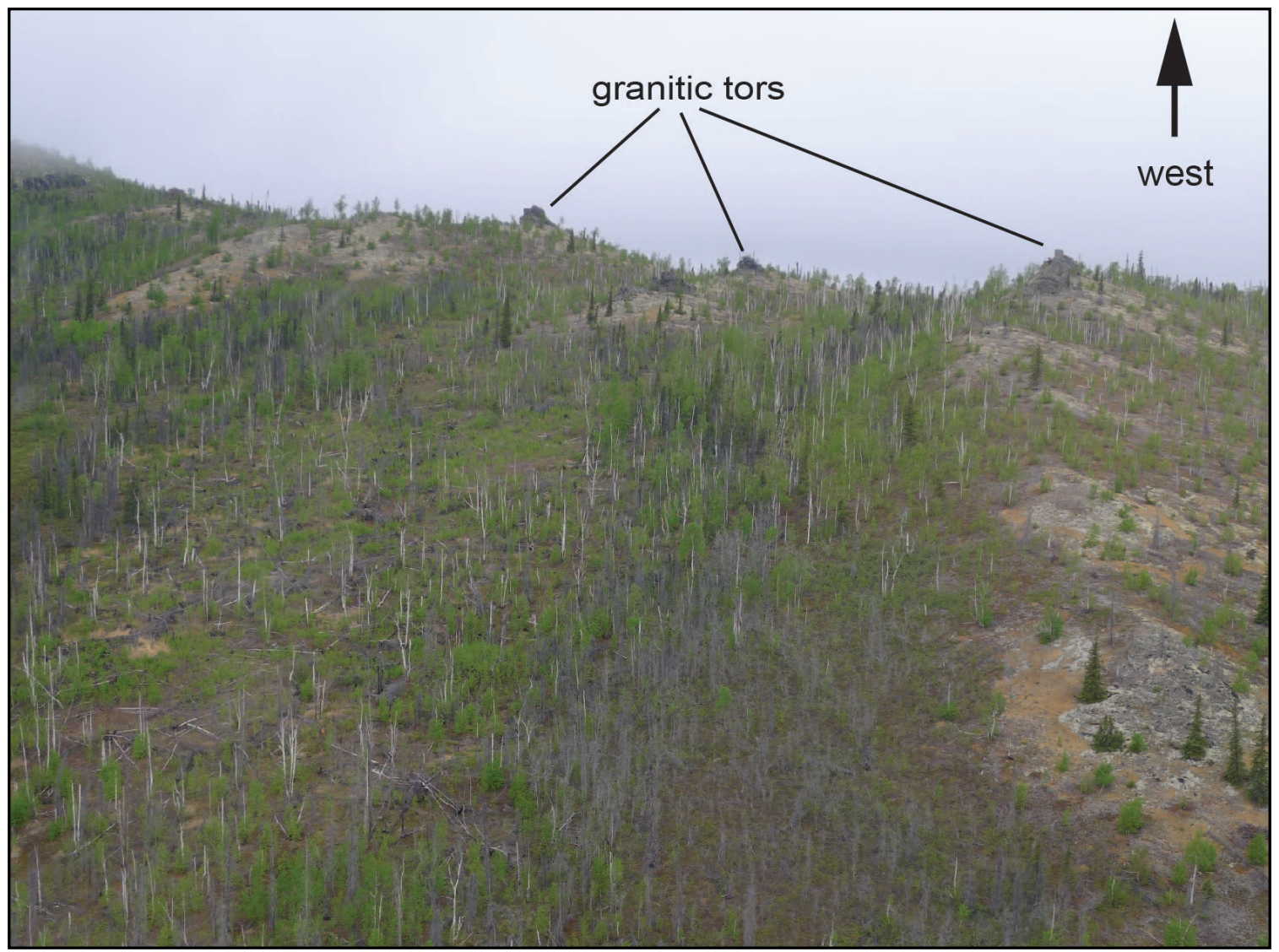

Figure 21. View toward west, showing prominent tors on ridge crests north of the Kanuti River. Lower slopes are characterized by sandy, colluvial grus aprons.

has produced bedrock eminences (tors) where bedrock joints are widely spaced in the upland and sandy grus-filled swales and gullies where bedrock joints are closely spaced. Surface grus is $2-4 \mathrm{ft}(0.6-$ $1.2 \mathrm{~m})$ thick over more than 8-35 ft $(2.4-10.7 \mathrm{~m})$ of weathered granitic bedrock (Kreig and Reger, 1982, pl. 18). Next, the corridor extends for 1.6 mi across a strip of Paleozoic phyllite and metagraywacke and late Paleozoic to middle Mesozoic mafic volcanic rocks (Patton and Miller, 1973). For the next $0.5 \mathrm{mi}$ to Prospect Creek, Quaternary sediments include silty colluvium overlying fine-grained ice-marginal lake sediments and till of the Anaktuvuk River glaciation of early Pleistocene age. This locality represents the southernmost known limit of glaciation from the southern Brooks Range and local sources in the corridor (Hamilton, 1994), and was identified in subsur- face stratigraphy encountered in borings. Along the corridor, drift of the Anaktuvuk River glaciation forms a discontinuous formless blanket over ice-scoured bedrock outside the maximum limit of the Sagavanirktok River glaciation of middle Pleistocene age.

North of Prospect Creek, the corridor crosses $5.5 \mathrm{mi}$ of shallowly buried late Paleozoic to middle Mesozoic mafic volcanic rocks to the southeastern edge of the Jim River lowland. The lowland is underlain by fluvial terraces of middle Pleistocene age (Hamilton, 2002) and the modern floodplain of the Jim River (fig. 22). Sloping fine-grained aprons on lower bedrock slopes and along the margins of the terraces are composed of solifluction colluvium and reworked ancient till and glaciofluvial deposits. Terrace treads continue along the southeastern side of the corridor to the crossing of Jim River. 


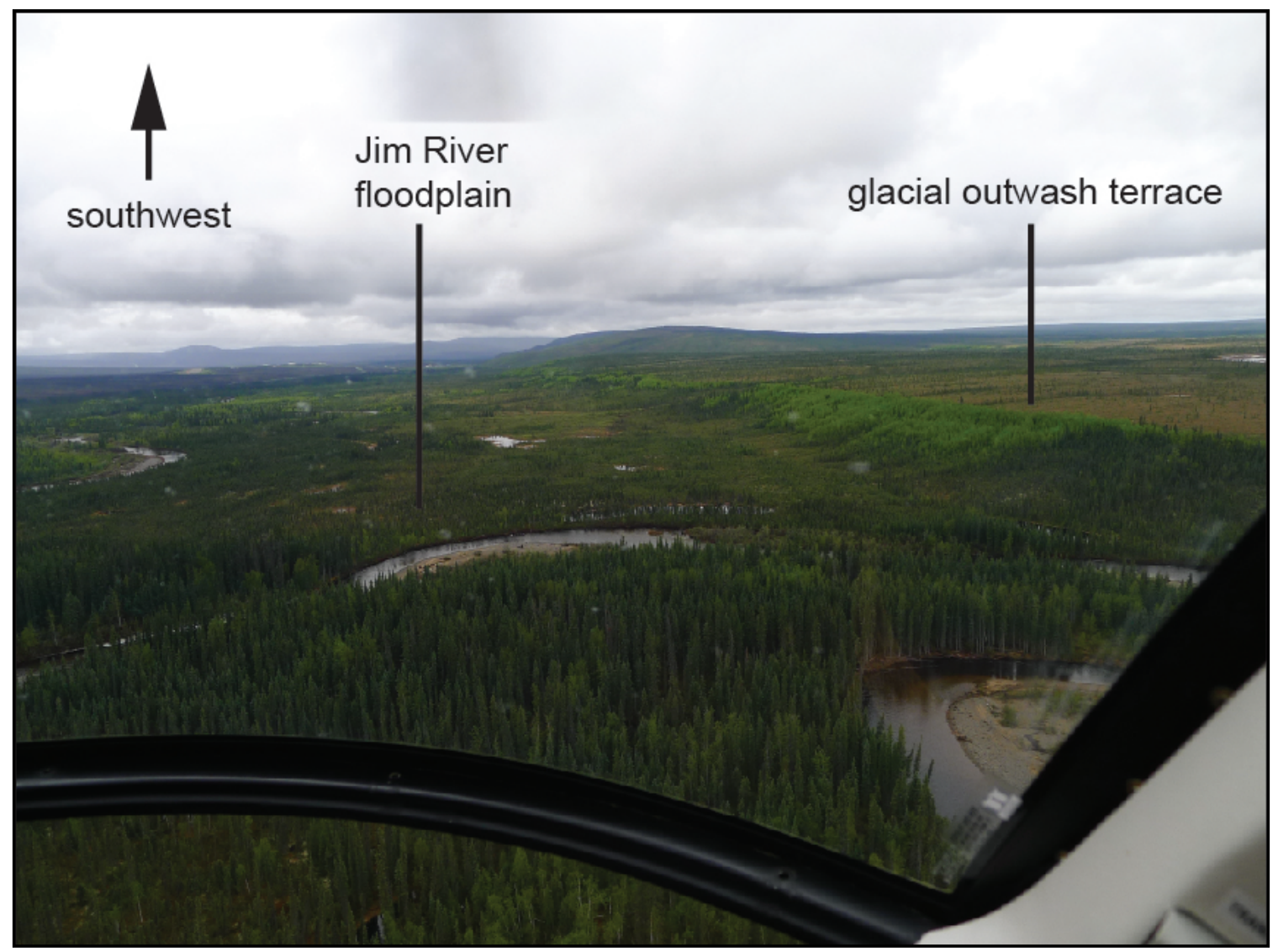

Figure 22. View toward southwest of the Jim River floodplain near Douglas Creek. The river tightly meanders through fluvial terraces and is bordered on the northeast by a prominent glacial outwash terrace.

Jim River to South Fork Koyukuk River

\section{BETTLES D-1 QUADRANGLE, 1:63,360 SCALE}

The corridor extends $-8.5 \mathrm{mi}$ northeast from the crossings of Jim River to the South Fork Koyukuk River through a fairly straight, 1,300-ftdeep (-400-m-deep), U-shaped bedrock trough that contains Grayling Lake. The trough was intensely scoured by ice from the southern Brooks Range during the Sagavanirktok River glaciation of middle Pleistocene age (table 1). That glacier terminated in the upper Jim River drainage -2.0 mi downvalley from the crossing of Jim River.

The Grayling Lake corridor appears much older than valley walls scoured by the younger Itkillik glaciation in the Middle Fork Koyukuk River to the north in the southern Wiseman Quadrangle. The steep bedrock walls of the Gray- ling Lake corridor are thinly covered by solifluction-modified glacial and glaciofluvial deposits of the Sagavanirktok River glaciation; ice-scoured, weathered bedrock knobs more commonly stand out from the northwestern valley wall than the smoother southeastern valley wall. Colluvial fans, built by slope processes, on opposite valley walls have different appearances. On the lower northwestern valley wall, colluvial fans built by debris flows and solifluction onto deposits of the Sagavanirktok River glaciation at the mouths of short, steep tributary gullies are smaller, thinner, and smoother than massive colluvial fans deposited on the southeastern valley wall (fig. 23A). Fans there are dominantly composed of coarse rock rubble that was initially deposited on glacial deposits as mixed fine and coarse sediments by slush flows, debris flows, and snow avalanches (fig. 23B). The colluvial fans are associated with colluvial 


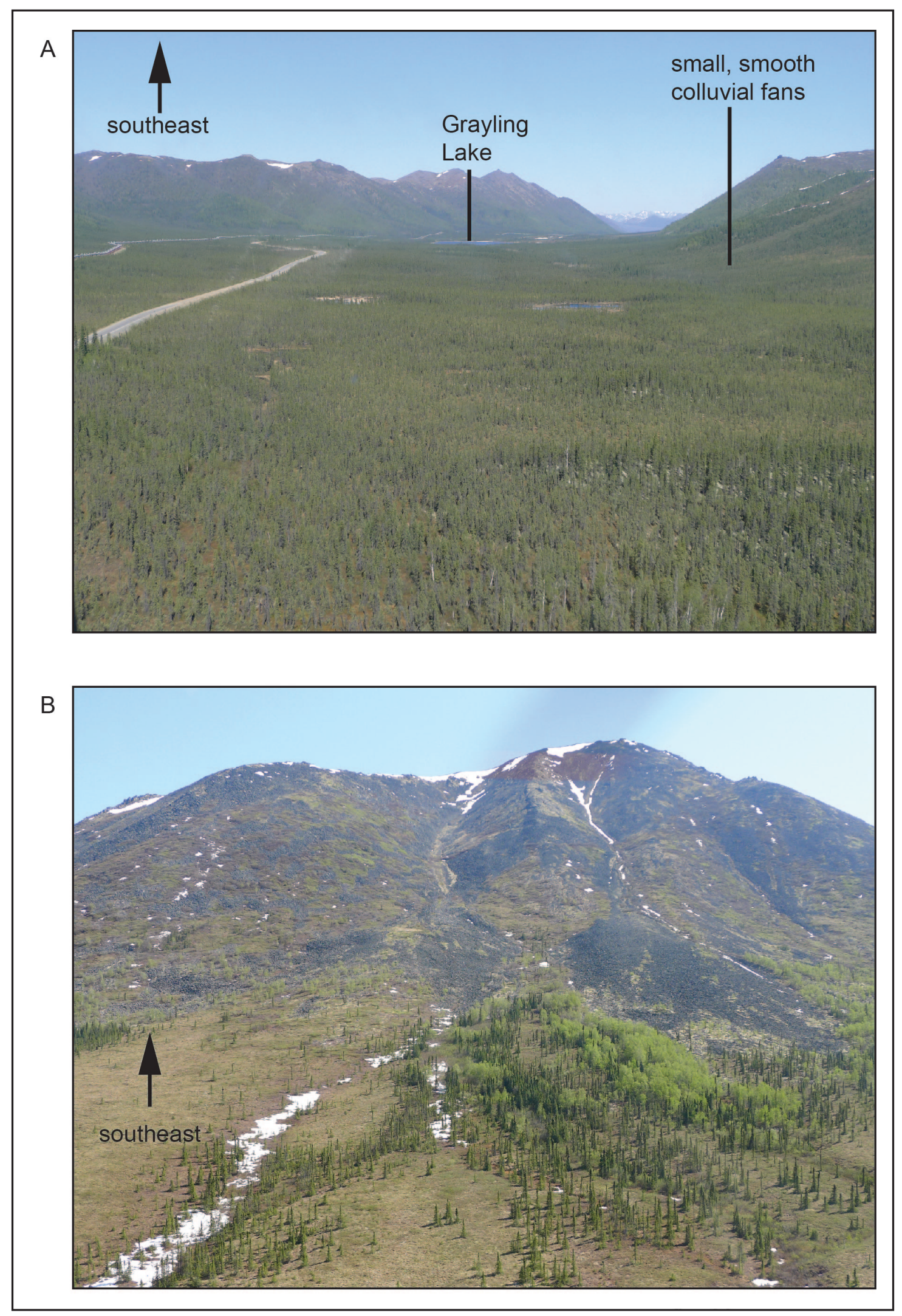

Figure 23. A. Southeast view of the corridor in the area of Grayling Lake, showing small, smooth colluvial fans along the northwestern valley wall. B. Coarse rock rubble fans along the southeastern valley wall of the corridor in the Grayling Lake area. 
aprons that were also initially composed of fine and coarse solifluction deposits. Subsequently, the fine fractions of the colluvial fans and aprons were removed by subsurface piping, leaving the very coarse rubble fans and rubble sheets as lag on the southeastern valley wall.

\section{South Fork Koyukuk River to Middle Fork Koyukuk River (boundary of Wiseman and Chandalar quadrangles)}

WISEMAN A-1 AND B-1 QUADRANGLES, $1: 63,360$ SCALE

From the South Fork Koyukuk River, the corridor gradually ascends -3.0 mi northwestward through a short, narrow, glaciated corridor through the rounded hills of the eastern Jack White Range and crosses a narrow, sharp, northeast-trending linear ridge (fig. 24) that represents the maximum southward extent of the last major (Itkillik) glacia- tion from the southern Brooks Range (Hamilton, 1979). Southward from the terminal moraine, a short ribbon of Itkillik outwash extends through the eastern Jack White Range to the South Fork Koyukuk River and spreads down the Koyukuk River toward the southwest.

North of the small Itkillik terminal moraine, the corridor extends northward $-7 \mathrm{mi}$ across frozen glacial and ice-stagnation deposits of the Itkillik glaciation to the margin of the active braided floodplain of the Middle Fork Koyukuk River (Hamilton, 1979). The topographic trough between the eastern Jack White Range (west of the map area) and Twelvemile and Cathedral mountains at the mouth of the Middle Fork Koyukuk River valley was almost completely filled with ice during the last major (Itkillik) glaciation (Hamilton, 1979, 2002). In this segment, the presence of thermokarst-modified kettle lakes with steep, active margins reflects the presence of thick,

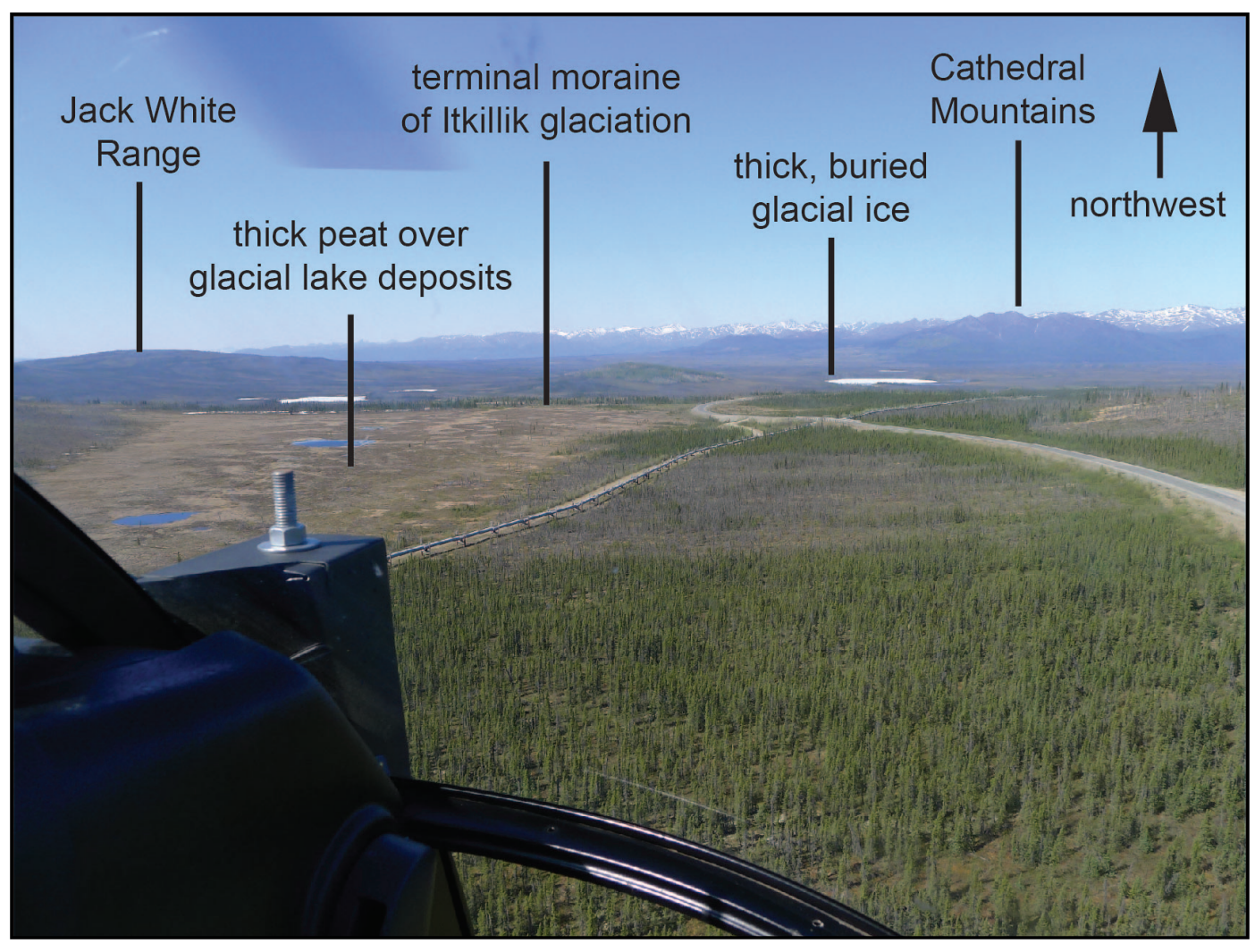

Figure 24. View toward northwest of terminal moraine of Itkillik glaciation north of the South Fork Koyukuk River. Thick, buried glacial ice is present in the topographic trough between the eastern Jack White Range and the Cathedral Mountains, resulting in the thermokarst modification of kettle lakes. 
massive, buried glacial ice preserved for $-10,000$ years since the end of the Itkillik glaciation in the perennially frozen glacial deposits (fig. 24). Local sources of granular aggregate are present in the icestagnation deposits through this section.

The Malamute fault extends across the corridor about $1 \mathrm{mi}$ south of the southern flanks of Cathedral Mountain and Twelvemile Mountain. This Devonian-Cretaceous, right-lateral fault bounds the north side of the Koyukuk Basin (Mull and Adams, 1989), but is not expressed in Quaternary deposits, suggesting that it is likely not active. Three additional faults cross the corridor north of Cathedral Mountain including the south, middle, and north strands of the Angayucham fault (Mull and Adams, 1989). These Mesozoic thrust faults also do not displace Quaternary deposits in the Middle Koyukuk River valley in the corridor.

From the southern flank of Cathedral Mountain, the corridor extends for $3.6 \mathrm{mi}$ to the mouth of Rosie Creek and follows the floodplain of the Middle Fork Koyukuk River (fig. 25). Bedrock of Cathedral Mountain hosts high levels of naturally occurring asbestos (Solie and Athey, 2015). In this section, the floodplain is braided and covered by thick stream icings each winter. According to Hamilton (1979), fine-grained lacustrine sediments are present beneath the granular floodplain sediments. We suggest that those fine-grained sediments provide a near-surface impermeable barrier to the downward movement of shallow groundwater, promoting the formation of the surface icing sheets. Rapid mass movements derived from the adjacent slopes during extreme weather events represent a persistent hazard in this area.

North of Rosie Creek, the eastern side of the corridor climbs and follows the crest of a low end moraine of an early Itkillik glacial readvance 4.8 mi northeastward before descending onto the alluvial fan of Slate Creek, near Coldfoot. North of the

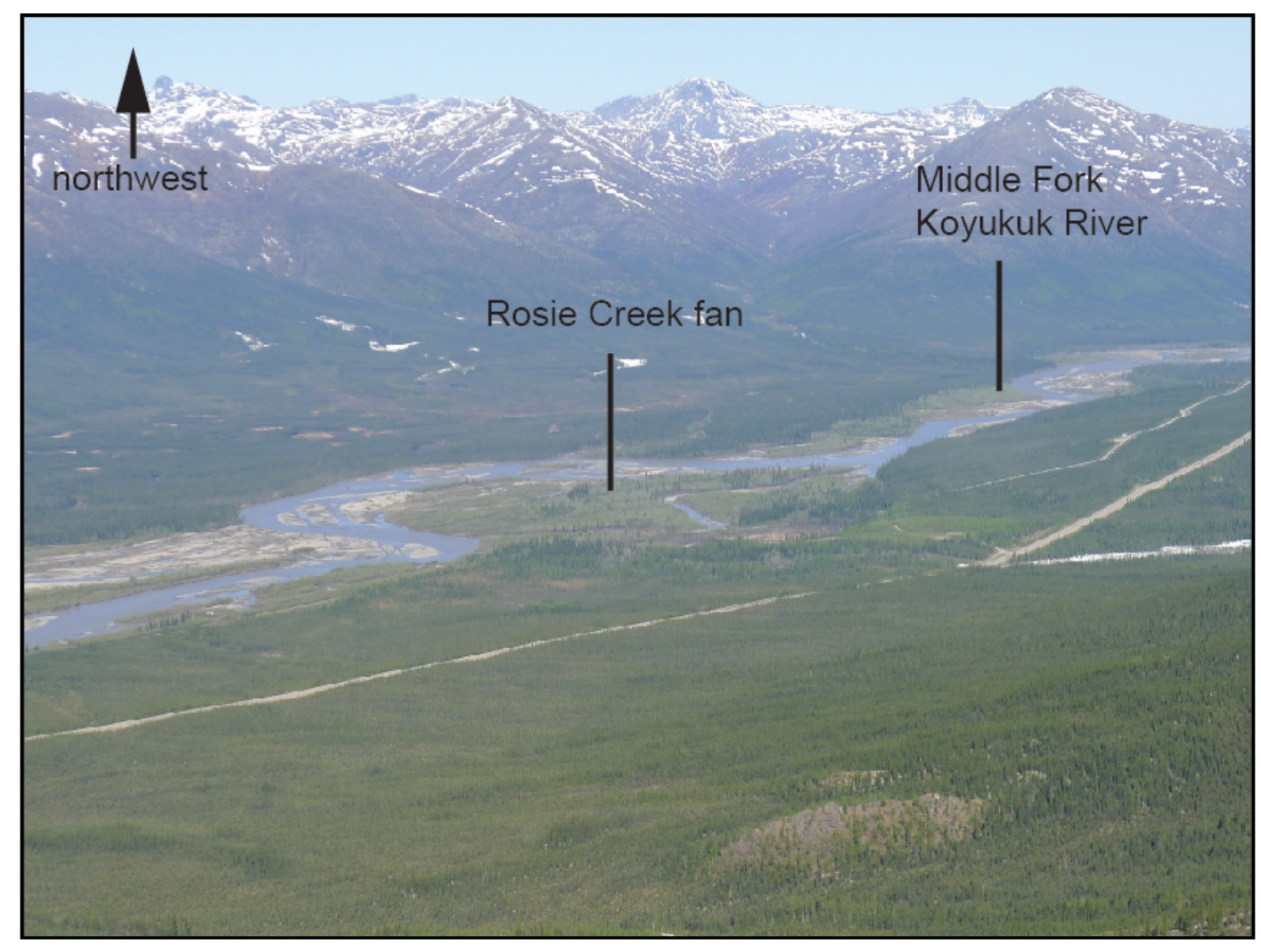

Figure 25. View, looking northwest from Cathedral Mountain, of the Middle Fork Koyukuk River and the Rosie Creek alluvial fan. 
Slate Creek fan, a short $(0.5 \mathrm{mi})$ segment of Itkillik glacial drift is traversed to the southern edge of the Clara Creek alluvial fan. From the Clara Creek fan northward for about $10 \mathrm{mi}$ to Minnie Creek, the corridor continues along the Middle Fork Koyukuk River. Fluvial terraces fringe the active floodplain and coarse grained alluvial fans flank the western side of the corridor. Deposits along the eastern side of the active floodplain consist of Itkillik glacial drift and fluvial terraces to an abrupt erosional scarp about $1.5 \mathrm{mi}$ south of Dry Creek, which marks the beginning of a late Itkillik-age outwash surface that extends to the north. This outwash surface extends for $-3.3 \mathrm{mi}$ to a low end moraine that delineates the downvalley limit of a late Itkillik readvance of the Middle Fork glacier (Hamilton, 1979). The belt of low morainal ridges is crossed northward for $-1.5 \mathrm{mi}$ before intersecting the alluvial fan of Minnie Creek. A short segment of the latest Itkillik moraine is preserved north of Minnie Creek. Where this deposit has been incised by the Middle Fork Koyukuk River, exceptionally thick river icings develop each winter and fine-grained late Itkillik lake sediments are present at depth (Hamilton, 1979). Between Minnie Creek and the eastern boundary of the Wiseman B-1 Quadrangle numerous thaw failures and frozen debris-flow deposits are present along the northwestern side of the floodplain (site 225, sheet 3, map 9, Lat./Long. 67.4662, -150.0790), and low bedrock slopes along the southeastern side are mantled with till.

\section{Middle Fork Koyukuk River to Dietrich River and Table Mountain} CHANDALAR B-6, C-6, AND D-6 QUADRANGLES, $1: 63,360$ SCALE

From the western boundary of the Chandalar B-6 Quadrangle in the glaciated valley of the Middle Fork Koyukuk River, the corridor traverses $-15 \mathrm{mi}$ to the downstream end of the Dietrich River. Steep debris-flow fans and massive, creeping colluvial lobes are present along the steep slopes on the northwest side of the corridor. These lobes have been referred to as frozen debris lobes in recent literature (Simpson and others, 2016; Hubbard and others, 2013; Spangler and Hubbard, in press; Spangler and others, 2013; Darrow and others, 2012 ; 2013; 2016). Along the eastern side of the valley, the first $-3.4 \mathrm{mi}$ of this section extends across late Itkillik outwash and low Holocene river terraces and crosses the narrow floodplains of several small streams to the alluvial fan of Nugget Creek (fig. 26). For the next $1.4 \mathrm{mi}$ the corridor crosses till of late Itkillik age to the small alluvial fan of Gold Creek. North of Gold Creek the corridor extends $\rightarrow 9 \mathrm{mi}$ northward across glacier-scoured bedrock that is thinly buried by till to the edge of the active braided floodplain at the junction of the Middle Fork Koyukuk, Bettles, and Dietrich rivers (fig. 27). Each winter, thick stream icings develop on the floodplains, indicating that shallow subsurface water is under elevated hydraulic pressure. According to Hamilton (1978a) lacustrine sediments of late Itkillik age underlie the floodplains in this segment. These subsurface lake sediments underlie the downstream $10.0 \mathrm{mi}$ of the braided Dietrich River floodplain.

In the lower $6 \mathrm{mi}$ of the intensely glaciated lower Dietrich River valley, the corridor extends through till of the late Itkillik glaciation and glacially scoured bedrock discontinuously covered by thin till to Snowden Creek. Along this section the corridor crosses several alluvial fans of eastern tributaries to the Dietrich River. The next $2.0 \mathrm{mi}$ segment northward traverses ice-scoured bedrock with a thin surface blanket of till to the 0.5 -milong crossing of adjoining colluvial-alluvial fans from two steep, unnamed tributaries on the southwestern flank of Snowden Mountain. Large alluvial fans have built out into the Dietrich River floodplain in this area.

A distance of $2.7 \mathrm{mi}$ north of the colluvialalluvial fans, in the vicinity of Dalton Highway MP 219, the terminus of an actively advancing tongue of frozen debris from an unnamed eastern tributary valley presents a potential hazard to the highway and potential future developments 


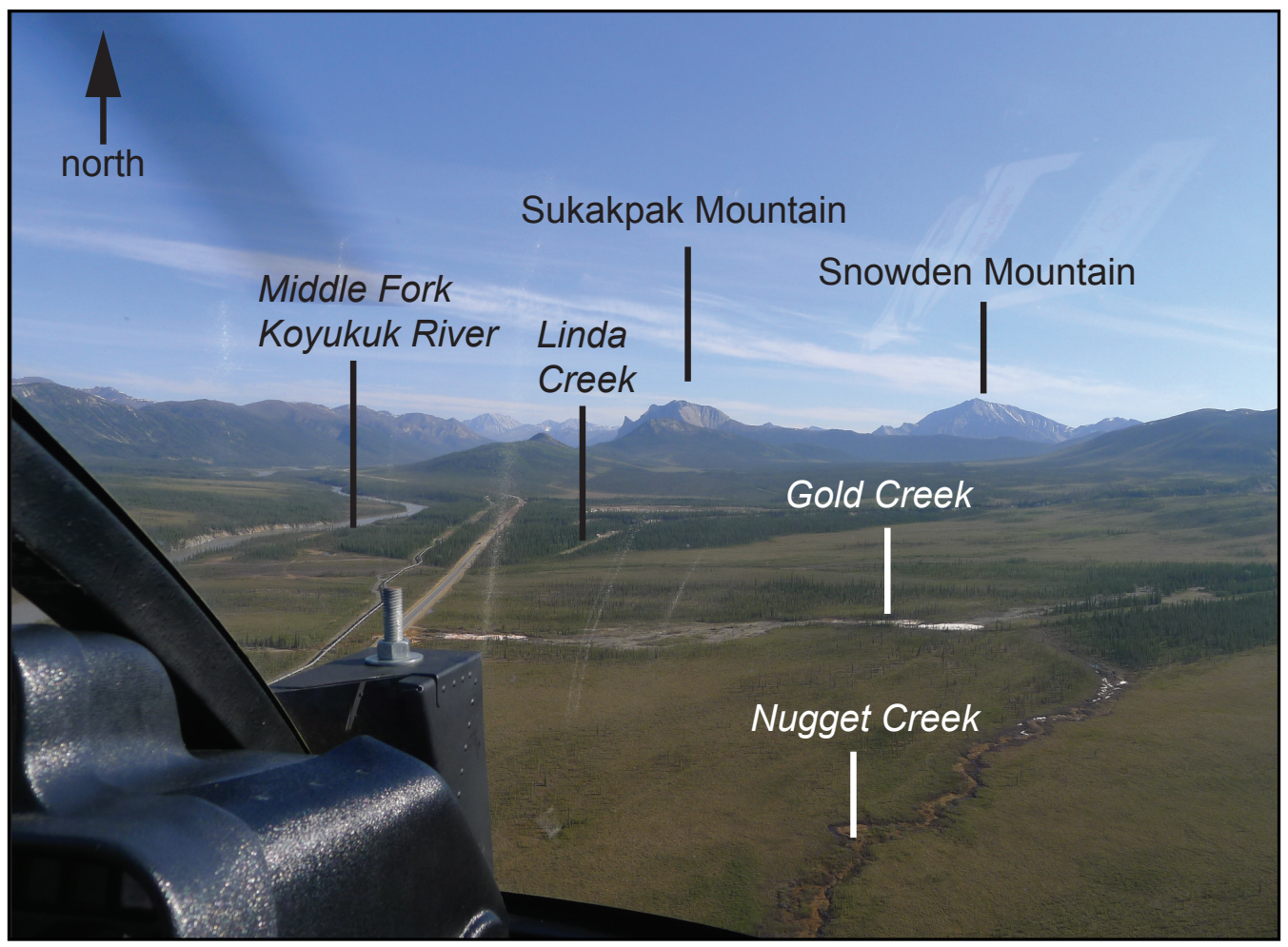

Figure 26. Aerial view toward the north, showing alluvial fans along tributaries to Middle Fork Koyukuk River including Nugget, Gold, and Linda creeks.

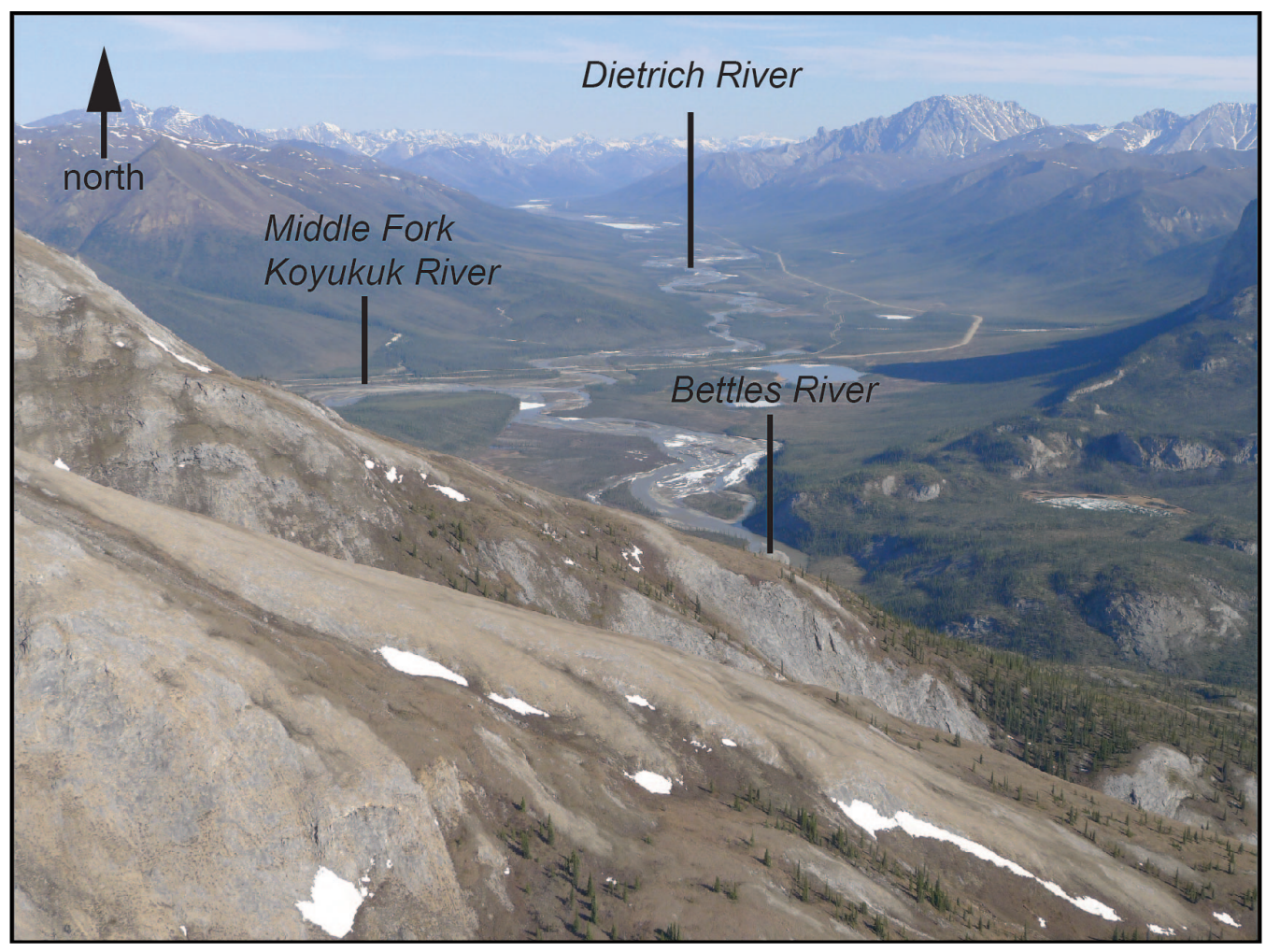

Figure 27. View to the north from Sukakpak Mountain toward the junction of the Middle Fork Koyukuk, Bettles, and Dietrich rivers. 
(fig. 28)(site 229 at north edge of sheet 3, map 9, Lat./Long. 67.8119, -149.8136). At that location in 2012, the terminus of the most advanced debris tongue had approached to within $-200 \mathrm{ft}(61 \mathrm{~m})$ east of the eastern shoulder of the northbound lane (Darrow and others, 2012). This 5,700-ftlong (1,737-m-long) debris tongue is $-790 \mathrm{ft}$ $(241 \mathrm{~m})$ wide and as thick as $-100 \mathrm{ft}(30.5 \mathrm{~m})$ near the terminus. Comparison of aerial imagery taken $7 / 22 / 55,7 / 1 / 79$, and 8/24/08 demonstrates that rates of frontal advance were 6.9 and 11.2 $\mathrm{ft} / \mathrm{yr}(2.1$ and $3.4 \mathrm{~m} / \mathrm{yr})$, for an average rate of $-0.39 \mathrm{in} /$ day $(9.9 \mathrm{~mm} /$ day) (Daanen and others, 2012). Ground-based measurements in 2009 and 2010 demonstrate that the annual rate of terminal advance was $-11.8 \mathrm{ft} / \mathrm{yr}(3.6 \mathrm{~m} / \mathrm{yr})$, equivalent to slightly more than $-0.4 \mathrm{in} /$ day $(-10.2 \mathrm{~mm} /$ day $)$. Several other debris features have been identified in the valley of the Dietrich River using 2010 lidar-derived hillshade models. Many of these debris features develop where accelerated frost weathering of mica and quartz-mica schists, phyllite, fine sandstone, and platy limestones exposed in steep topographic basins at the heads of short side valleys supply voluminous fine-grained sediments that move as blankets down headwall slopes as debris flows during brief torrential downpours and by frost creep, flow, and basal sliding (solifluction) (Spangler and Hubbard, in press). The moving rock debris initially accumulates on the lower headwalls and becomes perennially frozen. Once an adequate volume of debris accumulates, it deforms downvalley under the influence of gravity. Steep walls in narrow side valleys confine the slowly advancing mass to form debris tongues. The same processes produce stubby, sloping debris benches and spatulate lobes with steep marginal scarps along unconfined lower sidewalls in the main river valley.

From the MP 219 debris tongue the corridor continues northward for $8.4 \mathrm{mi}$ along the Dietrich River to Nutirwik Creek, just south of Table Mountain. This section exhibits similar characteristics to the lower Dietrich River valley, extending across glacial drift of late Itkillik age, ice-scoured bedrock thinly blanketed with till, floodplain and terrace deposits of the Dietrich River, and several large alluvial fans (fig. 29). Several faults in bedrock project across the corridor along this stretch. These faults have caused isoclinal folding and repeated sections of the local bedrock units, indicating that they are dominantly thrust faults (Mull and Adams, 1989). The faults do not offset Quaternary units in the corridor and are likely not active.

From Nutirwik Creek the corridor follows the narrow floodplain of the upper Dietrich River for $3.4 \mathrm{mi}$ to the northern boundary of the Chandalar Quadrangle. Colluvial-alluvial fans built out from short, steep canyons are the dominant landforms along the Dietrich River. Directly north of Nutirwik Creek a zone of deep-seated failures in bedrock is present along the western margin of the upper Dietrich River (See numerous features labeled 'Cl' on the Chandalar D-6 quadrangle, sheet 4, map 10). These massive, complex landslides are identified by very steep bedrock scarps that stand several tens of meters above the heads of the large bedrock failures. Below the scarps, the bodies of the slides are covered with discontinuous, locally disturbed spruce forest associated with alder and willow shrubs. Slide bodies are locally humped and fissured, and some large failures grade downslope into debris-flow slides. Their vegetation and humped and fissured character could be evidence that the landsides are advancing, but at fairly slow rates.

\section{Uppermost Dietrich River and Table Mountain to Atigun River Gorge} PHILIP SMITH MOUNTAINS A-4, A-5, B-4, AND B-5 QUADRANGLES, 1:63,360 SCALE

From the southern margin of the Philip Smith Mountains A-4 Quadrangle the corridor continues to follow the upper Dietrich River valley for $2.5 \mathrm{mi}$, crossing floodplain deposits, numerous alluvial fans, and glacially scoured bedrock slopes. Another zone of deep-seated, complex landslides in bedrock extends along the west side of the upper 


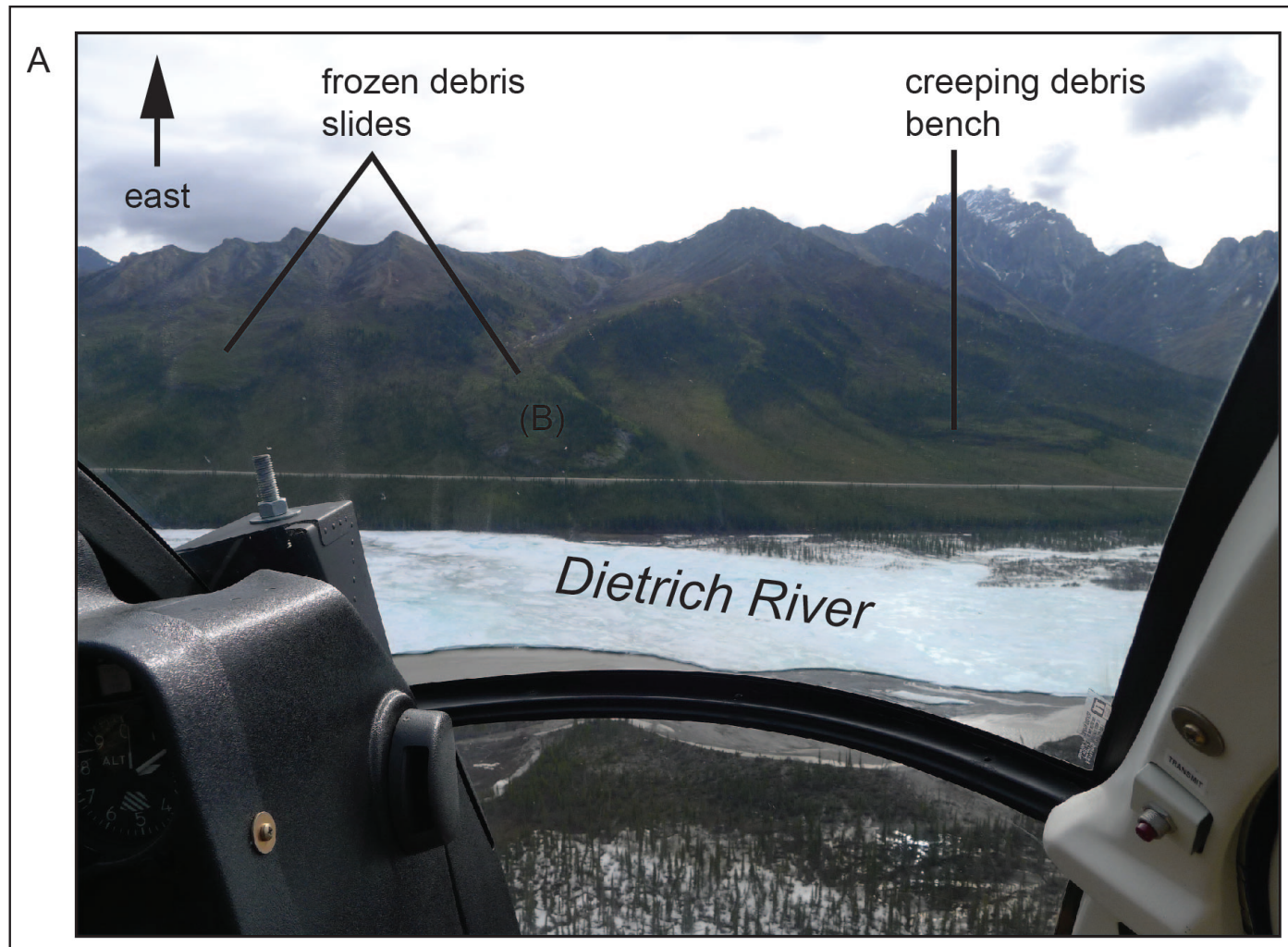

B

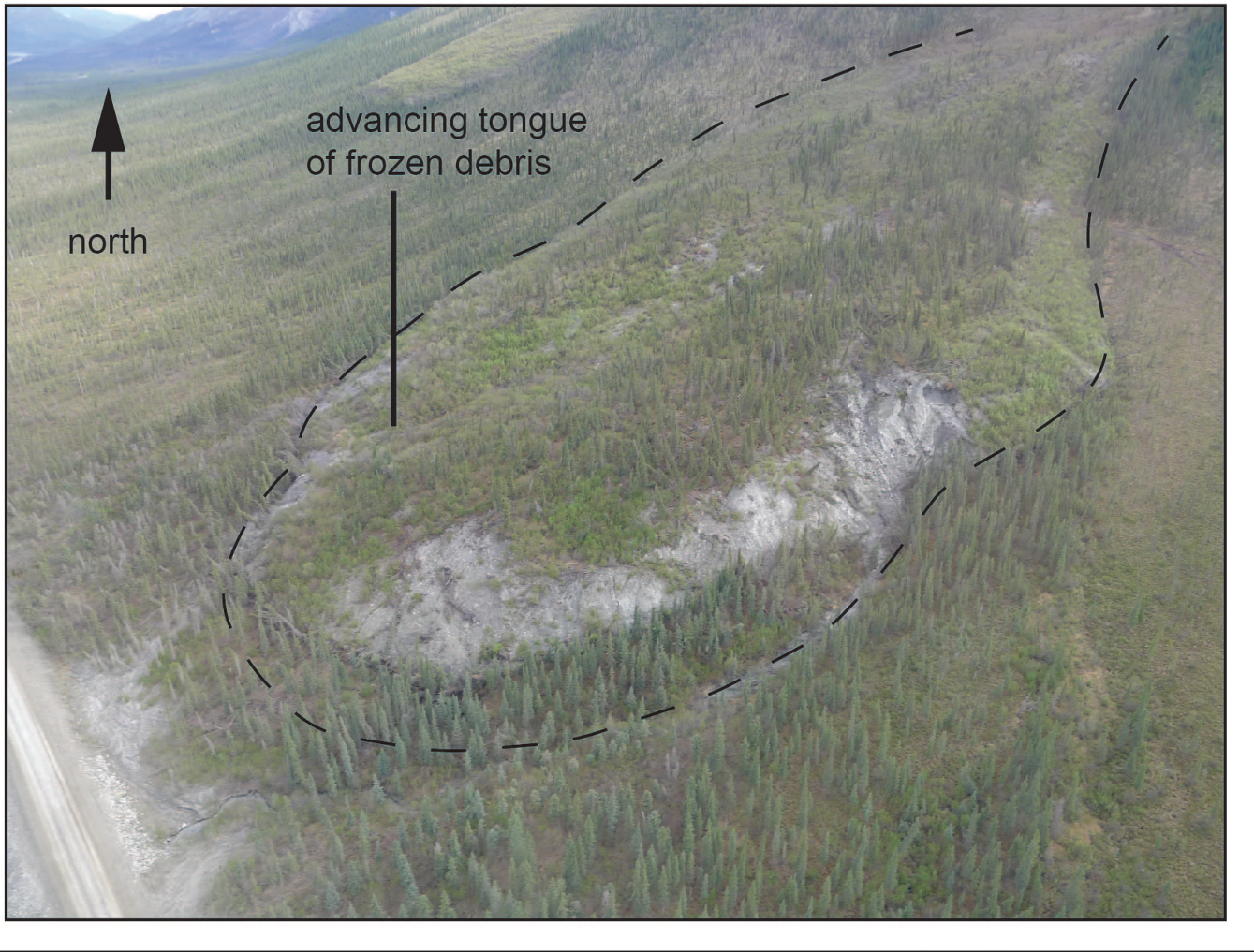

Figure 28. A. View, toward the east, of massive creeping, frozen colluvial lobes along both sides of the Dietrich River valley. These lobes typically have bench or tongue morphology. B. View, facing north, of actively advancing tongue of frozen debris near MP 219 of the Dalton Highway, approximately $131 \mathrm{ft}(40 \mathrm{~m})$ from the highway. Feature is outlined by dashed black line. 


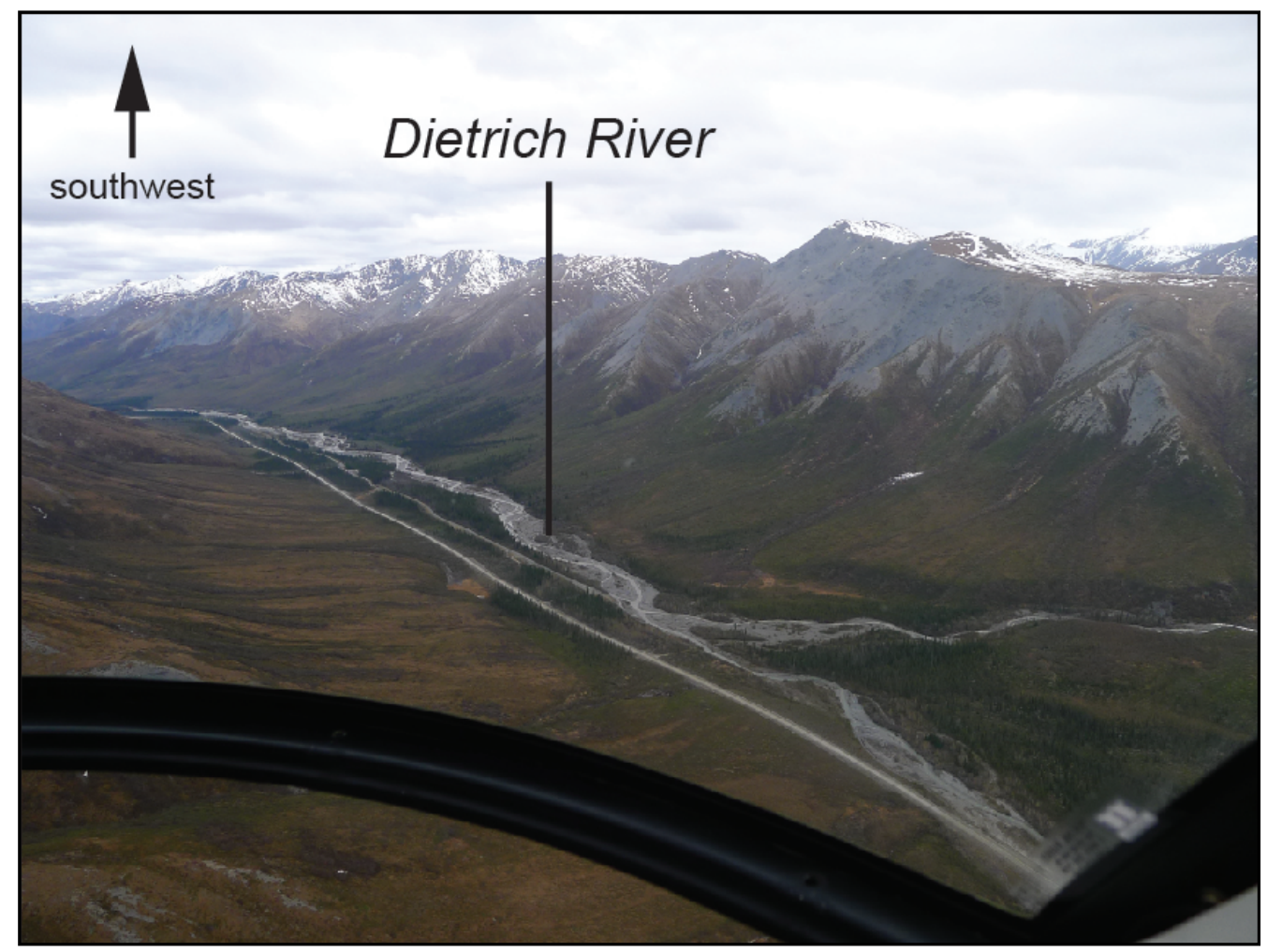

Figure 29. View toward the southwest of alluvial fans, floodplain terraces, and thin till along the valley margins of the Dietrich River south of Nutirwik Creek.

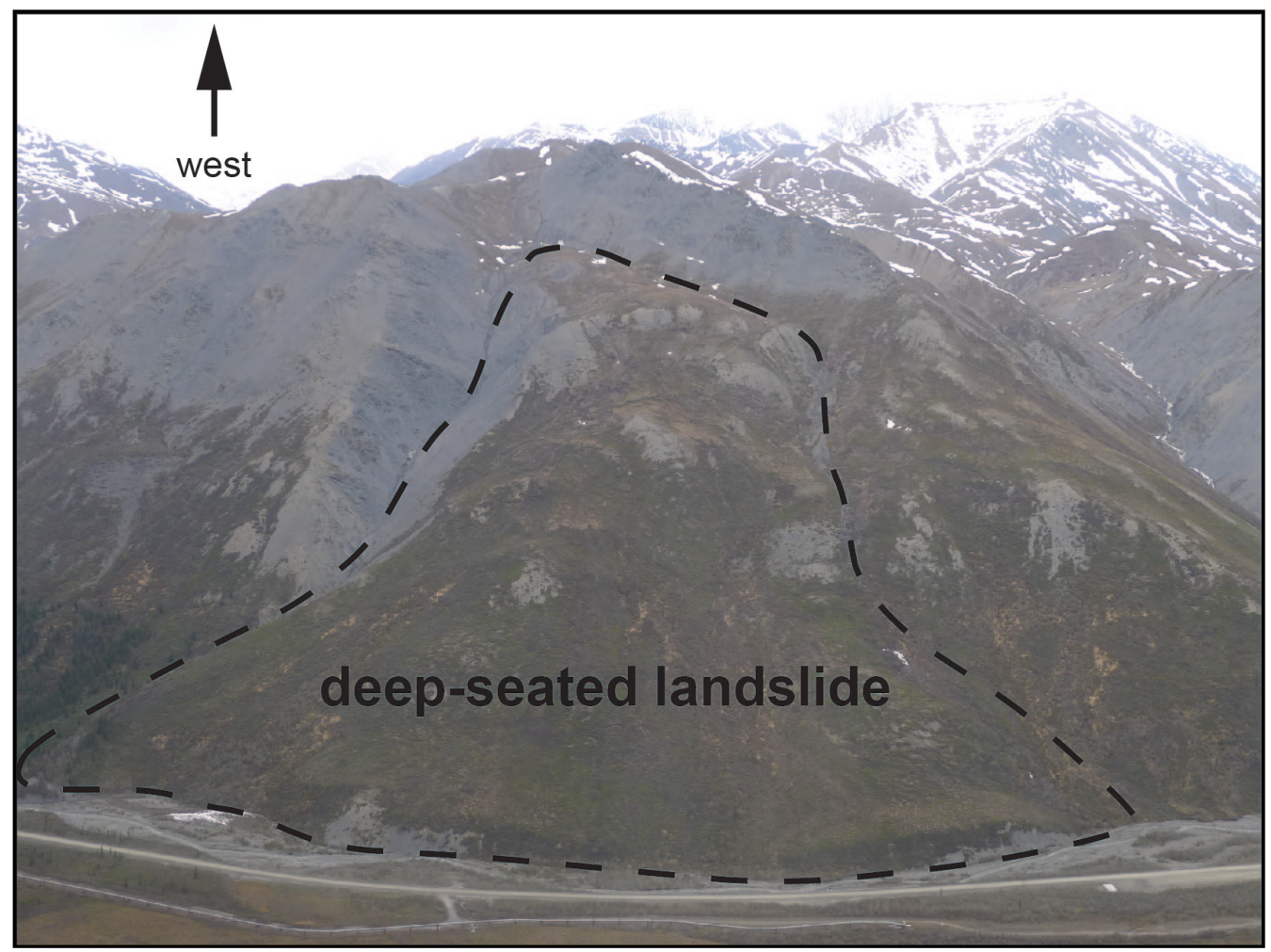

Figure 30. View toward the west of massive, deep-seated landslides in bedrock north of Nutirwik Creek along the western margin of the upper Dietrich River. Margins of slide are indicated by dashed black line. 
Dietrich River for $1.5 \mathrm{mi}$ to the base of the steep slope below the Chandalar Shelf (fig. 30) (site 232, sheet 4, map 10, Lat./Long. 68.0359, -149.6993). The corridor then climbs $-0.7 \mathrm{mi}$ to the level of the Chandalar Shelf.

The Chandalar Shelf is the southern edge of a northeast-trending straight valley with a $U$-shaped cross profile that is typical of intensely glaciated mountain valleys (Hamilton, 1978b). The valley extends to the continental divide at Atigun Pass (fig 31A). The first $1.7 \mathrm{mi}$ of the corridor on the shelf crosses thin Itkillik glacial deposits blanketing ice-scoured bedrock to a 0.4 -mi-long linear fluvial scarp cut by an unnamed tributary of the North Fork Chandalar River across the toe of a colluvial fan built by slush flows that are still active at this locality (Chandalar Camp) (fig. 31B).

In the higher mountains near the crest of the Brooks Range, the slush-flow season occurs in May, when sudden air-temperature increases typically cause rapid production of meltwater, which leads to saturation of the seasonal snowpack and release of slurries of snow, ice, and water (slush flows) on slopes as shallow as 1 degree. These slurries sweep snow, ice, and colluvium from the floors of higher alpine drainages, heralding the annual breakup season. In steep alpine gullies slush flows generate momentums and velocities sufficient to cause super-elevation on the outside bends in narrow chutes. Large volumes of flowing, debrisladen slush and high momentums result in severe impacts with objects in slush-flow chutes and on slush-flow fans. These colluvial fans characteristically have rounded humps of angular rock debris up to the size of $4.9 \mathrm{ft}(1.5 \mathrm{~m})$ boulders on upper fan surfaces and are littered with scattered boulders. Recently active chutes are identified by vertical transverse scarps across the lower ends of undisturbed snow fills (marking the upvalley limit of the slush flow), sediment-rich masses of snow and ice on chute floors and walls, and chunks of ice and fresh rock debris scattered across the fan. Several slush-flow fans are active on the Chandalar Shelf and in the upper Atigun River valley north of Atigun Pass, and slush flows affect fans historically used for support facilities, storage sites, and aggregate sources in the Atigun Pass area.

From the Chandalar Camp fan the corridor extends $-2.7 \mathrm{mi}$ to the northern end of the valley where the Dalton Highway and the buried TAPS pipeline begin their ascent to Atigun Pass $(4,739$ $\mathrm{ft}[1,444 \mathrm{~m}]$ elevation) at the crest of the central Brooks Range. In this section nearly continuous coalescing slush-flow fans bury thin glacial deposits and extend from both sides of the valley to the axial river. We observed a slush-flow deposit that released in spring 2013 at the mouth of a southwest-trending valley at the north end of the valley (fig. 32, Lat./Long. 68.1115, -149.5205). This slush flow deposited large blocks of ice and boulders and extended to the margin of the composite slush-flow fan. About $0.9 \mathrm{mi}$ up the Atigun Pass canyon, a particularly hazardous slush-flow chute crossing the Dalton Highway from the northwest has a history of activity resulting in damage to the guardrail and to road-maintenance equipment that happened to be crossing the chute when a slush flow released.

From the slush-flow chute for about $2 \mathrm{mi}$ the corridor extends across rugged mountain topography to the summit at the continental divide (Atigun Pass). The Dalton Highway skirts ice-rich, creeping, coarse colluvium on the lower valley wall, where high maintenance expenses are associated with rock debris on the highway. A 1.5-mi-wide snow-avalanche zone is centered on Atigun Pass. North of the pass, the corridor crosses $0.8 \mathrm{mi}$ of thin Holocene glacial drift and bedrock and descends onto the floor of the upper Atigun River valley. About $0.3 \mathrm{mi}$ north of the foot of the downgrade, the corridor crosses the toe of a large, active slush-flow fan for $0.2 \mathrm{mi}$.

The next $2.1 \mathrm{mi}$ of the corridor northward traverses through rugged mountains and the upper Atigun River valley to the junction of two branches of the upper Atigun River valley at former Atigun Camp (along the boundary of 


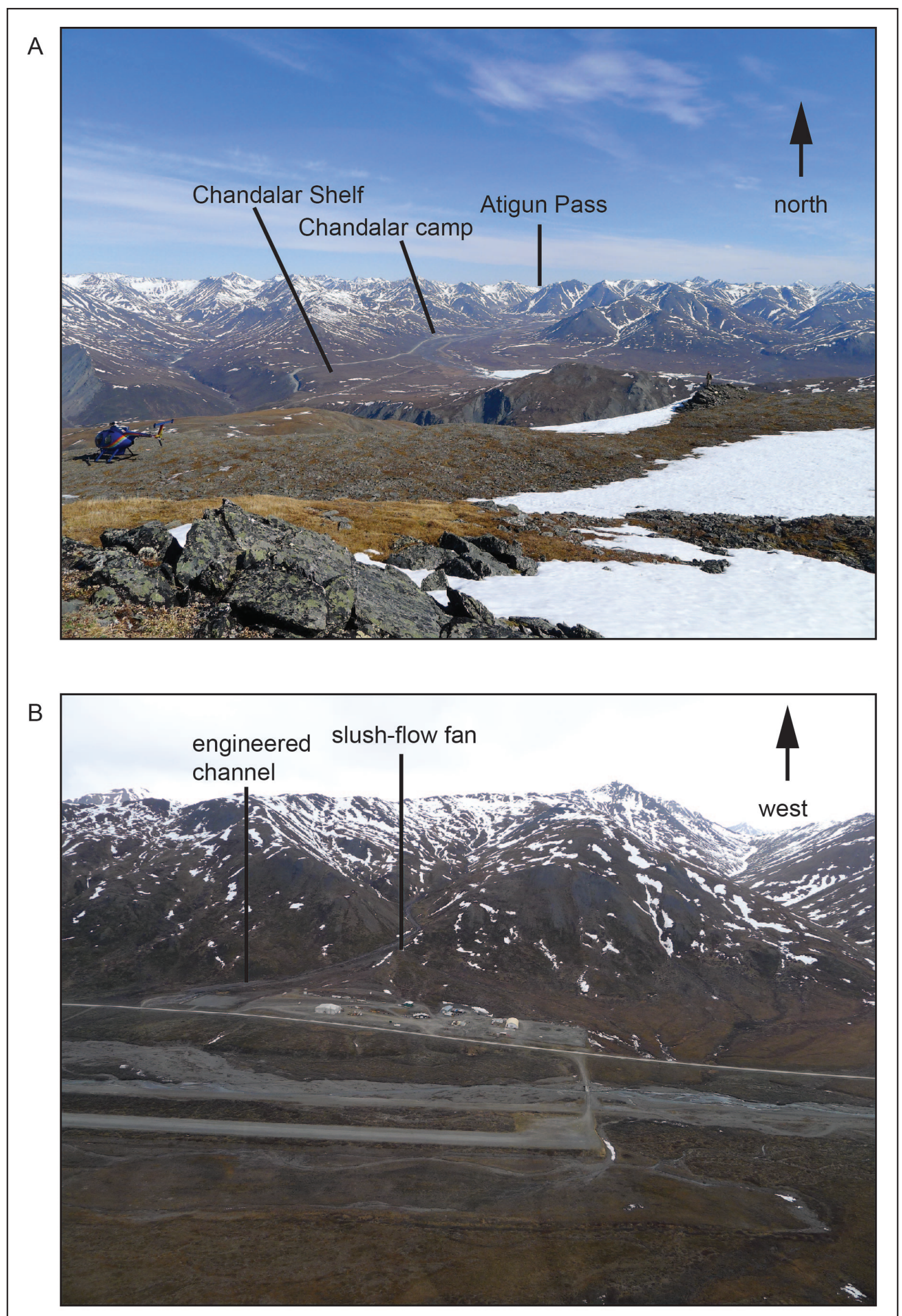

Figure 31. A. Looking north down U-shaped valley extending from the Chandalar shelf to Atigun Pass. B. View toward the west of active slush-flow fan at Chandalar Camp. Note engineered channel along south margin of fan installed to divert slush flows away from camp installments. 


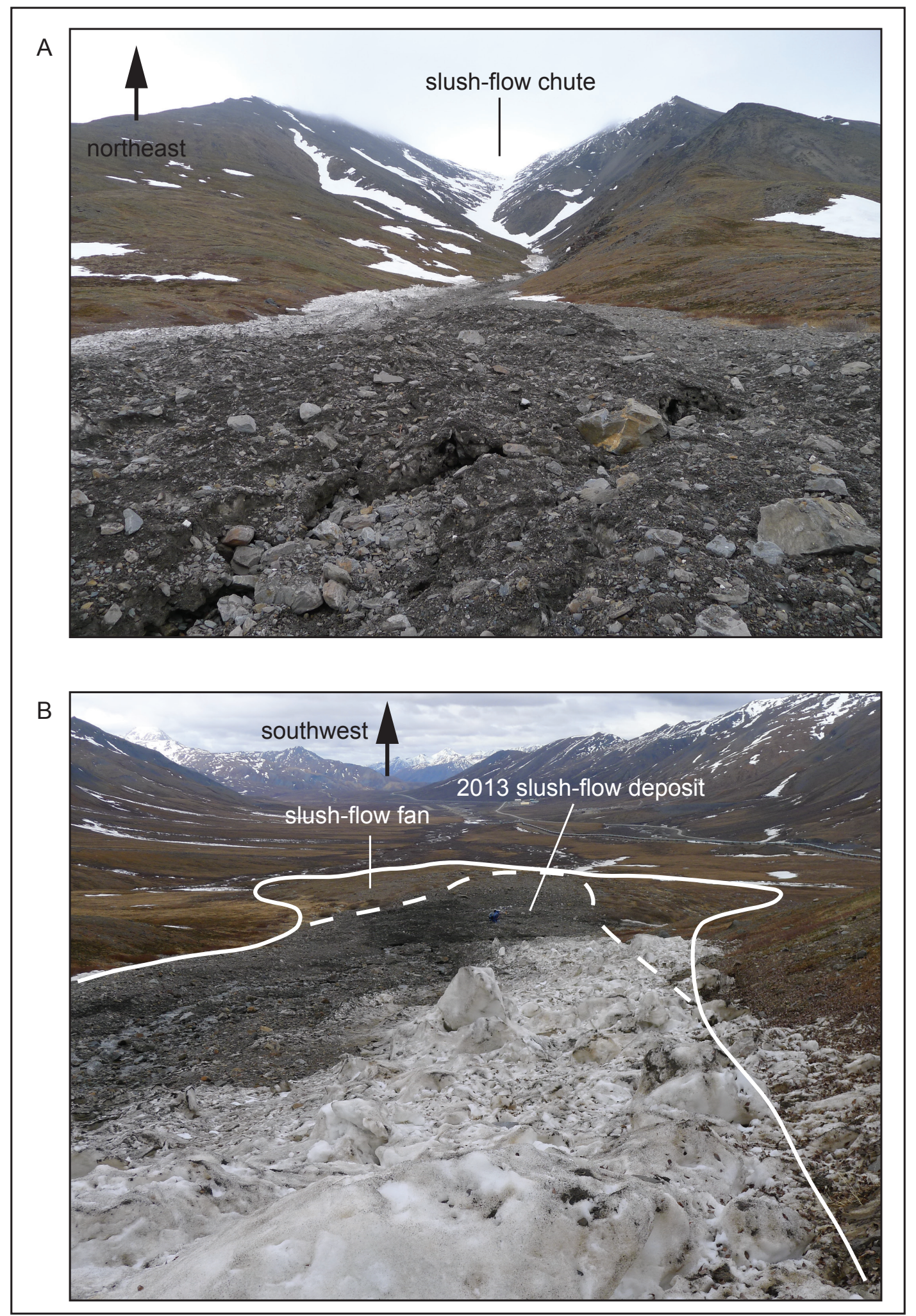

Figure 32. A. View to the northeast of slush-flow chute that released snow, blocks of ice, and large boulders in spring 2013. B. View to the southwest of slush-flow fan (outlined by solid white line) and 2013 deposit (dashed white line). Helicopter in upper center of photograph for scale. 
the Philip Smith Mountains A-5 and A-4 quadrangles). In the valley the corridor crosses lower slopes of frozen colluvium and Itkillik till. Several tributary valleys in the western valley wall produce slush flows. From the Atigun Camp site northward $3.3 \mathrm{mi}$ to the short $(-0.2 \mathrm{mi})$ crossing of the Atigun River, the corridor continues across Itkillik glacial deposits, colluvial and alluvial fans, and debris and avalanche cones (fig. 33A). Thick stream icings form annually in the vicinity of the highway bridge over the Atigun River. The eastern valley wall along the entire stretch of the upper Atigun River valley to the Atigun River highway bridge is characterized by nearly continuous, coalescing, coarse-grained debris-flow and snowavalanche cones.

North of the Atigun River highway bridge for about $13 \mathrm{mi}$ to Pump Station 4 the valley widens and the corridor continues across frozen Itkillik glacial drift, thin till over ice-scoured bedrock, coalescing colluvial and alluvial fans, and low fluvial terraces of the Atigun River (fig. 33B). Alluvial fans are typically large and granular. The colluvial fans were deposited by debris flows and snow avalanches that discharged during spring breakups and brief summer storms from the mouths of steep tributary valleys. Debris-flow deposits are also present on the proximal surfaces of granular alluvial fans. The proximal surfaces of debris-flow fans on both sides of the Atigun River are laced with cross-cutting, cobble and boulder, naturallevee ridges that confine central channels with U-shaped cross profiles (Kreig and Reger, 1982, pl. 24). Middle fan surfaces typically are covered with scattered cobbles and boulders; coarse levee ridges are less common. Distal fan surfaces are underlain by fine-grained sediments representing the matrix materials of debris slurries that were deposited upfan. During our tour of the Atigun River valley on June 3, 2013, several colluvial fans displayed evidence of fresh debris flows.

Pump Station 4 is built on a low limestone knob $-0.3 \mathrm{mi}$ west of the highway. Beginning about 3 mi south of Pump Station 4 to near the western entrance to the Atigun River gorge and Galbraith Lake, the course of the Atigun River meanders tightly. Holocene eolian and lacustrine sands are present in low terraces on either side of the Atigun River. The sands were deposited in a late Itkillik meltwater lake impounded behind the arcuate Itkillik terminal-moraine complex 3-4 mi northwest of the entrance to the Atigun River gorge (Hamilton, 1978b, 2003). Hamilton (1978b) mapped sandy lake deposits beneath the valley floor as far as $12 \mathrm{mi}$ upvalley from the modern shore of Galbraith Lake. Near the Dalton Highway we identified several linear, aligned scarps cutting across the toes of fans and Itkillik drift that are likely related to a former lake shoreline at $-2,700 \mathrm{ft}(823 \mathrm{~m})$ elevation.

On the floor of the Atigun River valley south of Galbraith Lake the near-surface lacustrine sands and eolian sands deflated from them are frozen and contain up to 15 percent visible ground ice (Hamilton, 1978b; Kreig and Reger, 1982, pl. 25). Thermokarst badlands, characterized by irregular topography, parabolic dunes, and numerous thermokarst ponds, expanding kettle lakes, and bimodal failures, are developing in these sediments (fig. 34) or recently became quasi-stabilized (Kreig and Reger, 1982, pl. 25). Kettle lakes with steep, unvegetated, slumping margins likely result from the slow melting of buried glacial ice preserved in the cold permafrost since the end of the last major (Itkillik) glaciation (Hamilton, 2003). Kreig and Reger (1982) characterized these bimodal failures and described two distinctive modes of movement: (1) a steep, rapidly receding (3-7.9 in/day [76-201 $\mathrm{mm} /$ day]) thawing ablation face in lacustrine sand and eolian sand with thin, interlayered, woody peat, and (2) a flowing tongue of thawed, + saturated soil slurry that slopes 2-8 degrees away from the scarp and moves at rates of 2.4-3.9 in/day (61-99 mm/ day). Meltwater from the thawing ice-rich head scarp saturates soils that accumulate at the base of the steep face, producing the flowing slurry tongue. Blocks of surface soil and organic mat that fall from the steep head scarp onto the slurry tongue are 


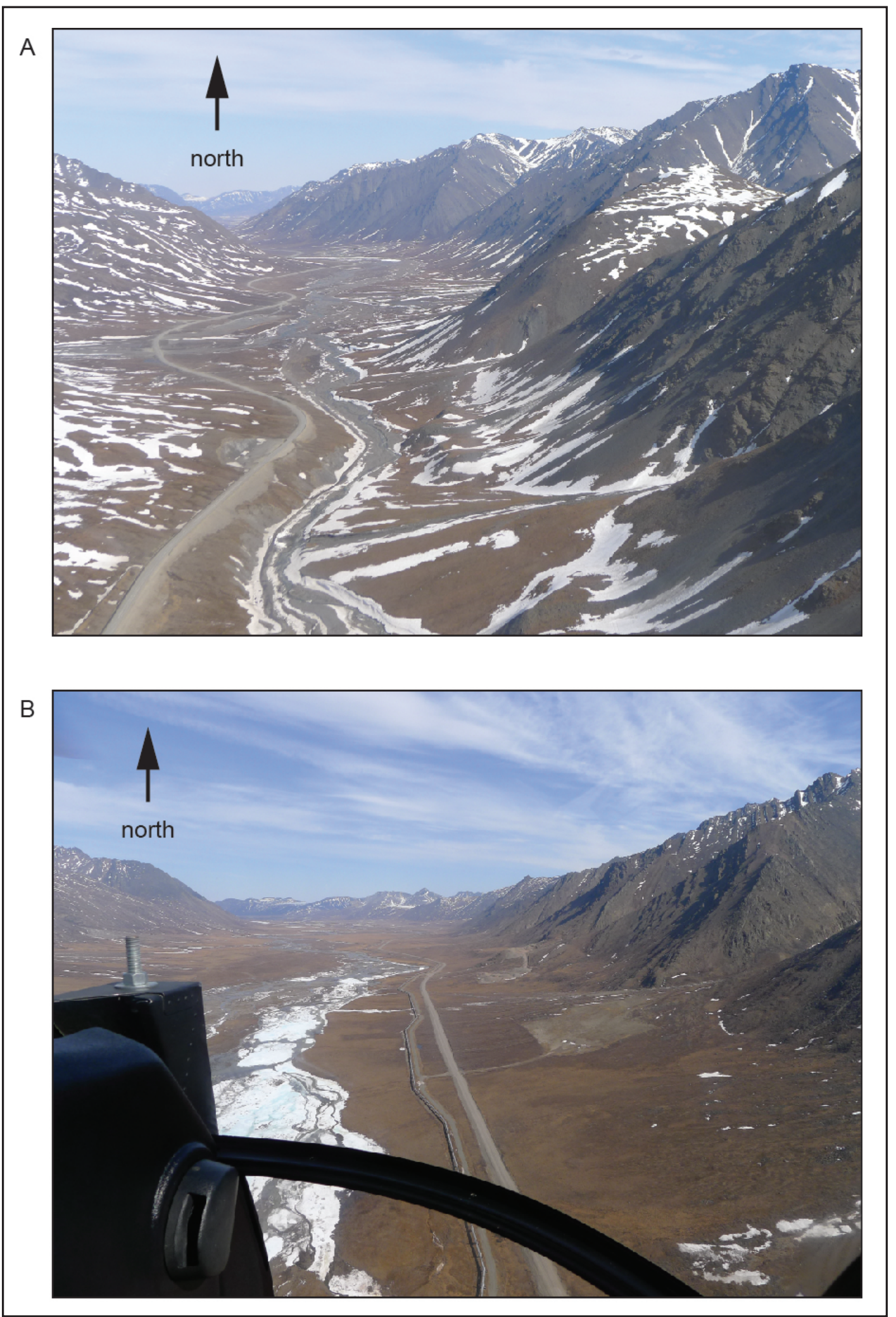

Figure 33. A. Looking north toward the upper Atigun River south of the Atigun River bridge on the Dalton Highway. Coalescing coarse-grained debris flows and avalanche cones characterize the eastern valley wall, and colluvial and alluvial fans characterize the western valley wall. B. Looking north toward the Atigun River valley north of the Atigun River bridge, showing coalescing colluvial and alluvial fans and low fluvial terraces of the Atigun River. 


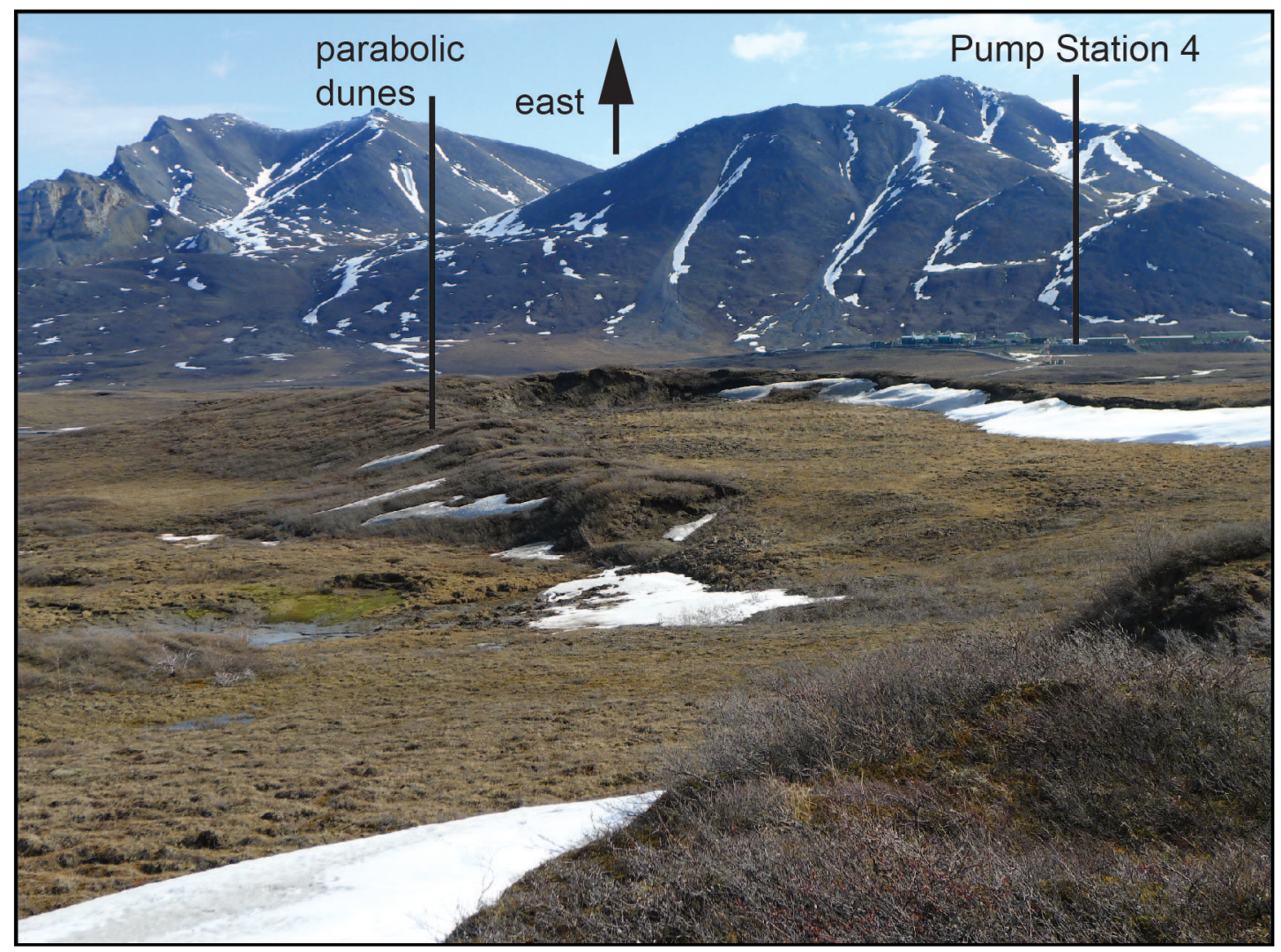

Figure 34. View, looking east, of bimodal failures in parabolic dunes west of Pump Station 4, south of Galbraith Lake.

removed, promoting scarp retreat that continues until ice-poor soils are encountered.

The Lisburne Limestone forms cliffs in the eastern and western valley walls near Galbraith Lake. Karst caves that formed in this massive limestone are clearly visible from the valley floor.

\section{Atigun River Gorge to Kuparuk River}

\section{PHILIP SMITH MOUNTAINS B-4, B-5, AND C-5 QUADRANGLES, 1:63,360 SCALE}

From the mouth of the Atigun River gorge the corridor proceeds $13.4 \mathrm{mi}$ northwest to the Toolik Lake Camp vicinity (northwest corner of sheet 4, map 10). In this section, the corridor extends across probable fine-grained lake sediments of the late Itkillik glaciation on lower slopes and along the east lateral moraine built during the Itkillik glaciation of the Atigun River valley (Hamilton, 2003) above $-2,700 \mathrm{ft}(823 \mathrm{~m})$ elevation to the outer edge of the moraine. Several borings demonstrate that silty clays and clayey silts deposited in the former meltwater lake range in thickness from 12 to $38 \mathrm{ft}$ (3.7 to $11.6 \mathrm{~m}$ ) and are ice rich (Kreig and Reger, 1982, pl. 25). About $6.0 \mathrm{mi}$ north of the mouth of Atigun River gorge, a 0.9-mi-long expanding kettle lake at $2,892 \mathrm{ft}(881 \mathrm{~m})$ elevation likely is fed by the melting of buried glacial ice of the late Itkillik glaciation. A 4.4-mi-long strip of lag boulders inside and below the crest of the Itkillik lateral moraine is present $12.7 \mathrm{mi}$ north of the mouth of the Atigun River gorge. Hamilton (2003) attributed the surface boulder lag to meltwater washing, which removed the fine fractions and eroded a series of northwest-trending drainage channels.

The topography of the east Itkillik lateral moraine consists of high-relief morainal crests, numerous irregular kettle lakes, sharp boundaries, clear relations to associated outwash, and slight 
modification by slope processes. East of the Itkillik lateral moraine (site 192, sheet 4, map 10, Lat./ Long. 68.6369, -149.5417) the corridor extends northeast $2.9 \mathrm{mi}$ to the narrow crossing of the Kuparuk River. There it extends across topography that abruptly changes to a smoother, lowrelief morphology associated with the older Sagavanirktok River lateral moraines (site 194, sheet 4, map 10, Lat./Long. 68.6614, -149.3714). Erratic boulders are more common on Itkillik moraines than on Sagavanirktok River moraines, although an exception is a lag-boulder fan on the Sagavanirktok River moraine at the head of several drainage channels directed northeast toward the Kuparuk River. Sagavanirktok River moraines exhibit relief only as local clusters of low hills and ridges composed of till. Surrounding moraine surfaces are well rounded by blanket solifluction, which is very vigorous in the thin active layer on the frozen slopes north of the Brooks Range. Surfaces also have complex fillings of thermokarst basins associated with yedoma in ice-rich eolian and glacial deposits.

\section{Kuparuk River to Happy Valley}

PHILIP SMITH MOUNTAINS C-4, D-4, AND

D-3 AND SAGAVANIRKTOK A-3 AND A-4

QUADRANGLES, 1:63,360 SCALE

From the Kuparuk River the corridor continues northeastward across solifluctionrounded morainal ridges of the penultimate (Sagavanirktok River) glaciation for $8.9 \mathrm{mi}$, crossing the Toolik River $2.5 \mathrm{mi}$ past the Kuparuk River crossing, before crossing a narrow, unnamed icemarginal drainage channel. The corridor next proceeds $-7.0 \mathrm{mi}$ along the crest of the northwestern Itkillik terminal moraine of the Sagavanirktok River lobe near Slope Mountain (Hamilton, 2003). Important archaeological sites are identified on the knobs and ridges of the Itkillik terminal moraine in this area (Dixon, 1975). The margin of the Sagavanirktok River parallels the eastern side of the moraine. Along the western side of the corridor north of Slope Mountain the low hills consist of glacial drift of the Sagavanirktok glaciation and contain prominent yedoma (fig. 35). From the northern margin of the Itkillik moraine the corridor descends onto the proximal Itkillik outwash fan and crosses it for $4.2 \mathrm{mi}$, where it abruptly intersects a Holocene fluvial terrace of the Sagavanirktok River near its junction with the Ribdon River.

Coarse gravels of the low Holocene terraces and the river floodplain are discontinuously frozen close to the active river channel where flooding is annual, and the floodplain is unvegetated or supports low willow shrubs and a ground cover of lichens and mosses (Kreig and Reger, 1982, pl. 28). Elsewhere the floodplain is continuously frozen and infrequently flooded.

From the junction of the Sagavanirktok and Ribdon rivers the corridor follows the fairly flat Sagavanirktok River floodplain for about $4 \mathrm{mi}$ before ascending onto frozen upland deposits of the penultimate (Sagavanirktok River) glaciation near the small alluvial fan at the mouth of Gustafson Gulch. From there northward for -21 mi to near Happy Valley, the corridor continues across ridges and small drainages in the drift of the Sagavanirktok River glaciation. Original morainal topography is all but obliterated by long-term, very active solifluction in the foot-deep, seasonally thawed soil layer above continuous permafrost. Only scattered, small clusters of low till knobs stand above surrounding rounded, smooth ridges and slopes that are ubiquitously covered by sedge tussocks. Shallow horsetail drainages channel the copious early summer runoff from snowmelt and thawing of the thin active layer from upland surfaces into local basins and tributary streams. Lowlands in Sagavanirktok River moraines are occupied by scattered kettle lakes with outlines considerably altered by partial filling with solifluction colluvium. Also present are deep thaw basins associated with yedoma that contain frozen, icerich fills of peat and silty colluvium $>5 \mathrm{ft}(>1.5$ m) thick (Kreig and Reger, 1982, pl. 28; Kanevskiy and others, 2011). Active yedoma basins contain meltwater ponds and lakes with ice-rich sidewalls that are steep, unvegetated, and unstable. On 


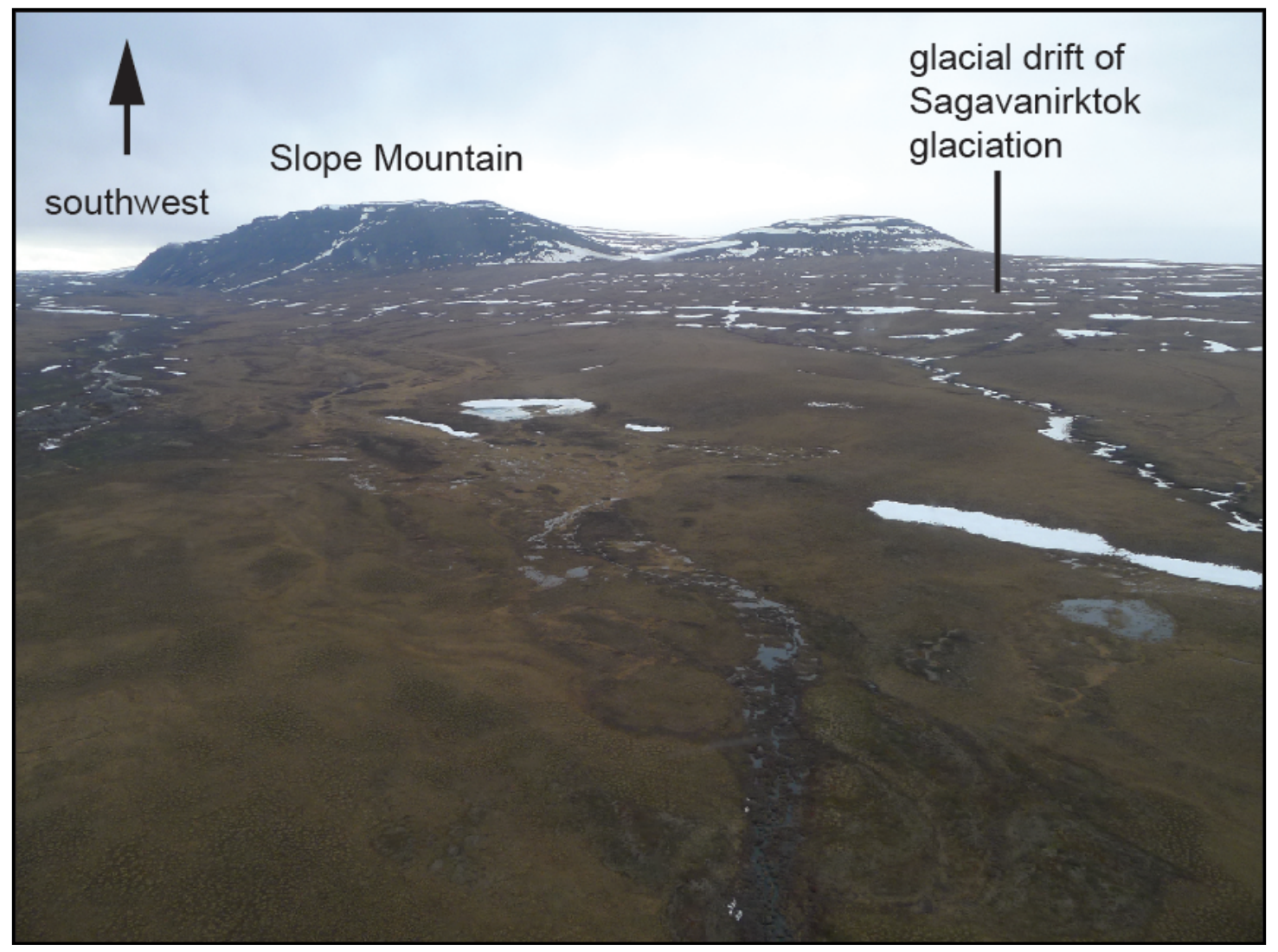

Figure 35. Photograph, looking southwest, of glacial drift of the Sagavanirktok glaciation extending north of Slope Mountain. Margins of lateral moraines are highlighted by snow.

middle and upper slopes, active bimodal failures produce elongate scars that become stabilized and vegetated when receding, steep thaw faces encounter ice-poor conditions.

Northward from the alluvial fan at the mouth of Gustafson Gulch in Philip Smith D-4 Quadrangle the corridor extends across low fluvial terraces and the Sagavanirktok River floodplain. Narrow solifluction-debris aprons are present along the margin of the river at the base of Cretaceous siltstone and shale bluffs that are overlain by icerich till of the Sagavanirktok River glaciation. Local borings in the till and observations in a nearby fresh roadcut in the Sagavanirktok A-4 Quadrangle (Site 198, sheet 4, map 11, Lat./Long. 69.0224, -148.8418) indicate that the upper 25-40 ft (7.6$12.2 \mathrm{~m}$ ) of the till contains -75 percent ground ice by volume, including large, foliated ice wedges (33 percent) separated by reticulated ice that forms lenses, pods, and rinds of ice around individual clasts (67 percent) in frozen till (Kreig and Reger, 1982, pl. 28, fig. 13). A vegetated, 0.6-mi-wide bimodal failure scar is present at the top of the bedrock bluff.

\section{Happy Valley area to Sagwon Bluffs area (TAPS Pump Station 2)}

SAGAVANIRKTOK A-3, A-4, AND B-3

QUADRANGLES, 1:63,360 SCALE

The maximum extent of the Sagavanirktok River glaciation in this drainage is $-7.3 \mathrm{mi}$ north of Happy Valley Camp in the northeastern corner of the Sagavanirktok A-3 Quadrangle (Detterman and others, 1958; Hubbard, 2016). Sagavanirktok glacial surfaces outside the bounds of the corridor are characterized as a colluvium- and till-covered upland. North of Happy Valley Camp the corridor follows the braided Sagavanirktok River floodplain for about $22 \mathrm{mi}$ to its confluence with the 
Ivishak River (fig. 36A). The floodplain is underlain by coarse alluvium in a closed talik in continuous permafrost. Water from the talik beneath the floodplain is the source of extensive stream icings that gradually thicken on the floodplain each winter. The annual breakup, which is the dominant hydrologic event of the year, occurs in late May to early June, when sudden warming air temperatures cause widespread snowmelt and meltwater runoff on upland surfaces. The result is an abrupt increase of river discharge across the ice-filled floodplain (Scott, 1978; Updike and Howland, 1979). Initial flood surges flow on ice sheets and many are temporarily diverted onto low terraces that are above normal flood levels. Numerous ice slabs are torn from the disintegrating ice sheets by the flood surges and are scattered down the Sagavanirktok River floodplain. The 2015 Sagavanirktok River breakup flood was exceptionally extensive, inundating the Dalton Highway for several weeks and ultimately breaching it, severely impacting surface resupply of the North Slope petroleum fields. Once the ice sheets melt, the floodplain alluvium remains frozen and the river typically returns to its previous course. Changes in channel location on the floodplain occur only after the floodplain and bank sediments have thawed and river discharges are adequate to move the coarse alluvium (Scott, 1978). Floodplain expansion occurs when frozen bank sediments are undercut by thermoerosion niching and blocks of bank material fall into the channel (Kreig and Reger, 1982, pl. 29).

The Sagwon Bluffs occupy the western side of the corridor from about $9 \mathrm{mi}$ north of Happy Valley to west of the junction of the Sagavanirktok and Ivishak rivers. Bedrock in the bluffs (fig. 36B) consists of north-dipping, upper Cretaceous nonmarine sedimentary rocks (conglomerate, sandstone, siltstone, carbonaceous shale, and coal) (Mull and Adams, 1989) that are thinly overlain by colluvium and possibly by discontinuous deposits of the Anaktuvuk River glaciation of early Pleistocene age in the lowlands (Hubbard, 2016). The surface of the bluffs is characterized by rounded upland ridges and slopes and small drainages (fig. 36B). Along the northern side of the bluffs the corridor descends for $0.5 \mathrm{mi}$ across a colluvial-alluvial fan to a low terrace of the Sagavanirktok River. Solifluction fans and aprons flow from uplands onto inner terrace surfaces (Kreig and Reger, 1982, pl. 26).

\section{Sagwon Bluffs (TAPS Pump Station 2) to TAPS Pump Station 1}

SAGAVANIRKTOK B-3, C-3, D-3, AND D-4

AND BEECHEY POINT A-3, A-4, AND B-3

QUADRANGLES, 1:63,360 SCALE

The final $-62 \mathrm{mi}$ section of the corridor extends to the north of the Arctic Foothills and crosses floodplains, low fluvial terraces, and the Arctic Coastal Plain. North of Sagwon Bluffs the floodplain of the Sagavanirktok River widens and becomes anabranched, and near the Beaufort Sea coast the floodplain splits into distributaries on a broad fan delta. Waters in the alluvial fill of the closed talik beneath the Sagavanirktok River gradually become more saline downstream in response to saltwater invasion from the Beaufort Sea. The Sagavanirktok River has incised the higher coastal-plain surface and the floodplain consists of numerous low terraces (fig. 37). Terrace treads are covered by $1-8 \mathrm{ft}(0.3-2.4 \mathrm{~m})$ of frozen sandy silt covering alluvium overlying bedload sand and gravel, and are separated from lower floodplain surfaces by steep, 3- to 8-foothigh (0.9- to 2.4-m-high) erosional scarps (Kreig and Reger, 1982, pl. 29). Shallow stream channels form anastomosing networks on terrace treads and contain sandy gravel fills overlain by up to $8 \mathrm{ft}(2.4$ $\mathrm{m}$ ) of frozen lowland loess and silty sand cover sediments. Former stream channels contain small, shallow, irregular thaw lakes that postdate the surrounding terrace and string fens with complex, low vegetation ridges oriented perpendicular to the local surface drainage. These channels and nearby terrace treads are infrequently inundated during breakup flood surges that are temporarily diverted from normal stream channels by thick seasonal 


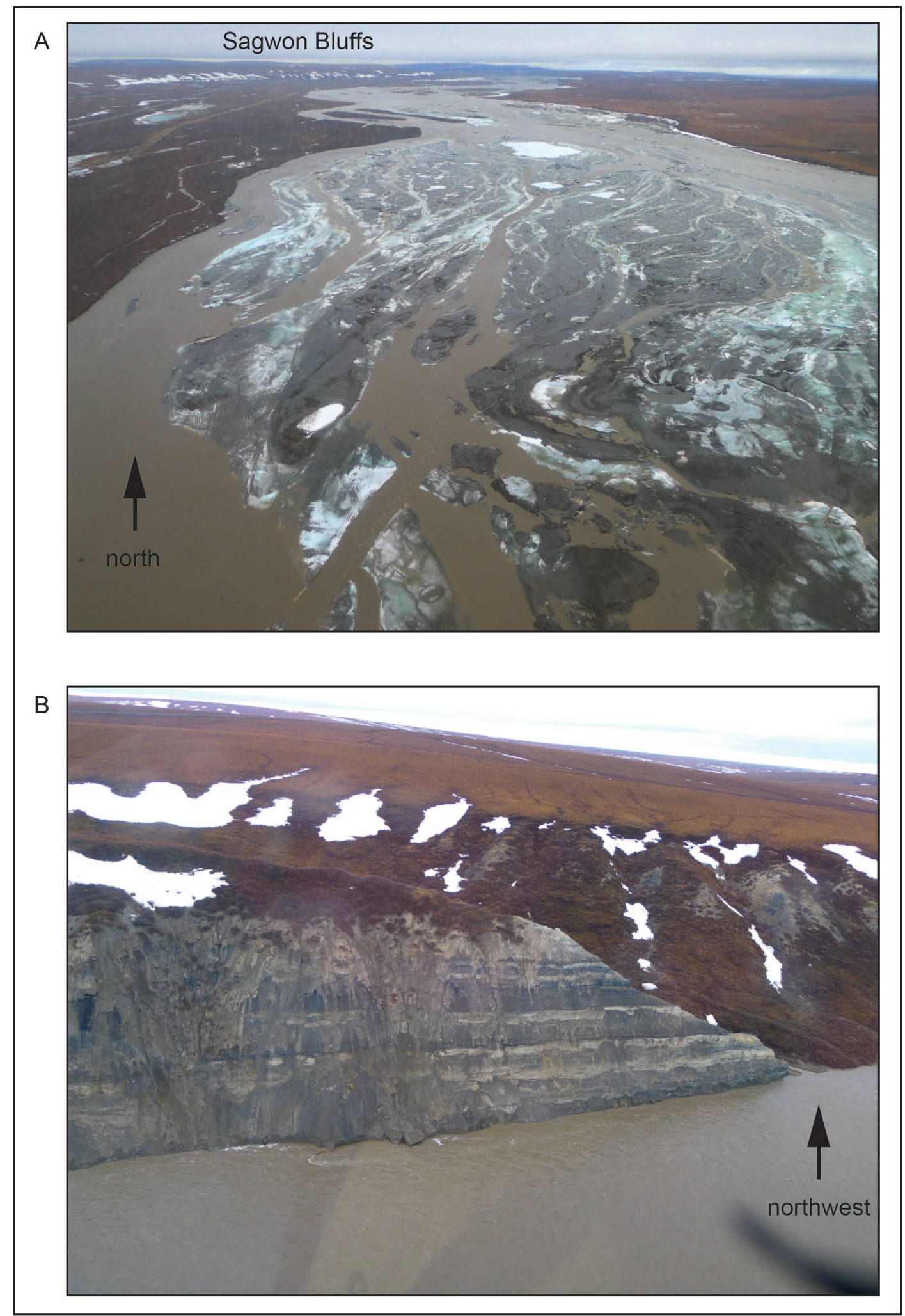

Figure 36. A. View, looking north, of braided channels of the Sagavanirktok River floodplain south of its confluence with the Ivishak River, showing extensive stream icing. Sagwon Bluffs are in the background on the upper left. B. View, looking northwest, of Cretaceous bedrock exposed in the Sagwon Bluffs. The rounded upland ridges and slopes that cap the bluffs are underlain by thin colluvium and possibly discontinuous deposits of the Anaktuvuk River glaciation. 


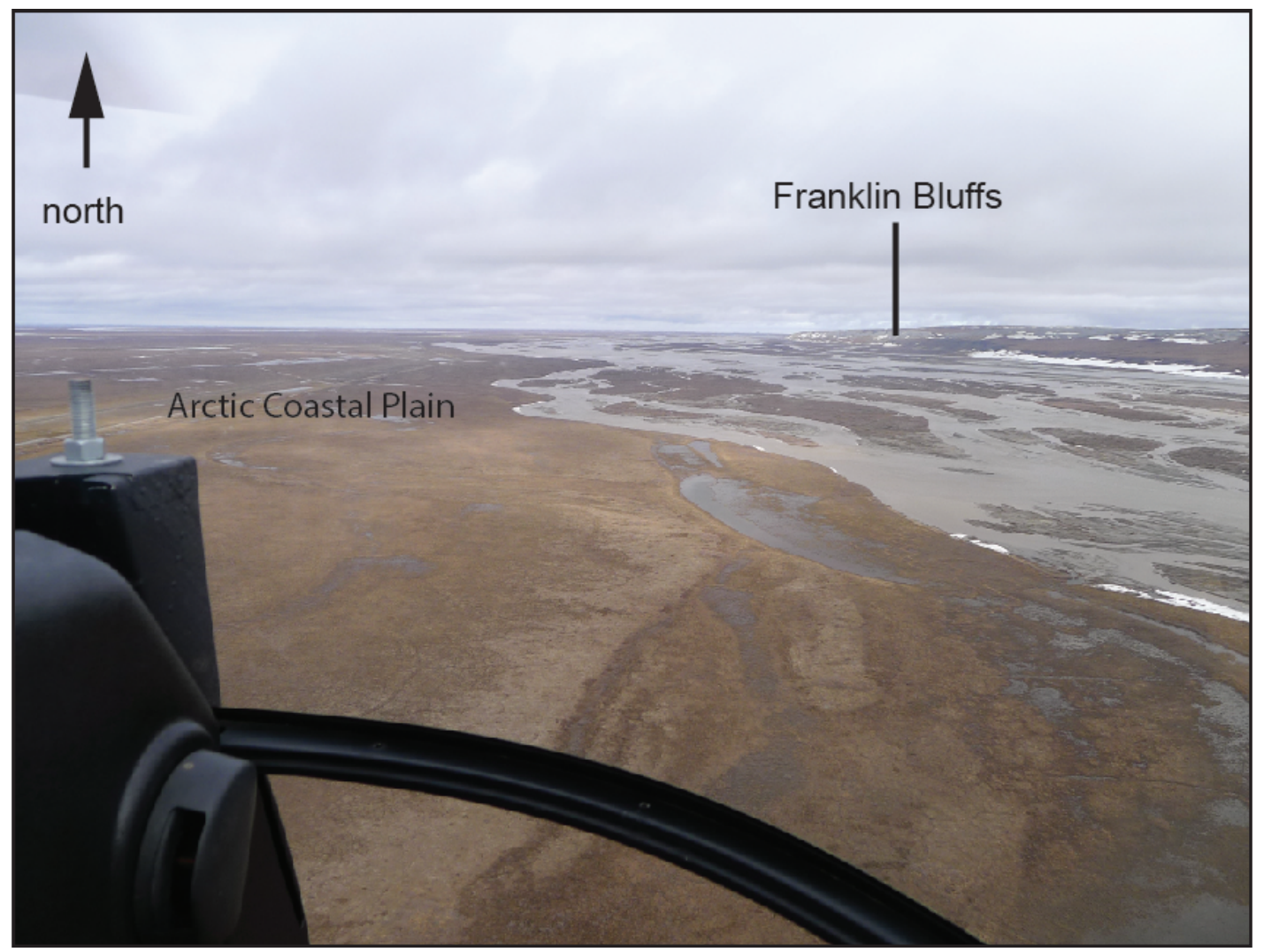

Figure 37. View, to the north, of the Sagavanirktok River near Franklin Bluffs, where it has incised the Arctic Coastal Plain. The floodplain is characterized by numerous low terraces covered by frozen sandy silt cover sediments.

icings. Ice wedges form simple polygonal patterns on interchannel surfaces of young terraces and more complex polygons on older terraces. Microrelief features on terrace treads near floodplains are typically buried by eolian sand blankets and belts of low sand dunes.

The coastal plain slopes gently northward to the Beaufort Sea coast and, although it is crossed by several small streams that are separated by low interfluves, it is poorly drained because slopes are gentle and shallow, and continuous permafrost impedes subsurface drainage. Perennially frozen ground is up to $-2,000 \mathrm{ft}(610 \mathrm{~m})$ thick beneath the Arctic Coastal Plain and is colder (< $-5^{\circ} \mathrm{C}$ ) than permafrost farther south (Ferrians and others,1969; Jorgenson and others, 2008). The ground surface is underlain by $3-12 \mathrm{ft}(0.9-3.7 \mathrm{~m})$ of frozen thaw-lake deposits, organic sediments, and lowland loess that overlie ice-rich coastal-plain sands and gravels (Kreig and Reger, 1982, pl. 29). Pingos are common landforms on the coastal plain (fig. 38A). Tussocks, frost scars, and spot medallions universally cover interfluve surfaces as a result of seasonal freezing and thawing, and complex ice-wedge polygons typically develop in perennially frozen sediments on lower slopes and in basins (fig. 38B). They also form locally on bedrock ridges. Ice-wedge polygons have low centers where unaffected by thermokarst processes, but have high centers where affected by thawing of near-surface permafrost along scarps bordering floodplains, lakes, and the Beaufort Sea. Where small surface streams intersect ice-wedge complexes, pools form at wedge intersections and expand by melting the underlying foliated ice and short, straight channels connect the pools along ice wedges, forming beaded drainage patterns. 


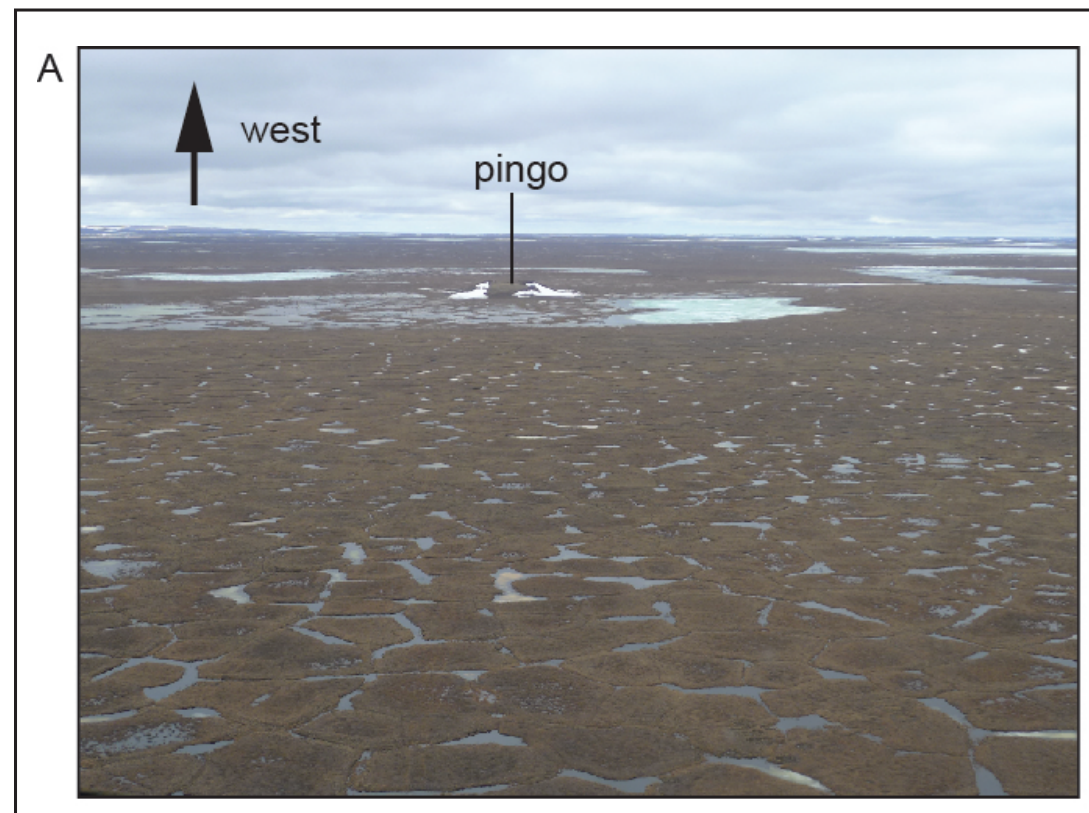

$\mathrm{B}$
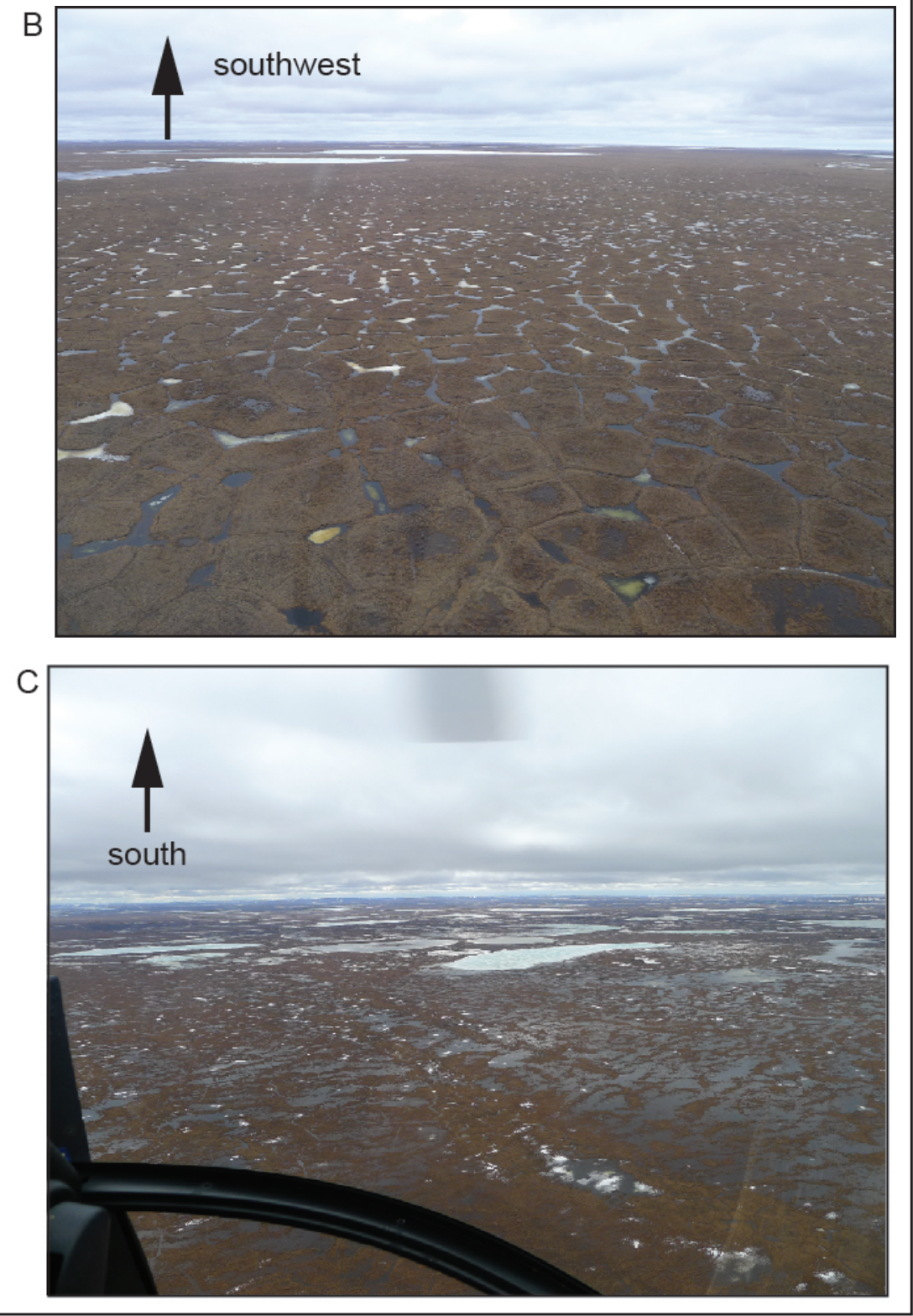

Figure 38. Photographs illustrating landforms on the Arctic Coastal Plain west of Franklin Bluffs. A. Pingo and polygonal ground. B. Thick tussocks and complex ice-wedge polygons. C. Oriented thaw lakes, typically elliptical and oriented north-northwest. 
Shallow thaw lakes are ubiquitous on the coastal plain (fig. 38C), where they occupy square to elliptical basins with long axes dominantly oriented north-northwest, perpendicular to dominant summer winds (Black and Barksdale, 1949; Carson and Hussey, 1962; Sellmann and others, 1975). Near-surface, sun-warmed lake currents propelled by surface winds preferentially thaw the permafrost on the downwind ends of the lake basins and erode unfrozen sediments along the lake shores. Shorelines are steep, unstable, and scalloped where lakeside sediments are ice rich. Closed taliks exist beneath thaw lakes that are $>6 \mathrm{ft}(>1.8 \mathrm{~m})$ deep, and the thickness of the thawed zone beneath the lakes is a function of lake size. Taliks are deeper beneath larger lakes and reach depths of $>100 \mathrm{ft}(>30.5 \mathrm{~m})$. Shallower lakes freeze to the bottom each winter, and taliks are not present. Lake basins that are intersected by headward-extending small streams drain suddenly, exposing their organic-rich, fine-grained fills. Typically, submerged shelves, separated by deep central troughs, are exposed on east and west sides of lake basins as water levels drop. Fills in drained lake basins freeze from the surface down and from the surrounding permafrost inward, ultimately forming small, steep-sided closed-system pingos by doming of near-surface sediments through the local development of high groundwater pressures and the growth of an ice or icesediment core (Mackay, 1979). Map studies of the Arctic Coastal Plain from the Sagavanirktok River -32 mi westward demonstrate that 97.3 percent of the steep-sided pingos in the Prudhoe Bay area occupy lake basins or possible lake basins (Walker and others, 1985). Dating of several steep-sided, closed-system pingos on the Arctic Coastal Plain demonstrates their Holocene ages.

Drifting snow along elevated sections of the TAPS on the coastal plain insulate the underlying

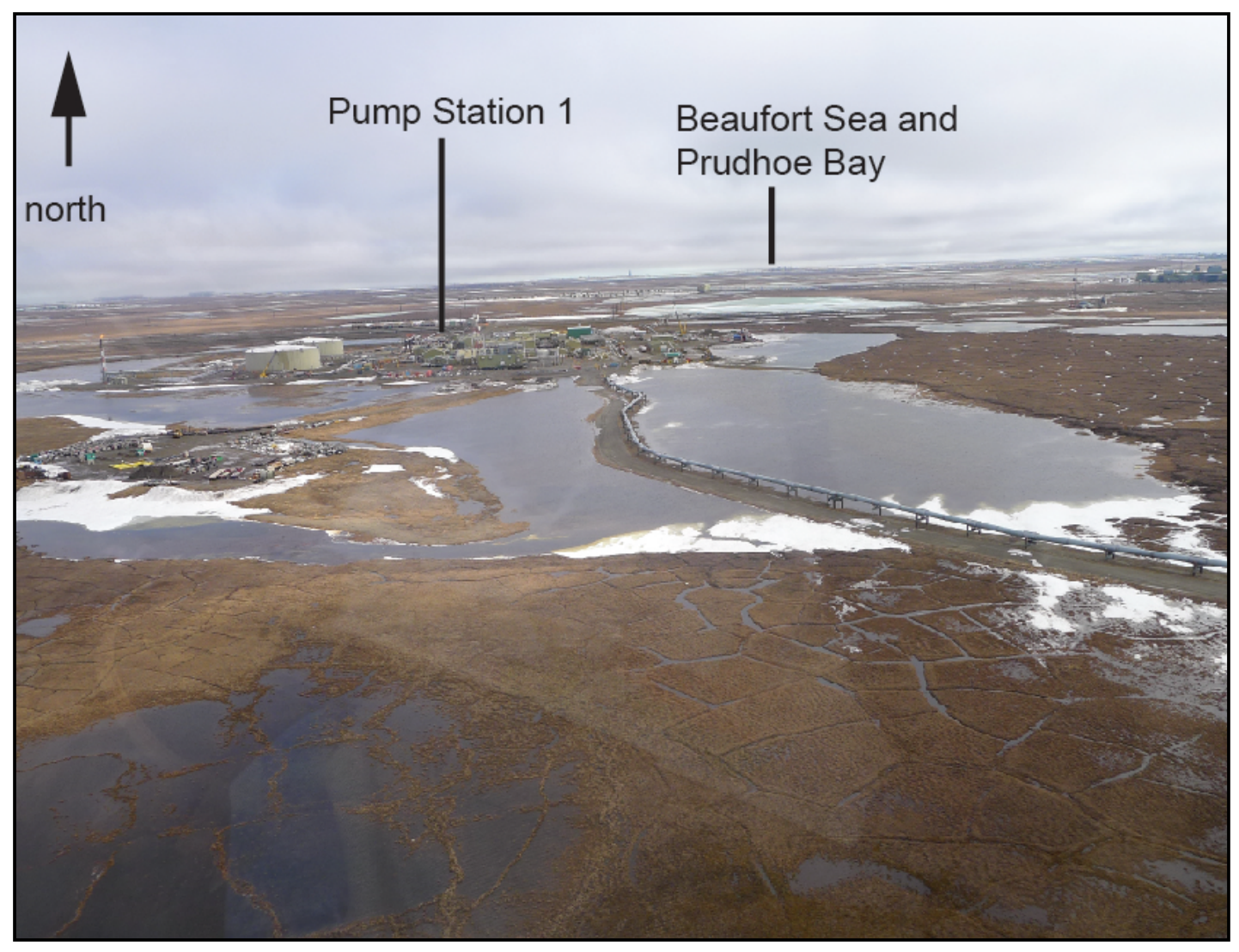

Figure 39. Looking north toward Pump Station 1, near the northern end of the infrastructure corridor. The Beaufort Sea and Prudhoe Bay are in the background. 
shallow permafrost, warming it and causing pipeline maintenance problems.

The Putuligayuk River floodplain, a major source of aggregate for oil field construction, is crossed for $1.9 \mathrm{mi}$. The northern end of the corridor extends approximately $5 \mathrm{mi}$ northeast of Pump Station 1, where it intersects the Beaufort Sea at Prudhoe Bay (fig. 39).

\section{SUMMARY}

Between 2011 and 2013 DGGS evaluated landscape geomorphology and geologic hazards in an -700-mi-long by $\sim 1$-mi-wide infrastructure corridor between Cook Inlet and Prudhoe Bay. In general, the corridor follows the Parks Highway from the Susitna Lowland to Nenana, extends across the margin of the Minto Flats basin and Tolovana Valley between Nenana and Livengood, and follows the Dalton Highway from Livengood to Prudhoe Bay. The investigations involved office-based analysis of aerial photographs, satellite imagery, lidar-derived topographic data, and helicopter surveys and ground reconnaissance. The results presented represent a qualitative inventory of geomorphic landforms and geologic hazards present in 17 geographic subsections and are summarized in table 2.
The landscape geomorphic and geologic hazard observations summarized in this report provide information that can be used to guide the planning, design, and construction of infrastructure projects along an important corridor. The integration of imagery, lidar-derived products, and field reconnaissance has proven to be an effective means for interpreting geomorphology and assessing geologic hazards over large areas. These methodologies could be similarly applied to other infrastructure corridors in Alaska and elsewhere.

\section{ACKNOWLEDGMENTS}

The authors acknowledge field and office technical assistance from DGGS staff including Rachel Frohman, Alexander Gould, James Weakland, Mike Hendricks, Patricia Gallagher, Joni Robinson, Paula Davis, Kristen Janssen, and Simone Montayne. Additionally, we are grateful for safe transport to and from remote field localities by Pathfinder Aviation, Inc., Prism Helicopters, and Quicksilver Air, Inc. This project was completed through a reimbursable services agreement between DGGS and the Alaska Gasline Development Corporation (AGDC). We appreciate peer review comments by Gabriel Wolken and Patty Burns that improved the manuscript. 
Table 2. Summary of potentially important geologic hazards present in each sub-section of the corridor. Sub-sections are listed consecutively from south to north, consistent with the text.

\begin{tabular}{|c|c|c|}
\hline $\begin{array}{l}\text { Infrastructure } \\
\text { corridor } \\
\text { geographical } \\
\text { subsection }\end{array}$ & $\begin{array}{l}\text { Common geomorphic landforms } \\
\text { and deposits }\end{array}$ & Potential geologic hazards \\
\hline Carpenter Lake to Willow & $\begin{array}{l}\text { Glacial moraine, glacial outwash plain, small lake } \\
\text { basins, string bogs, sand dune complexes, fluvial } \\
\text { terraces, fault scarps (west of Elmendorf terminal } \\
\text { moraine) }\end{array}$ & $\begin{array}{l}\text { High water table, swampy surficial } \\
\text { materials, liquefaction, surface fault } \\
\text { rupture, landslides }\end{array}$ \\
\hline Willow to Sheep Creek & $\begin{array}{l}\text { Pitted outwash, alluvial outwash terraces, glacial } \\
\text { moraines, ice-stagnation deposits, oxbow lakes }\end{array}$ & $\begin{array}{l}\text { Rotational slope failures, earth flows, } \\
\text { earth falls, lateral spreads, flooding, } \\
\text { failures of terrace risers }\end{array}$ \\
\hline $\begin{array}{l}\text { Sheep Creek to } \\
\text { Chulitna Butte }\end{array}$ & $\begin{array}{l}\text { Outwash alluvium, ice-stagnation esker-kame com- } \\
\text { plexes, glacial till, kettle lakes, glacial moraine, aban- } \\
\text { doned meltwater channels, glaciolacustrine, fluvial } \\
\text { terraces, fluted ground moraine, floodplain bars, sand } \\
\text { dunes, string bogs, alluvial fans, ice-scoured bedrock }\end{array}$ & $\begin{array}{l}\text { Failures of terrace risers, flooding, gul- } \\
\text { lying, debris flows, seasonal stream } \\
\text { icings, large landslides in till }\end{array}$ \\
\hline $\begin{array}{l}\text { Chulitna Butte to } \\
\text { the vicinity of Ferry }\end{array}$ & $\begin{array}{l}\text { Glacial till, braided channels, meander belts, fluvial } \\
\text { terraces, alluvial fans, grooved upland surface, shal- } \\
\text { low bedrock with thin till, glacially scoured bedrock, } \\
\text { ice-rich peat mounds (palsas), floodplains, fault } \\
\text { scarps, blocky slope colluvium, pitted-outwash } \\
\text { terraces, fine-grained glaciolacustrine deposits } \\
\text { (locally frozen and ice rich), faults }\end{array}$ & $\begin{array}{l}\text { Debris flows, gullying, landslides, rock } \\
\text { fall, high water table, discontinuous } \\
\text { permafrost, solifluction, surface fault } \\
\text { rupture, rock and debris avalanches, } \\
\text { liquefaction, subsidence of ice-rich } \\
\text { deposits, outburst floods, river scour, } \\
\text { stream icings }\end{array}$ \\
\hline Ferry to Chatanika River & $\begin{array}{l}\text { Fluvial terraces, colluvium, outwash terraces, alluvial } \\
\text { fans, sandy abandoned channels, boggy lowland, } \\
\text { coalescing piedmont fans, swamp deposits, sand } \\
\text { dunes, loess (blankets, ridges, and fans), abandoned } \\
\text { floodplains, thaw lakes, polygonal ground, } \\
\text { thermokarst pits, fault scarps }\end{array}$ & $\begin{array}{l}\text { Gullying of older outwash surfaces, rock } \\
\text { fall, ice rich, shallow permafrost, poor } \\
\text { drainage, frost jacking, surface dilation, } \\
\text { subsidence, bedrock bluff failures, } \\
\text { surface fault rupture, liquefaction, lateral } \\
\text { spread, large ground-ice masses, } \\
\text { unstable groundwater emergence zones }\end{array}$ \\
\hline $\begin{array}{l}\text { Chatanika River } \\
\text { to Hess Creek }\end{array}$ & $\begin{array}{l}\text { Fluvial lowlands, abandoned floodplains, silt- and } \\
\text { peat-filled abandoned channels, thermokarst ponds, } \\
\text { lakes, and depressions, open-system pingos, poly- } \\
\text { gonal ground, reworked silt and organic deposits, } \\
\text { alluvial fans, deep thaw basins, yedoma, oxbow lakes, } \\
\text { silty upland loess slopes (frozen), low rolling hills }\end{array}$ & $\begin{array}{l}\text { Rilling and gullying of loess slopes, } \\
\text { permafrost, frozen surficial materials, } \\
\text { thermokarst subsidence }\end{array}$ \\
\hline $\begin{array}{l}\text { Hess Creek to } \\
\text { Yukon River }\end{array}$ & $\begin{array}{l}\text { lce-rich retransported loess, lowland loess, upland } \\
\text { loess, low rolling hills, open-system pingos, coalesced } \\
\text { silt alluvial fans, yedoma, low bedrock ridges, deeply } \\
\text { eroded channels, faults }\end{array}$ & $\begin{array}{l}\text { Gullying, perennially frozen and ice-rich } \\
\text { subsurface materials, landslides, block } \\
\text { failures along the Yukon River bluff }\end{array}$ \\
\hline $\begin{array}{l}\text { Yukon River to } \\
\text { Fort Hamlin Hills }\end{array}$ & $\begin{array}{l}\text { Ice-rich fluvial terraces, flood scarps, thick, fine- } \\
\text { grained, frozen flood-basin deposits, polygonal } \\
\text { ground, thermokarst gullies and ponds, ice-rich re- } \\
\text { transported loess lowlands, floodplains, yedoma, } \\
\text { alluvial and colluvial fans }\end{array}$ & $\begin{array}{l}\text { Permafrost, gullying, frost jacking, } \\
\text { gelifluction, fine-grained debris flows, } \\
\text { thermokarst subsidence }\end{array}$ \\
\hline $\begin{array}{l}\text { Fort Hamlin Hills } \\
\text { to Jim River }\end{array}$ & $\begin{array}{l}\text { Loess-covered (thin) bedrock slopes, colluvial fans, } \\
\text { retransported loess lowlands, polygonal ground, } \\
\text { yedoma basins, fluvial terraces, retransported grus, } \\
\text { frozen silt and angular gravel mounds, thaw lakes, } \\
\text { tors, thinly covered bedrock hills with residual } \\
\text { boulders, turf-covered soil lobes, grus-filled swales } \\
\text { and gullies, ice-marginal lake deposits, glacial drift, } \\
\text { ice-scoured bedrock }\end{array}$ & $\begin{array}{l}\text { Bedrock frost weathering (weathered } \\
\text { bedrock), gravity-driven slope processes, } \\
\text { subsurface piping, gullying, solifluction, } \\
\text { bank failures along streams }\end{array}$ \\
\hline
\end{tabular}


Table 2 (continued). Summary of potentially important geologic hazards present in each sub-section of the corridor. Sub-sections are listed consecutively from south to north, consistent with the text.

\begin{tabular}{|c|c|c|}
\hline $\begin{array}{l}\text { Infrastructure } \\
\text { corridor } \\
\text { geographical } \\
\text { subsection }\end{array}$ & $\begin{array}{c}\text { Common geomorphic landforms } \\
\text { and deposits }\end{array}$ & Potential geologic hazards \\
\hline $\begin{array}{l}\text { Jim River to South } \\
\text { Fork Koyukuk River }\end{array}$ & $\begin{array}{l}\text { U-shaped bedrock trough, glacial and glaciofluvial } \\
\text { deposits, ice-scoured bedrock, colluvial and alluvial } \\
\text { fans }\end{array}$ & $\begin{array}{l}\text { Solifluction, debris flows, slush flows, } \\
\text { avalanches, rock fall, subsurface piping }\end{array}$ \\
\hline $\begin{array}{l}\text { South Fork Koyukuk } \\
\text { River to Middle Fork } \\
\text { Koyukuk River }\end{array}$ & $\begin{array}{l}\text { Glacial moraine, glacial drift and till, glacial outwash, } \\
\text { frozen glacial and ice-stagnation deposits, braided } \\
\text { fluvial floodplains and terraces, thermokarst- } \\
\text { modified kettle lakes, alluvial fans, debris flow fans, } \\
\text { faults }\end{array}$ & $\begin{array}{l}\text { Erosion of kettle lake banks, permafrost, } \\
\text { stream icings, debris flows, flooding, } \\
\text { terrace riser failures }\end{array}$ \\
\hline $\begin{array}{l}\text { Middle Fork Koyukuk } \\
\text { River to Dietrich River } \\
\text { and Table Mountain }\end{array}$ & $\begin{array}{l}\text { Glacially carved bedrock; glacial till; glacial outwash; } \\
\text { debris-flow fans; creeping frozen debris lobes, } \\
\text { benches, and tongues; fluvial terraces; fluvial } \\
\text { floodplains; alluvial and colluvial fans; thinly covered } \\
\text { bedrock; landslide blocks }\end{array}$ & $\begin{array}{l}\text { Debris flows, soil and debris creep, } \\
\text { stream icings, avalanches, rock fall, } \\
\text { deep-seated landsliding }\end{array}$ \\
\hline $\begin{array}{l}\text { Uppermost Dietrich } \\
\text { River and Table Mountain } \\
\text { to Atigun River Gorge }\end{array}$ & $\begin{array}{l}\text { Fluvial floodplains, colluvial and alluvial fans, slush- } \\
\text { flow fans, glacially scoured bedrock slopes, landslide } \\
\text { blocks, U-shaped valleys, thin glacial deposits over } \\
\text { bedrock, ice-rich creeping coarse colluvium, glacial } \\
\text { till and drift, fluvial terraces, fluvial meander belts, } \\
\text { eolian and lacustrine sands, lacustrine shorelines, } \\
\text { thermokarst badlands, parabolic sand dunes, } \\
\text { expanding kettle lakes, karst caves }\end{array}$ & $\begin{array}{l}\text { Deep-seated landsliding, slush flows, } \\
\text { snow and rock avalanches, rock fall, } \\
\text { stream icings, bimodal failures of sand } \\
\text { deposits, slumping of kettle lake mar- } \\
\text { gins, permafrost, torrential flooding }\end{array}$ \\
\hline $\begin{array}{l}\text { Atigun River } \\
\text { Gorge to Kuparuk River }\end{array}$ & $\begin{array}{l}\text { Lacustrine deposits, glacial moraines, glacial till, } \\
\text { kettle lakes, river channels, glacial erratics, thermo- } \\
\text { karst basins, eolian deposits }\end{array}$ & Solifluction, permafrost \\
\hline $\begin{array}{l}\text { Kuparuk River } \\
\text { to Happy Valley }\end{array}$ & $\begin{array}{l}\text { Glacial moraines, abandoned ice-marginal drainage } \\
\text { channels, ice-rich glacial drift, yedoma, glacial out- } \\
\text { wash fan, fluvial terraces and floodplains, frozen } \\
\text { upland deposits, horsetail drainage networks, kettle } \\
\text { lakes partially filled by solifluction colluvium, alluvial } \\
\text { fans, solifluction debris aprons }\end{array}$ & $\begin{array}{l}\text { Extensive stream icings, permafrost, } \\
\text { solifluction, bank erosion of yedoma } \\
\text { basins, bimodal failures }\end{array}$ \\
\hline $\begin{array}{l}\text { Happy Valley area to } \\
\text { Sagwon Bluffs area (TAPS } \\
\text { Pump Station 2) }\end{array}$ & $\begin{array}{l}\text { Colluvium- and glacial-till-covered upland surfaces, } \\
\text { braided fluvial floodplains, fluvial terraces, colluvial } \\
\text { and alluvial fans, solifluction fans }\end{array}$ & $\begin{array}{l}\text { Extensive stream icings, flooding, fluvial } \\
\text { erosion, flood surge flows on ice sheets, } \\
\text { floodplain expansion from bank erosion, } \\
\text { solifluction }\end{array}$ \\
\hline $\begin{array}{l}\text { Sagwon Bluffs (TAPS } \\
\text { Pump Station 2) to TAPS } \\
\text { Pump Station } 1\end{array}$ & $\begin{array}{l}\text { Fluvial floodplains and terraces, fan delta, ana- } \\
\text { branched and anastomosing fluvial channels, loess } \\
\text { deposits, irregular thaw lakes, string fens, polygonal } \\
\text { ground, sand dunes, frost scars, spot medallions, } \\
\text { beaded drainage patterns, closed-system pingos }\end{array}$ & $\begin{array}{l}\text { Extensive stream icings, flooding, con- } \\
\text { tinuous permafrost, thaw lake bank } \\
\text { erosion, drifting snow causing melting } \\
\text { permafrost }\end{array}$ \\
\hline
\end{tabular}




\section{REFERENCES}

Athey, J.E., Werdon, M.B., Newberry, R.J., Szumigala, D.J., Craw, P.A., and Hicks, S.A., 2004, Geologic maps of the Livengood SW C-3 and SE C-4 quadrangles, Tolovana mining district, Alaska: Alaska Division of Geological \& Geophysical Surveys Preliminary Interpretive Report 2004-3a, 1 sheet, scale 1:50,000. http://doi. org/10.14509/3309

Bemis, S.P., 2004, Neotectonic framework of the north-central Alaska Range foothills: Fairbanks, University of Alaska Fairbanks, M.S. thesis, 142 p.

2010, Moletrack scarps to mountainsQuaternary tectonics of the central Alaska Range: Eugene, OR, University of Oregon, Ph.D. dissertation, $121 \mathrm{p}$.

Bemis, S.P., Carver, G.A., and Koehler, R.D., 2012, The Quaternary thrust system of the northern Alaska Range: Geosphere, v. 8, no. 1, p. 196-205 http://doi.org/10.1130/GES00695.1

Bemis, S.P., and Wallace, W.K., 2007, Neotectonic framework of the north-central Alaska Range foothills, in Ridgway, K.D., Trop, J.M., Glen, J.M.G., and O'Neil, J.M., eds., Tectonic growth of a collisional continental margin-Crustal evolution of southern Alaska: Geological Society of America Special Paper 431, p. 549-572. http:// doi.org/10.1130/2007.2431(21)

Black, R.F., and Barksdale, W.L., 1949, Oriented lakes of northern Alaska: Journal of Geology, v. 57, no. 2, p. 105-118.

Briner, J.P., and Kaufman, D.S., 2008, Late Pleistocene mountain glaciation in Alaska-Key chronologies: Journal of Quaternary Science, v. 23, no. 6-7, p. 659-670.

Brown, Jerry, and Kreig, R.A., 1983, Guidebook to permafrost and related features along the Elliott and Dalton Highways, Fox to Prudhoe Bay, Alaska: Alaska Division of Geological \& Geophysical Surveys Guidebook 4, 230 p. http://doi. org/10.14509/266

Carson, C.E., and Hussey, K.M., 1962, The oriented lakes of arctic Alaska: Journal of Geology, v. 70, no. 4, p. 417-439. http://www.jstor.org/ stable/30063413

Carter, L.D., and Robinson, S.W., 1981, Minimum age of beach deposits north of Teshekpuk Lake, Alaskan Arctic Coastal Plain, in Albert, N.R.D., and Hudson, Travis, eds., The United States Geological Survey in Alaska; accomplishments during 1979: U.S. Geological Survey Circular 823-B, p. B8-B9. http://dggs.alaska.gov/pubs/ id/13428

Chapman, R.M., Yeend, Warren, Brosgé, W.P., and Reiser, H.N., 1982, Reconnaissance geologic map of the Tanana Quadrangle, Alaska: U.S. Geological Survey Open-File Report 82-734, 18 p., 1 sheet, scale 1:250,000. http://dggs.alaska. gov/pubs/id/11415

Daanen, R.P., Grosse, G., Darrow, M.M., Hamilton, T.D., and Jones, B.M., 2012, Rapid movement of frozen debris-lobes-Implications for permafrost degradation and slope instability in the south-central Brooks Range: Natural Hazards and Earth System Sciences, v. 12, no. 5, p. 1,521-1,537. http://doi.org/10.5194/ nhess-12-1521-2012

Darrow, M.M., Daanen, R.P., and Simpson, J.M., 2012, Monitoring and analysis of frozen debris lobes, phase I: Alaska Department of Transportation \& Public Facilities (FHWA-AK_ RD-12-17) and Alaska University Transportation Center (INE/AUTC 12.25) report, 63 p. http:// ine.uaf.edu/autc/files/2013/03/02-FDL-finaldraft.pdf

2013, Analysis of a Frozen Debris Lobe: A first look inside an impending geohazard, American Society of Civil Engineers, 10th International Symposium on Cold Regions Development, Anchorage, Alaska

Darrow, M. M., Gyswyt, N. L., Simpson, J. M., Daanen, R. P., and Hubbard, T. D., 2016, Frozen debris lobe morphology and movement: an overview of eight dynamic features, southern Brooks Range, Alaska, The Cryosphere, v. 10, p. 977-993. http://doi.org/10.5194/tc-10-977$\underline{2016}$

Detterman, R.L., Bowsher, A.L., and Dutro, J.T., Jr., 1958, Glaciation of the arctic slope of the Brooks Range, northern Alaska: Arctic, v. 11, no. 1, p. 43-61. http://pubs.aina.ucalgary.ca/arctic/ Arctic11-1-43.pdf 
Devore, J.R., Bemis, S.P., and Walker, L.A., 2012, Evidence for post-26ka displacement of the Northern Foothills thrust at the Nenana River, Alaska [abst.]: EOS Transactions, American Geophysical Union annual meeting, Abstract \#T11A-2552.

Dixon, E.J., Jr., 1975, The Gallagher Flint Station, an early man site on the North Slope, arctic Alaska, and its role in relation to the Bering Land Bridge: Arctic Anthropology, v. 7, p. 68-75. http://www.jstor.org/stable/40315863

Eberhart-Phillips, Donna, Haeussler, P.J., Freymueller, J.T., Frankel, A.D., Rubin, C.M., Craw, Patricia, Ratchkovski, N.A., Anderson, Greg, Carver, G.A., Crone, A.J., Dawson, T.E., Fletcher, Hilary, Hansen, Roger, Harp. E.L., Harris, R.A., Hill, D.P., Hreinsdottir, Sigrun, Jibson, R.W., Jones, L.M., Kayen, R.E., Keefer, D.K., Larsen, C.F., Moran, S.C., Personius, S.F., Plafker, George, Sherrod, B.L., Sieh, Kerry, Sitar, Nicholas, and Wallace, W.K., 2003, The 2002 Denali fault earthquake, Alaska-A large magnitude, slip-partitioned event: Science, v. 300, no. 5622, p. 1,113-1,118. http://doi. org/10.1126/science.1082703

Ferrians, O.J., Jr., Kachadoorian, Reuben, and Greene, G.W., 1969, Permafrost and related engineering problems in Alaska: U.S. Geological Survey Professional Paper 678, 37 p. http://dggs. alaska.gov/pubs/id/3938

Froese, D.G., Smith, D.G., Westgate, J.A., Ager, T.A., Preece, S.J., Sandhu, Amanjit, Enkin, R.J., and Weber, Florence, 2003, Recurring middle Pleistocene outburst floods in east-central Alaska: Quaternary Research, v. 60, no. 1, p. 50-62. http://doi.org/10.1016/S0033-5894(03)00090-5

Haeussler, P.J., Schwartz, D.P., Dawson, T.E., Stenner, H.D., Lienkaemper, J.J., Sherrod, B.L., Cinti, F.R., Montone, P., Craw, P.A., Crone, A.J., and Personius, S.F., 2004, Surface rupture and slip distribution of the Denali and Totschunda faults in the 3 November 2002 M7.9 earthquake, Alaska: Bulletin of the Seismological Society of America, v. 94, no. 6, Part B, p. 23-52.

Hamilton, T.D., 1978a, Surficial geologic map of the Chandalar Quadrangle, Alaska: U.S. Geological Survey Miscellaneous Field Studies Map
MF-878A, 1 sheet, scale 1:250,000. http://dggs. alaska.gov/pubs/id/13346

1978b, Surficial geologic map of the Philip Smith Mountains Quadrangle, Alaska: U.S. Geological Survey Miscellaneous Field Studies Map MF-879A, 1 sheet, scale 1:250,000. http:// dggs.alaska.gov/pubs/id/13355

1979, Surficial geologic map of the Wiseman Quadrangle, Alaska: U.S. Geological Survey Miscellaneous Field Studies Map MF-1122, 1 sheet, scale 1:250,000. http://dggs.alaska.gov/ pubs/id/13003

1982, A late Pleistocene glacial chronology for the southern Brooks Range-Stratigraphic record and regional significance: Geological Society of America Bulletin, v. 93, no. 8, p. 700-716. http://doi.org/10.1130/00167606(1982)93<700:ALPGCF>2.0.CO;2

1994, Late Cenozoic glaciation of Alaska, in Plafker, George, and Berg, H.C., eds., The geology of Alaska: Geological Society of America, Geology of North America, v. G-1, p. 813-844.

2002, Surficial geologic map of the Bettles Quadrangle, Alaska: U.S. Geological Survey Miscellaneous Field Studies Map MF-2409, version 1.0, 9 p., 1 sheet, scale 1:250,000. http:// pubs.usgs.gov/mf/2002/2409/

2003, Surficial geology of the Dalton Highway (Itkillik-Sagavanirktok Rivers) area, southern Arctic Foothills, Alaska: Alaska Division of Geological \& Geophysical Surveys Professional Report 121, 32 p., 1 sheet, scale 1:63,360. http:// doi.org/10.14509/7191

Harp, E.L., Jibson, R.W., Kayen, R.E., Keefer, D.K., Sherrod, B.L., Carver, G.A., Collins, B.A., Moss, R.E.S., and Sitar, Nicolas, 2003, Landslides and liquefaction triggered by the M 7.9 Denali Fault earthquake of 3 November 2002: GSA Today, v. 13, no. 8, p. 4-10. http://www.geosociety.org/gsatoday/archive/13/8/pdf/i1052-5173-13-8-4.pdf

Hubbard, T.D., 2016, Surficial-geologic map of parts of the Sagavanirktok and Toolik river drainages, northern Brooks Range foothills, Alaska: Alaska Division of Geological \& Geophysical Surveys Report of Investigation 2016-6, 1 sheet, scale 1:63,360. http://doi.org/10.14509/29472 
Hubbard, T.D., and Koehler, R.D., 2014, Geologic hazards investigations and mapping along proposed natural gas pipeline routes in Alaska [presentation]: Alaska Surveying \& Mapping Conference, 48th Annual Meeting, Fairbanks, Alaska, March 24-28, 2014.

Hubbard, T.D., Koehler, R.D., Combellick, R.A., 2011a, High-resolution lidar data for Alaska infrastructure corridors, Alaska Division of Geological and Geophysical Surveys, Raw-Data File 2011-3, 291 p. http://doi.org/10.14509/22722

Hubbard, T.D., Reger, R.D., Koehler, R.D., and Gallagher, P.E., 2011b, Using lidar to aid in evaluating geology and geologic hazards in the Alaska Highway Corridor [presentation]: Association of Environmental and Engineering Geologists Annual Meeting, Anchorage, Alaska, September 19-24, 2011. http://dggs.alaska.gov/ pubs/id/29322

Hubbard, T.D., Spangler, E.R., Daanen, R.P., Darrow, M.M., Simpson, J.M., and Southerland, L.E., 2013, Frozen debris lobes-Characterizing a potential geologic hazard along the Dalton Highway, southern Brooks Range, Alaska [poster]: Geological Society of America Annual Meeting, Denver, Colorado, October 27, 2013, Abstracts with Programs (49-15), v. 45, no. 7, p. 152: Alaska Division of Geological \& Geophysical Surveys, 1 sheet. http://doi. org/10.14509/29133

Jibson, R.W., Harp, E.L., Schulz, William, and Keefer, D.K., 2006, Large rock avalanches triggered by the M 7.9 Denali Fault Alaska earthquake of 3 November 2002: Engineering Geology, v. 83, p. 144-160.

Jorgenson, M. Torre, Yoshikawa, Kenji, Romanovsky, Vladamir, Kanevskiy, Mikhail, Brown, Jerry, Shur, Yuri, Marchenko, Sergei, Grosse, Guido, and Jones, Ben, 2008, Map of permafrost characteristics in Alaska, in Kane, D.L., and Hinkel, K.M., eds., Proceedings of the Ninth International Conference on Permafrost-Extended abstracts: Fairbanks, Alaska, University of Alaska Fairbanks, v. I, p. 121-122. www.uspermafrost. org/docs/proceedings-order-form.pdf
Kachadoorian, Reuben, 1960, Engineering and surficial geology of the Nenana-Rex area, Alaska: U.S. Geological Survey Miscellaneous Geologic Investigations Map I-307, 1 sheet, scale 1:63,360. http://dggs.alaska.gov/pubs/id/13601

Kanevskiy, M., Shur, Y., Connor, B., Dillon, M., Stephani, E., and O'Donnell, J., 2012, Study of ice-rich syngenetic permafrost for road design (Interior Alaska), in Hinkel, K.M., ed., Proceedings of the Tenth International Conference on Permafrost, Fairbanks, University of Alaska Fairbanks Institute of Northern Engineering, p. 191-196.

Kanevskiy, M., Shur, Y., Fortier, D., Jorgenson, M.T., and Stephani, E., 2011, Cryostratigraphy of late Pleistocene syngenetic permafrost (yedoma) in northern Alaska, Itkillik River exposure: Quaternary Research, v. 75, no. 3, p. 584-596. http://doi.org/10.1016/j.yqres.2010.12.003

Koehler, R.D., 2011, Application of lidar to mapping geologic hazards along gas pipelines in Alaska [abst.]: Geological Society of America, Cordilleran/Rocky Mountain Section, Abstracts with Programs, v. 43, no. 4, p. 83-84.

2013, Quaternary faults and folds (QFF): Alaska Division of Geological \& Geophysical Surveys Digital Data Series 3. http://maps.dggs. alaska.gov/qff/. http://doi.org/10.14509/24956

Koehler, R.D., and Reger, R.D., 2014, The Castle Mountain fault, south-central Alaska-Sense of slip and slip rate [invited presentation]: Seismological Research Letters, v. 85, no. 2, p. 475.

Koehler, R.D., Farrell, R.E., Burns, P.A.C., and Combellick, R.A., 2012a, Quaternary faults and folds in Alaska-A digital database, in Koehler, R.D., Quaternary faults and folds (QFF): Alaska Division of Geological \& Geophysical Surveys Miscellaneous Publication 141, 31 p., 1 sheet, scale 1:3,700,000. http://doi. org/10.14509/23944

Koehler, R.D., Reger, R.D., Carver, G.A., Spangler, E.R., and Gould, A.I., 2014, Castle Mountain fault, south-central Alaska-Observations on slip partitioning from lidar and paleoseismic trenching [abst.]: Geological Society of America Abstracts with Programs, v. 46, no. 6, p. 661, abstract \#247276. 
Koehler, R.D., Reger, R.D., and Frohman, R.A., 2012b, The Castle Mountain fault, south-central Alaska-New lidar-based observations on the sense of slip [abst.]: EOS Transactions, American Geophysical Union, Fall Meeting Supplement, Abstract \#S53D-2530.

Koehler, R.D., Reger, R.D., Sicard, K.R., and Spangler, E.R., 2013c, Yukon River landslide-Preliminary geologic and geotechnical evaluation: Alaska Division of Geological \& Geophysical Surveys Preliminary Interpretive Report 2013-6, 69 p. http://doi.org/10.14509/25642

Koehler, R.D., Reger, R.D., Spangler, E.R., and Gould, A.I., 2016, Investigation of potentially active tectonic faults along the route of the proposed Alaska Stand Alone Pipeline, Livengood to Cook Inlet, Alaska: Alaska Division of Geological \& Geophysical Surveys Report of Investigation 2015-4, 71 p. http://doi.org/10.14509/29409

Koehler, R.D., Reger, R.D., and Spangler, E., 2013b, A combined field and LiDAR mapping approach to characterizing geologic hazards-Natural gas pipeline corridor, Prudhoe Bay to Anchorage, Alaska [abst.]: Geological Society of America annual meeting, Abstracts with Programs, v. 45, no. 7, p. 719. https://gsa.confex.com/gsa/2013AM/ webprogram/Paper223858.html

Koehler, R.D., Schwarz, D.P., Rood, D.H., Reger, R.D., and Wolken, G.J., 2013a, Preliminary paleoseismic observations along the central Denali fault, Alaska [abst.]: EOS Transactions, American Geophysical Union, Fall Meeting Supplement, Abstract \#T23C-2598. http://doi. org/10.14509/26888

Kreig, R.A., and Reger, R.D., 1982, Air-photo analysis and summary of landform soil properties along the route of the Trans-Alaska Pipeline System: Alaska Division of Geological \& Geophysical Surveys Geologic Report 66, 149 p. http:// doi.org/10.14509/426

Mackay, J.R., 1979, Pingos of the Tuktoyaktuk Peninsula area, Northwest Territories: Revue de Géographie de Montreal, v. 33, no. 1, p. 3-61.

Mertie, J.B., Jr., 1937, The Yukon-Tanana region, Alaska: U.S. Geological Survey Bulletin 872, 276 p. http://dggs.alaska.gov/pubs/id/3453
Muhs, D.R., and Budahn, J.R., 2006, Geochemical evidence for the origin of late Quaternary loess in central Alaska: Canadian Journal of Earth Sciences, v. 43, no. 3, p. 323-337. http://doi. org/10.1139/E05-115

Mull, C.G., and Adams, K.E., eds., 1989, Bedrock geology of the eastern Koyukuk basin, central Brooks Range, and east-central Arctic Slope along the Dalton Highway, Yukon River to Prudhoe Bay, Alaska, Volume 1: Alaska Division of Geological \& Geophysical Surveys Guidebook 7, vol. 1, 309 p., 1 sheet, scale $1 "=45 \mathrm{mi}$. http:// doi.org/10.14509/269

Page, R.A., Plafker, George, and Pulpan, Hans, 1995, Block rotation in east-central Alaska-A framework for evaluating earthquake potential?: Geology, v. 23, no. 7, p. 629-632. http://doi. org/10.1130/0091-7613(1995)023<0629:BRIE $\mathrm{CA}>2.3 . \mathrm{CO} ; 2$

Patton, W.W., and Miller, T., 1973, Bedrock geologic map of Bettles and southern part of Wiseman quadrangles, Alaska: U.S. Geological Survey Miscellaneous Field Investigations Map MF-492, 1 sheet, scale 1:250,000. http://dggs. alaska.gov/pubs/id/12866

Péwé, T.L., 1949, Preliminary report on permafrost investigations in the Dunbar area, Alaska: U.S. Geological Survey Circular 49, 3 p.

1954, Effect of permafrost on cultivated fields, Fairbanks, Alaska: U.S. Geological Survey Bulletin 989-F, p. F315-F351.

Péwé, T.L., Wahrhaftig, Clyde, and Weber, F.R., 1966, Geologic map of the Fairbanks Quadrangle, Alaska: U.S. Geological Survey Miscellaneous Geologic Investigations Map I-455, 5 p., 1 sheet, scale 1:250,000.

Plafker, George, Moore, J.C., and Winkler, G.R., 1994, Geology of the southern Alaska margin, in Plafker, George, and Berg, H.C., eds., The Geology of Alaska: Geological Society of America, p. 389-448. http://dggs.alaska.gov/pubs/id/22292

Post, Austin, and Mayo, L.R., 1971, Glacier dammed lakes and outburst floods in Alaska: U.S. Geological Survey Hydrologic Atlas HA455, 10 p., 3 sheets, scale 1:1,000,000. 
Rawlinson, S.E., 1983, Guidebook to permafrost and related features at Prudhoe Bay: Alaska Division of Geological \& Geophysical Surveys Guidebook 5, 150 p. http://doi. org/10.14509/267

1987, Preliminary photointerpretive maps of the geology, geologic materials, permafrost, and wetlands classification of the Fairbanks B-5 Quadrangle, Alaska, 1987: Alaska Division of Geological \& Geophysical Surveys Public Data File 87-17, 25 p., 4 sheets, scale 1:31,680. http://doi.org/10.14509/1319

Reger, R.D., 1978, Reconnaissance geology of the Talkeetna-Kashwitna area, Susitna River basin, Alaska: Alaska Division of Geological \& Geophysical Surveys Alaska Open-File Report 107A, 1 sheet, scale 1:63,360. http://doi. org/10.14509/12

1987, Preliminary photointerpretive maps of the geology, geologic materials, permafrost, and wetlands classification, Fairbanks C-5 Quadrangle, Alaska: Alaska Division of Geological \& Geophysical Surveys Public Data File 87-19, 22 p., 4 sheets, scale 1:31,680. http://doi.org/10.14509/1321

Reger, R.D., Combellick, R.A., and BrighamGrette, Julie, 1995, Late-Wisconsin events in the upper Cook Inlet region, southcentral Alaska, in Combellick, R.A., and Tannian, Fran, eds., Short Notes on Alaska Geology 1995: Alaska Division of Geological \& Geophysical Surveys Professional Report 117D, p. 33-45. http://doi.org/10.14509/2320

Reger, R.D., Combellick, R.A., and Pinney, D.S., 1994, Geologic and derivative materials maps of the Anchorage C-8 NE Quadrangle, Alaska: Alaska Division of Geological \& Geophysical Surveys Report of Investigation 94-26, 2 sheets, scale 1:25,000. http://doi. org/10.14509/2509

Reger, R.D., Hubbard, T.D., and Koehler, R.D., in press, Surficial geology and geohazards in the Alaska Highway corridor, Alaska: Alaska Division of Geological \& Geophysical Surveys Report of Investigation 2016-X, booklet, 18 sheets, scale 1:63,360.
Reger, R.D., Sturrmann, A.G., Berg,. E.E., and Burns, P.A.C., 2007, A guide to the late Quaternary history of northern and western Kenai Peninsula, Alaska: Alaska Division of Geological \& Geophysical Surveys Guidebook 8, 112 p., 6 sheets, scale 1:63,360.

Reger, R.D., and Updike, R.G., 1983, Upper Cook Inlet and the Matanuska Valley, in Péwé, T.L., and Reger, R.D., eds., Guidebook to permafrost and Quaternary geology along the Richardson and Glenn Highways between Fairbanks and Anchorage, Alaska: Alaska Division of Geological \& Geophysical Surveys Guidebook 1, p. 185-263, 1 sheet, scale 1:250,000. http://doi.org/10.14509/263

Schwartz, D.P., Dawson, T.E., Haeussler, P.J., Lienkaemper, J.J., Matmon, A., Stenner, H.D., Sherrod, B., Cinti, F.R., Montone, P., Carver, G.A., and Plafker, George, 2003, Paleoearthquakes on the Denali-Totschunda fault system-Preliminary observations of slip and timing [abst.]: American Geophysical Union, fall meeting, abstract \#S11B-03.

Scott, K.M., 1978, Effect of permafrost on stream channel behavior in arctic Alaska: U.S. Geological Survey Professional Paper 1068, 19 p. http://dggs.alaska.gov/pubs/id/3974

Sellmann, P.V., Brown, Jerry, Lewellen, R.I., McKim, H.L., and Merry, C.J., 1975, The classification and geomorphic implications of thaw lakes on the Arctic Coastal Plain, Alaska: U.S. Army Material Command Cold Regions Research and Engineering Laboratory Research Report 344, 21 p.

Shur, Yuri, Kanevskiy, Mikhail, Dillon, Matthew, Stephani, Eva, and O'Connell, Jonathan, 2010, Geotechnical investigations for the Dalton Highway innovation project as a case study of the ice-rich syngenetic permafrost: Alaska Department of Transportation \& Public Facilities Report FHWA-AK-RD-10-06, 160 p.

Simpson, J.M., Darrow, M.M, Huang, S.L., Daanen, R.P., and Hubbard, T.D., 2016, Investigating movement and characteristics of a frozen debris lobe, South-central Brooks Range, Alaska, Environmental \& Engineering 
Geoscience, v. 22, n. 3, p. 259-277. https:// doi.org/10.2113/gseegeosci.22.3.259

Sloan, C.E., Zenone, Chester, and Mayo, L.R., 1976, Icings along the Trans-Alaska Pipeline route: U.S. Geological Survey Professional Paper 979, $31 \mathrm{p}$.

Solie, D.N., and Athey, J.E., 2015, Preliminary evaluation of bedrock potential for naturally occurring asbestos in Alaska: Alaska Division of Geological \& Geophysical Surveys Miscellaneous Publication 157, 15 p., 21 sheets, scale 1:500,000. http://doi.org/10.14509/29447

Spangler, E.R., and Hubbard, T.D., in press, Geologic and geomorphic mapping of frozen debris lobe source basins along the Dalton Highway, southern Brooks Range, Alaska: Alaska Division of Geological \& Geophysical Surveys Report of Investigation 2016-X, 42 p.

Spangler, E.R., Hubbard, T.D., Daanen, R.P., Darrow, M.M., Simpson, J.M., and Southerland, L.E., 2013, Geologic and geomorphic characterization of frozen debris lobe catchments along the Dalton Highway, southern Brooks Range, Alaska [poster]: Geological Society of America Annual Meeting, Denver, Colorado, October 27, 2013, Abstracts with Programs (49-16), v. 45, no. 7, p. 152: Alaska Division of Geological \& Geophysical Surveys, 1 sheet. http://doi. org/10.14509/27007

Tape, Carl, Silwal, Vipul, Chen, Junming, Keyson, L., West, Michael, and Ruppert, N.A., 2015, Transtensional tectonics of the Minto Flats fault zone and Nenana basin, central Alaska: Bulletin of the Seismological Society of America, v. 105, no. 4, p. 2,081-2,100.

Ten Brink, N.W., and Waythomas, C.F., 1985, Late Wisconsin glacial chronology of the north-central Alaska Range; a regional synthesis and its implications for early human settlements, in Powers, W.R., and others, eds., North Alaska Range Early Man Project: National Geographic Society Reports, v. 19, p. 15-32.

Thorson, R.M., 1986, Late Cenozoic glaciation of the northern Nenana Valley, in Hamilton, T.D., Reed, K.M., and Thorson, R.M., eds., Glaciation in Alaska, the geologic record: Anchorage,
Alaska Geological Society, p. 99-121.

1989, Late Quaternary paleofloods along the Porcupine River, Alaska-Implications for regional correlation, in Carter, L.D., Hamilton, T.D., and Galloway, J.P., eds., Late Cenozoic history of the interior basins of Alaska and the Yukon: U.S. Geological Survey Circular 1026, p. 51-54. http://dggs.alaska.gov/pubs/id/13412

Thorson, R.M., and Dixon, E.J., Jr., 1983, Alluvial history of the Porcupine River, Alaska-Role of glacial-lake overflow from Northwest Canada: Geological Society of America Bulletin, v. 94, no.

5, p. 576-589. http://doi.org/10.1130/00167606(1983)94<576:AHOTPR>2.0.CO;2

Twelker, Evan, Athey, J.E., Newberry, R.J., Griesel, G.A., Szumigala, D.J., Freeman, L.K., Elliott, B.A., Werdon, M.B., and Stevens, D.S.P., 2016, Geologic map of portions of the Livengood B-3, B-4, C-3, and C-4 quadrangles, Tolovana mining district, Alaska: Alaska Division of Geological \& Geophysical Surveys Report of Investigation 2016-5, 39 p., 1 sheet, scale 1:50,000. http://doi. org/10.14509/29665

Ulery, C.A., and Updike, R.G., 1983, Subsurface structure of the cohesive facies of the Bootlegger Cove Formation, southwest Anchorage: Alaska Division of Geological \& Geophysical Surveys Professional Report 84, 5 p., 3 sheets, scale 1:15,840. http://doi.org/10.14509/2257

Updike, R.G., and Howland, M.D., 1979, Surficial geology and processes, Prudhoe Bay oil field, with hydrologic implications: Alaska Division of Geological \& Geophysical Surveys Special Report 16, 6 p., 17 sheets, scale 1:12,000. http:// doi.org/10.14509/2615

Wahrhaftig, Clyde, 1958, Quaternary geology of the Nenana River valley and adjacent parts of the Alaska Range, in Wahrhaftig, Clyde, and Black, R.F., Quaternary and engineering geology in the central part of the Alaska Range: U.S. Geological Survey Professional Paper 293, p. 1-68. http:// dggs.alaska.gov/pubs/id/3821

1965, Physiographic divisions of Alaska: U.S. Geological Survey Professional Paper 482, 52 p., 6 sheets, various scales. http://dggs.alaska. gov/pubs/id/3872 
1968, Schists of the central Alaska Range: U.S. Geological Survey Bulletin 1254-E, p. E1E22. http://dggs.alaska.gov/pubs/id/3654 1970a, Geologic map of the Healy D-4 Quadrangle, Alaska: U.S. Geological Survey Geologic Quadrangle Map GQ-806, 1 sheet, scale 1:63,360. http://dggs.alaska.gov/pubs/ id/12899

1970b, Geologic map of the Healy D-5 Quadrangle, Alaska: U.S. Geological Survey Geologic Quadrangle Map GQ-807, 1 sheet, scale 1:63,360. http://dggs.alaska.gov/pubs/ id/12900

1970c, Geologic map of the Fairbanks A-5 Quadrangle, Alaska: U.S. Geological Survey Geologic Quadrangle Map GQ-811, 1 sheet, scale 1:63,360. http://dggs.alaska.gov/pubs/ id/12896

1987, The Cenozoic section at Suntrana, Alaska, in Hill, M.L., ed., Centennial Field Guide 1, Cordilleran Section: Geological Society of America DNAG Cordilleran Section Centennial Field Guide 1, p. 445-450.

Wahrhaftig, Clyde, and Black, R.F., 1958, Engineering geology along part of the Alaska Railroad, in Wahrhaftig, Clyde, and Black, R.F., Quaternary and engineering geology in the central part of the Alaska Range: U.S. Geological Survey Professional Paper 293B, p. 69-118. http://dggs. alaska.gov/pubs/id/3821

Wahrhaftig, Clyde, Wolfe, J.A., Leopold, E.B., and Lanphere, M.A., 1969, The coal-bearing group in the Nenana coal field, Alaska: U.S. Geological Survey Bulletin 1274-D, p. D1-D30. http:// dggs.alaska.gov/pubs/id/3660

Walker, D.A., Walker, M.D., Everett, K.R., and Webber, P.J., 1985, Pingos of the Prudhoe Bay region, Alaska: Arctic and Alpine Research, v. 17, no. 3, p. 321-336. http://doi. org/10.2307/1551021

Waythomas, C.F., TenBrink, N.W., and Ritter, D.F., 1984, Surficial geology of the Livengood B-3, B-4, C-3, and C-4 quadrangles, Yukon-Tanana Upland, Alaska: Alaska Division of Geological \& Geophysical Surveys Report of Investigation 84-6, 1 sheet, scale 1:63,360. http://doi. org/10.14509/2365

Weber, F.R., Wheeler, K.L., Rinehart, C.D., Chapman, R.M., and Blodgett, R.B., 1992, Geologic map of the Livengood Quadrangle, Alaska: U.S. Geological Survey Open-File Report 92-562, 20 p., 1 sheet, scale 1:250,000.

Weber, F.R., Wheeler, K.L., Rinehart, C.D., and Light, T.D., 1997, Generalized geologic map of the Livengood Quadrangle, Alaska: U.S. Geological Survey Open-File Report 97-484-A, 1 sheet, scale 1:250,000. http://dggs.alaska.gov/ pubs/id/12827

Williams, J.R., 1962, Geologic reconnaissance of the Yukon Flats district, Alaska: U.S. Geological Survey Bulletin 1111-H, p. 289-331, 1 sheet, scale 1:500,000. http://dggs.alaska.gov/pubs/ $\underline{\mathrm{id} / 3617}$ 


\section{APPENDIX A. MAP SYMBOLS FOR OBSERVATION POINTS ALONG THE PARKS HIGHWAY, MINTO FLATS, AND DALTON HIGHWAY INFRASTRUCTURE CORRIDORS}

\begin{tabular}{|c|c|c|c|}
\hline Symbol & Definition & $\begin{array}{l}\text { Map } \\
\text { Sheet }\end{array}$ & Lat/Long ${ }^{1}$ \\
\hline 2 & $\begin{array}{l}\text { Terminal moraine of Knik lobe of Elmendorf stadial advance } \\
\text { (Reger and Updike, 1983; Reger and others, 1995), }\end{array}$ & $\begin{array}{l}\text { sheet } 1 \\
\text { map } 1\end{array}$ & $61.4579,-150.1177$ \\
\hline 3 & South-facing fold scarp along Castle Mountain fault & $\begin{array}{l}\text { sheet } 1 \\
\text { map } 1\end{array}$ & $61.5418,-150.2306$ \\
\hline $3 a$ & Strand of Denali fault & $\begin{array}{l}\text { sheet 2, } \\
\text { map } 4\end{array}$ & $\begin{array}{l}63.4512,-148.8655 \text { and } \\
63.4521,-148.8725\end{array}$ \\
\hline $3 b$ & Possible older fault strand & $\begin{array}{l}\text { sheet } 2 \text {, } \\
\text { map } 4\end{array}$ & $63.4456,-148.9813$ \\
\hline 4 & $\begin{array}{l}\text { Sand dune field on terminal moraine of Elmendorf glacial } \\
\text { advance ( 13-14 RC Ka) (Reger and Updike, 1983; Reger } \\
\text { and others, 1995) }\end{array}$ & $\begin{array}{l}\text { sheet } 1 \\
\text { map } 1\end{array}$ & $61.5658,-150.1844$ \\
\hline $4 a$ & $\begin{array}{l}\text { Terminal moraine of Elmendorf glacial advance ( 13-14 RC } \\
\text { Ka) with sand dune cover }\end{array}$ & $\begin{array}{l}\text { sheet } 1 \\
\text { map } 1\end{array}$ & $61.6446,-150.1973$ \\
\hline 12 & Low fluvial terrace along the Little Susitna River & $\begin{array}{l}\text { sheet } 1 \\
\text { map } 1\end{array}$ & $61.5757,-150.0524$ \\
\hline 13 & $\begin{array}{l}\text { Extensive Holocene sand-dune complex and sandy } \\
\text { braidplain of late Naptowne glacioestuarine transgression } \\
\text { (Reger and Updike, 1983; Reger and others, 1995) }\end{array}$ & $\begin{array}{l}\text { sheet 1, } \\
\text { map } 1\end{array}$ & $61.5405,-150.2648$ \\
\hline 20 & $\begin{array}{l}\text { Wave-cut scarp; a radiocarbon date of } 10,720 \pm 460 \text { years } \\
\text { BP (GX-6041) for peat at the base of this wave-cut scarp is a } \\
\text { minimum age for the invasion of the Susitna River lowland } \\
\text { by glacioestuarine waters during the Elmendorf stade of } \\
\text { the Naptowne glaciation (Reger and Updike, 1983) }\end{array}$ & $\begin{array}{l}\text { sheet } 1 \\
\text { map } 1\end{array}$ & $61.6085,-150.2356$ \\
\hline 21 & $\begin{array}{l}\text { Broad, sandy braidplain underlain by Bootlegger Cove For- } \\
\text { mation (Reger and Updike, 1983; Reger and others, 1995) }\end{array}$ & $\begin{array}{l}\text { sheet 1, } \\
\text { map } 1\end{array}$ & $61.6078,-150.2469$ \\
\hline 23 & Broad, sandy braidplain (Reger and Updike, 1983, plate 1) & $\begin{array}{l}\text { sheet } 1 \\
\text { map } 1\end{array}$ & $61.7139,-150.1810$ \\
\hline 24 & Pitted proximal outwash of Elmendorf stade (GFop) & $\begin{array}{l}\text { sheet } 1 \text {, } \\
\text { map } 1\end{array}$ & $61.7402,-150.1411$ \\
\hline 25 & Large, active gravel pit & $\begin{array}{l}\text { sheet } 1 \\
\text { map } 1\end{array}$ & $61.8576,-150.0780$ \\
\hline 26 & Sheep Creek slough, shallow ground water & $\begin{array}{l}\text { sheet } 1 \\
\text { map } 2\end{array}$ & $62.0176,-150.0835$ \\
\hline 28 & Susitna River braided floodplain & $\begin{array}{l}\text { sheet } 1 \text {, } \\
\text { map } 2\end{array}$ & $62.1778,-150.1436$ \\
\hline 29 & Fluted ground moraine (lodgement till) & $\begin{array}{l}\text { sheet } 1 \text {, } \\
\text { map } 2\end{array}$ & $\begin{array}{l}62.2755,-150.2602 ; \\
62.2858,-150.2623 ; \text { and } \\
62.2972,-150.2590\end{array}$ \\
\hline \multicolumn{2}{|c|}{ 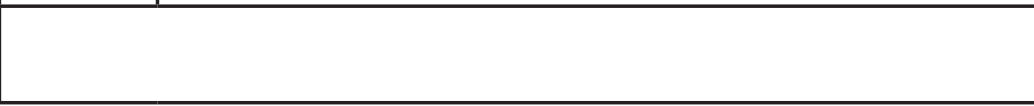 } & $\begin{array}{l}\text { sheet } 1 \text {, } \\
\text { map } 3\end{array}$ & $62.9800,-149.6445$ \\
\hline
\end{tabular}




\begin{tabular}{|c|c|c|c|}
\hline Symbol & Definition & $\begin{array}{l}\text { Map } \\
\text { Sheet }\end{array}$ & Lat/Long ${ }^{1}$ \\
\hline 30 & $\begin{array}{l}\text { Eolian cover sands over outwash of Elmendorf age (Es/ } \\
\text { GFo) }\end{array}$ & $\begin{array}{l}\text { sheet } 1 \text {, } \\
\text { map } 2\end{array}$ & $\begin{array}{l}62.3052,-150.2449 \text { and } \\
62.3193,-150.2465\end{array}$ \\
\hline 31 & Elmendorf terminal moraine; 13-14 RC ka & $\begin{array}{l}\text { sheet 1, } \\
\text { map 2 }\end{array}$ & $62.3231,-150.2520$ \\
\hline 32 & Subtle scarp, probably temporary glacial limit & $\begin{array}{l}\text { sheet } 1 \text {, } \\
\text { map } 2\end{array}$ & $62.4272,-150.2828$ \\
\hline 33 & End moraine? & $\begin{array}{l}\text { sheet } 1 \text {, } \\
\text { map } 2\end{array}$ & $\begin{array}{l}62.5416,-150.2527 \text { and } \\
62.7277,-150.1646\end{array}$ \\
\hline 36 & Tunnel channel cut by subglacial flooding & $\begin{array}{l}\text { sheet 1, } \\
\text { map 2 }\end{array}$ & $62.6798,-150.2495$ \\
\hline 40 & Kettles (pitted Fac) & $\begin{array}{l}\text { sheet } 1 \text {, } \\
\text { map } 2\end{array}$ & $\begin{array}{l}62.7343,-150.1362 ; \\
62.7365,-150.1329 ; \text { and } \\
62.7371,-150.1336\end{array}$ \\
\hline 41 & Possible recessional moraine & $\begin{array}{l}\text { sheet } 1 \text {, } \\
\text { map 2 }\end{array}$ & $62.7430,-150.1486$ \\
\hline 42 & $\begin{array}{l}\text { Zone of widespread seasonal stream icings on braided } \\
\text { floodplain }\end{array}$ & $\begin{array}{l}\text { sheet 1, } \\
\text { map 2 }\end{array}$ & $62.7567,-150.1330$ \\
\hline 43 & Subtle landslide in thick till & $\begin{array}{l}\text { sheet } 1 \text {, } \\
\text { map } 2\end{array}$ & $62.7595,-150.0813$ \\
\hline 44 & Recessional moraine upland complex & $\begin{array}{l}\text { sheet } 1 \text {, } \\
\text { map } 3\end{array}$ & $\begin{array}{l}62.7878,-150.0390 \text { and } \\
62.7919,-149.9916\end{array}$ \\
\hline 46 & Partially eroded landslide in thick till & $\begin{array}{l}\text { sheet } 1 \text {, } \\
\text { map } 3\end{array}$ & $62.8205,-149.9501$ \\
\hline 47 & $\begin{array}{l}\text { Byers Creek occupies a deep former meltwater channel } \\
\text { into which the Chulitna River was diverted by a thickening } \\
\text { and expanding Eldridge Glacier late in the Elmendorf stade } \\
\text { (stage 2) }\end{array}$ & $\begin{array}{l}\text { sheet } 1 \text {, } \\
\text { map } 3\end{array}$ & $62.8166,-149.9075$ \\
\hline 50 & Flood scoured scarp cut by glacially diverted Chulitna River & $\begin{array}{l}\text { sheet } 1 \text {, } \\
\text { map } 3\end{array}$ & $62.8661,-149.8416$ \\
\hline 51 & Outwash terraces & $\begin{array}{l}\text { sheet } 1 \text {, } \\
\text { map } 3\end{array}$ & $62.8839,-149.7967$ \\
\hline 52 & $\begin{array}{l}\text { Structure of Tertiary bedrock exposed through thin, braided } \\
\text { stream alluvium, }\end{array}$ & $\begin{array}{l}\text { sheet } 1 \text {, } \\
\text { map } 3\end{array}$ & $62.8950,-149.7804$ \\
\hline 53 & Abandoned meltwater channel (floodway) & $\begin{array}{l}\text { sheet } 1 \text {, } \\
\text { map } 3\end{array}$ & $62.9001,-149.7214$ \\
\hline 54 & $\begin{array}{l}\text { Colluvial-alluvial fan that postdates diversion of the } \\
\text { Chulitna River into the Byer Lake channel }\end{array}$ & $\begin{array}{l}\text { sheet } 1 \text {, } \\
\text { map } 3\end{array}$ & $62.9051,-149.7058$ \\
\hline 55 & Re-scoured bedrock (possibly flood scoured) & $\begin{array}{l}\text { sheet } 1 \text {, } \\
\text { map } 3\end{array}$ & $62.9092,-149.7010$ \\
\hline 56 & Kettle holes & $\begin{array}{l}\text { sheet } 1 \text {, } \\
\text { map } 3\end{array}$ & $62.9129,-149.7101$ \\
\hline 57 & Braided outwash alluvium & $\begin{array}{l}\text { sheet } 1 \text {, } \\
\text { map } 3\end{array}$ & $62.9153,-149.7227$ \\
\hline 66 & Gravel pit & $\begin{array}{l}\text { sheet } 1 \text {, } \\
\text { map } 3\end{array}$ & $63.1213,-149.4603$ \\
\hline
\end{tabular}




\begin{tabular}{|c|c|c|c|}
\hline Symbol & Definition & $\begin{array}{l}\text { Map } \\
\text { Sheet }\end{array}$ & Lat/Long ${ }^{1}$ \\
\hline 68 & $\begin{array}{l}\text { Sideslope blankets of till creeping and flowing toward bot- } \\
\text { toms of grooves by gelifluction }\end{array}$ & $\begin{array}{l}\text { sheet } 1 \text {, } \\
\text { map } 3\end{array}$ & $\begin{array}{l}63.3084,-149.1896 \text { and } \\
63.3648,-148.9986\end{array}$ \\
\hline 70 & $\begin{array}{l}\text { Ridges of thin till streamlined by southeastward flow of } \\
\text { stage } 2 \text { glacier through Broad Pass prior to } \sim 9,300 \text { RC yr } \\
\text { B.P., }\end{array}$ & $\begin{array}{l}\text { sheet } 1 \text {, } \\
\text { map } 3\end{array}$ & $63.3447,-149.0523$ \\
\hline 72 & $\begin{array}{l}\text { Radiocarbon age of basal frozen peat on stage } 2 \text { till 9,300 } \\
\text { RC yr B.P }\end{array}$ & $\begin{array}{l}\text { sheet } 1 \text {, } \\
\text { map } 3\end{array}$ & $63.3680,-148.9902$ \\
\hline 75 & Denali fault & $\begin{array}{l}\text { sheet 2, } \\
\text { map } 4\end{array}$ & $63.4571,-148.7291$ \\
\hline 77 & Sackung in bedrock & $\begin{array}{l}\text { sheet 2, } \\
\text { map } 4\end{array}$ & $63.4735,-148.7315$ \\
\hline 80 & Colluvial fan with steep margins & $\begin{array}{l}\text { sheet } 1 \text {, } \\
\text { map } 3\end{array}$ & $63.4205,-149.1237$ \\
\hline 81 & Panorama Mountain rock avalanche & $\begin{array}{l}\text { sheet } 2 \text {, } \\
\text { map } 4\end{array}$ & $\begin{array}{l}63.4905,-148.8331 \text { and } \\
63.4980,-148.8320\end{array}$ \\
\hline $81 a$ & Flood-scoured Panorama Mountain rock avalanche & $\begin{array}{l}\text { sheet } 2, \\
\text { map } 4\end{array}$ & $63.4986,-148.8223$ \\
\hline $81 b$ & $\begin{array}{l}\text { Penultimate Panorama Mountain rock avalanche, probably } \\
\text { deposited on glacial ice during Carlo advance }\end{array}$ & $\begin{array}{l}\text { sheet 2, } \\
\text { map } 4\end{array}$ & $63.5086,-148.8270$ \\
\hline 82 & Carlo glacial limit & $\begin{array}{l}\text { sheet 2, } \\
\text { map } 4\end{array}$ & $63.5627,-148.8007$ \\
\hline 83 & Carlo terminal moraine (Warhaftig, 1958) & $\begin{array}{l}\text { sheet } 2 \text {, } \\
\text { map } 4\end{array}$ & $63.5925,-148.7976$ \\
\hline 84 & Late Riley Creek lateral moraine & $\begin{array}{l}\text { sheet } 2 \text {, } \\
\text { map } 4\end{array}$ & $63.6060,-148.7581$ \\
\hline $84 a$ & $\begin{array}{l}\text { Riley Creek recessional moraine modified by waves in melt- } \\
\text { water lake of late Riley Creek age }\end{array}$ & $\begin{array}{l}\text { sheet 2, } \\
\text { map } 4\end{array}$ & $63.6666,-148.7621$ \\
\hline 85 & Carlo glacial outwash & $\begin{array}{l}\text { sheet } 2 \text {, } \\
\text { map } 4\end{array}$ & $\begin{array}{l}63.6169,-148.7651 ; \\
63.8602,-149.0062 ; \text { and } \\
63.9875,-149.1210\end{array}$ \\
\hline 86 & Late Riley Creek end moraine (stage 2) & $\begin{array}{l}\text { sheet 2, } \\
\text { map } 4\end{array}$ & $63.6359,-148.7341$ \\
\hline 87 & $\begin{array}{l}\text { Yanert Fork of Nenana River, subject to outburst flooding } \\
\text { (Post and Mayo, 1971) }\end{array}$ & $\begin{array}{l}\text { sheet 2, } \\
\text { map } 4\end{array}$ & $63.6808,-148.7629$ \\
\hline 91 & Riley Creek terminal moraine & $\begin{array}{l}\text { sheet } 2, \\
\text { map } 4\end{array}$ & $\begin{array}{l}63.7162,-148.8295 \text { and } \\
63.7199,-148.9020\end{array}$ \\
\hline 92 & Fault scarp, Park Road fault & $\begin{array}{l}\text { sheet } 2 \text {, } \\
\text { map } 4\end{array}$ & $63.7242,-148.9061$ \\
\hline 93 & $\begin{array}{l}\text { Pre-Riley Creek lateral moraine deposited by ice flowing } \\
\text { westward from Nenana River valley }\end{array}$ & $\begin{array}{l}\text { sheet 2, } \\
\text { map } 4\end{array}$ & $63.7155,-149.1145$ \\
\hline $100 a$ & Eroded remnant of Healy terminal moraine & $\begin{array}{l}\text { sheet 2, } \\
\text { map } 4\end{array}$ & $63.8875,-149.0492$ \\
\hline 102 & Possible Park Road fault & $\begin{array}{l}\text { sheet 2, } \\
\text { map } 4\end{array}$ & $63.7244,-148.9855$ \\
\hline
\end{tabular}




\begin{tabular}{|c|c|c|c|}
\hline Symbol & Definition & $\begin{array}{l}\text { Map } \\
\text { Sheet }\end{array}$ & Lat/Long ${ }^{1}$ \\
\hline 104 & Healy moraine & $\begin{array}{l}\text { sheet 2, } \\
\text { map } 4\end{array}$ & $63.7305,-148.9522$ \\
\hline $104 a$ & Healy terminal moraine & $\begin{array}{l}\text { sheet 2, } \\
\text { map } 4\end{array}$ & $63.8473,-149.0242$ \\
\hline 105 & Riley Creek outwash & $\begin{array}{l}\text { sheet } 2 \text {, } \\
\text { map } 4\end{array}$ & $\begin{array}{l}63.7357,-148.9051 ; \\
63.9300,-149.0876 ; \text { and } \\
64.1414,-149.2650\end{array}$ \\
\hline 106 & Diversion channels & $\begin{array}{l}\text { map 2, } \\
\text { sheet } 4\end{array}$ & $63.7978,-148.9279$ \\
\hline 107 & $\begin{array}{l}\text { Landslide in glacial lake sediments along Alaska Railroad } \\
\text { (Wahrhaftig and Black, 1958) }\end{array}$ & $\begin{array}{l}\text { map 2, } \\
\text { sheet } 4\end{array}$ & $63.7982,-148.9399$ \\
\hline 108 & Thin Riley Creek outwash & $\begin{array}{l}\text { sheet 2, } \\
\text { map } 4\end{array}$ & $\begin{array}{l}63.8608,-149.0237 ; \\
63.9585,-149.1062 ; \\
63.9781,-149.1146 ; \\
64.0599,-149.1804 ; \\
64.0852,-149.2023 ; \\
64.1030,-149.2246 ; \text { and } \\
64.1949,-149.2954\end{array}$ \\
\hline 110 & $\begin{array}{l}\text { Healy outwash (stage 4) (Wahrhaftig, 1970b; Kachadoorian, } \\
\text { 1960) }\end{array}$ & $\begin{array}{l}\text { sheet 2, } \\
\text { map } 4\end{array}$ & $\begin{array}{l}63.9037,-149.0776 \\
64.0605,-149.1979 ; \\
64.1046,-149.2442 ; \text { and } \\
64.2778,-149.1183\end{array}$ \\
\hline 111 & Healy outwash (Wahrhaftig, 1970b) & $\begin{array}{l}\text { sheet } 2 \text {, } \\
\text { map } 4\end{array}$ & $\begin{array}{l}63.9226,-149.0968 ; \\
63.9219,-149.1037 ; \text { and } \\
64.2177,-149.2546\end{array}$ \\
\hline 112 & Dissected Healy outwash & $\begin{array}{l}\text { sheet 2, } \\
\text { map } 4\end{array}$ & $63.9526,-149.1223$ \\
\hline 113 & $\begin{array}{l}\text { Landslide in Tertiary bedrock and metamorphic slate and } \\
\text { schist (Waythomas and others, 1984) }\end{array}$ & $\begin{array}{l}\text { sheet 2, } \\
\text { map } 4\end{array}$ & $63.9798,-149.1361$ \\
\hline 115 & Mixed outwash and fluvial gravel & $\begin{array}{l}\text { sheet 2, } \\
\text { map } 4\end{array}$ & $64.0156,-149.1377$ \\
\hline 116 & Healy alluvium (stage 4) & $\begin{array}{l}\text { sheet 2, } \\
\text { map } 4\end{array}$ & $64.0363,-149.1698$ \\
\hline 117 & Riley Creek alluvial terrace & $\begin{array}{l}\text { sheet 2, } \\
\text { map } 4\end{array}$ & $64.1480,-149.2870$ \\
\hline 118 & Fan deposits over Healy alluvium & $\begin{array}{l}\text { sheet } 2 \text {, } \\
\text { map } 4\end{array}$ & $64.1613,-149.2931$ \\
\hline 119 & Granitic erratics of Browne glaciation & $\begin{array}{l}\text { sheet 2, } \\
\text { map } 4\end{array}$ & $64.1674,-149.3041$ \\
\hline 120 & Riley Creek outwash (Wahrhaftig, 1970c) & $\begin{array}{l}\text { sheet 2, } \\
\text { map } 5\end{array}$ & $\begin{array}{l}64.2128,-149,3082 \text { and } \\
64.2278,-149.2588\end{array}$ \\
\hline 121 & $\begin{array}{l}\text { Riley Creek outwash (stage 2) (Wahrhaftig, 1970b; } \\
\text { Kachadoorian, 1960) }\end{array}$ & $\begin{array}{l}\text { sheet 2, } \\
\text { map } 5\end{array}$ & $\begin{array}{l}64.2618,-149.2410 \text { and } \\
64.2692,-149.1653\end{array}$ \\
\hline 123 & Outwash fan & $\begin{array}{l}\text { sheet 2, } \\
\text { map } 5\end{array}$ & $\begin{array}{l}\text { 64.2784, }-149.0863 ; 64.2982, \\
-149.0600 ; \text { and } 64.3200, \\
-149.0683\end{array}$ \\
\hline 124 & Distal alluvial-fan complex & $\begin{array}{l}\text { sheet 2, } \\
\text { map } 5\end{array}$ & $64.4499,-149.0455$ \\
\hline
\end{tabular}




\begin{tabular}{|c|c|c|c|}
\hline Symbol & Definition & $\begin{array}{l}\text { Map } \\
\text { Sheet }\end{array}$ & Lat/Long ${ }^{1}$ \\
\hline 125 & $\begin{array}{l}\text { Complex of fine-grained, frozen, distal alluvial fan sedi- } \\
\text { ments with interwoven sandy, frozen channel fills, and } \\
\text { frozen organic swamp deposits (Rawlinson, 1987) }\end{array}$ & $\begin{array}{l}\text { sheet 2, } \\
\text { map } 5\end{array}$ & $64.4499,-149.0455$ \\
\hline $131 a$ & Fluvial terrace scarp & $\begin{array}{l}\text { sheet } 2 \text {, } \\
\text { map } 5\end{array}$ & $64.6915,-149.9798$ \\
\hline 134 & Thermokarst-modified thaw lake & $\begin{array}{l}\text { sheet 2, } \\
\text { map } 5\end{array}$ & $\begin{array}{l}64.7302,-148.8727 \text { and } \\
64.8391,-148.7864\end{array}$ \\
\hline 135 & Thermokarst-modified Elr & $\begin{array}{l}\text { sheet 2, } \\
\text { map } 5\end{array}$ & $\begin{array}{l}64.7566,-148.7601 ; \\
64.8105,-148.7661 ; \\
64.7967,-148.7772 ; \text { and } \\
64.9501,-148.6731\end{array}$ \\
\hline 145 & River-cut scarp & $\begin{array}{l}\text { sheet 2, } \\
\text { map } 5\end{array}$ & $64.7964,-148.8643$ \\
\hline 148 & Tolovana landslide (Mertie, 1937) & $\begin{array}{l}\text { sheet 2, } \\
\text { map } 6\end{array}$ & $65.1209,-148.7196$ \\
\hline 149 & $\begin{array}{l}\text { Undifferentiated, mainly non-calcareous sedimentary rocks } \\
\text { of mid-Paleozoic age (Mertie, 1937) }\end{array}$ & $\begin{array}{l}\text { sheet 2, } \\
\text { map } 6\end{array}$ & $65.1349,-148.7277$ \\
\hline 150 & Thermokarst-modified floodplain-marginal lakes & $\begin{array}{l}\text { sheet 2, } \\
\text { map } 6\end{array}$ & $65.2230,-148.7065$ \\
\hline 154 & $\begin{array}{l}\text { Thermokarst-modified, coarse-grained alluvial fan (Ffg) with } \\
\text { surface cover of Ell + Elr }\end{array}$ & $\begin{array}{l}\text { sheet 2, } \\
\text { map 6 }\end{array}$ & $65.4389,-148.6091$ \\
\hline 161 & High-level weathered strath terrace gravels of Tertiary age & $\begin{array}{l}\text { sheet 2, } \\
\text { map } 6\end{array}$ & $65.5147,-148.817$ \\
\hline 163 & Flood scoured cliffs and scablands along Yukon River & $\begin{array}{l}\text { sheet } 3 \\
\text { map } 7\end{array}$ & $\begin{array}{l}65.8782,-149.5705 ; \\
65.8806,-149.6493 ; \\
65.8739,-149.7536 ; \\
65.8553,-149.8129 ; \\
65.8483,-149.8704 ; \\
65.8880,-149.7124 ; \\
65.8908,-149.7425 ; \\
65.8908,-149.7586 ; \\
65.8966,-149.7862 ; \\
65.8744,-149.8402 ; \text { and } \\
65.8768,-149.8529\end{array}$ \\
\hline 164 & $\begin{array}{l}\text { Major floodway for overflow from Old Crow basin via Porcu- } \\
\text { pine River (Thorson and Dixon, 1983) and outburst floods } \\
\text { from the Yukon-Tanana Upland (Froese and others, 2003) }\end{array}$ & $\begin{array}{l}\text { sheet } 3 \text {, } \\
\text { map } 7\end{array}$ & $\begin{array}{l}65.8857,-149.5550 \text { and } \\
65.8677,-149.7799\end{array}$ \\
\hline 166 & $\begin{array}{l}\text { Thick, fine-grained slackwater basin sediments deposited } \\
\text { during massive flooding from up Yukon River }\end{array}$ & $\begin{array}{l}\text { sheet 3, } \\
\text { map } 7\end{array}$ & $65.8921,-149.8181$ \\
\hline 168 & Rock quarry & $\begin{array}{l}\text { sheet } 3 \\
\text { map } 7\end{array}$ & $\begin{array}{l}65.9259,-149.7735 \\
65.9626,-149.9174 ; \text { and } \\
66.2423,-150.2870\end{array}$ \\
\hline 169 & Coldwater springs & $\begin{array}{l}\text { sheet 3, } \\
\text { map } 7\end{array}$ & $65.9650,-150.0097$ \\
\hline 171 & $\mathrm{GF}+\mathrm{L}$ (ice-marginal sediments) & $\begin{array}{l}\text { sheet 3, } \\
\text { map } 8\end{array}$ & $66.7681,-150.6733$ \\
\hline 172 & $\begin{array}{l}\text { Southern limit of Kobuk glaciation from Brooks Range } \\
\text { (Hamilton, 1982; Brown and Kreig, 1983, p.113) }\end{array}$ & $\begin{array}{l}\text { sheet } 3 \text {, } \\
\text { map } 8\end{array}$ & $66.7801,-150.6672$ \\
\hline
\end{tabular}




\begin{tabular}{|c|c|c|c|}
\hline Symbol & Definition & $\begin{array}{l}\text { Map } \\
\text { Sheet }\end{array}$ & Lat/Long ${ }^{1}$ \\
\hline 173 & $\begin{array}{l}\text { Terminal moraine of late Wisconsin early Itkillik glaciation } \\
\text { (Hamilton, 1979, 1982) }\end{array}$ & $\begin{array}{l}\text { sheet } 3 \text {, } \\
\text { map } 8\end{array}$ & $67.0650,-150.3184$ \\
\hline \multirow[t]{3}{*}{174} & \multirow[t]{3}{*}{$\begin{array}{l}\text { Massive ground ice bodies represent buried late Wisconsin } \\
\text { (Itkillik) glacial ice preserved in permafrost; note numerous } \\
\text { actively thermokarsting kettle lakes }\end{array}$} & $\begin{array}{l}\text { sheet } 3 \text {, } \\
\text { map } 8\end{array}$ & $67.0733,-150.3347$ \\
\hline & & $\begin{array}{l}\text { sheet } 4, \\
\text { map } 10\end{array}$ & $\begin{array}{l}68.3922,-149.3448 ; \\
68.4051,-149.3806 ; \\
68.4108,-149.3624 ; \\
68.4140,-149.3935 ; \\
68.4281,-149.4004 ; \\
68.4352,-149.3934 ; \\
68.4744,-149.4639 ; \\
68.4870,-149.4701 ; \text { and } \\
68.4863,-149.4854\end{array}$ \\
\hline & & $\begin{array}{l}\text { sheet } 4, \\
\text { map } 11\end{array}$ & $68.8625,-148.8654$ \\
\hline 175 & $\begin{array}{l}\text { Floodplain scour associated with thick, seasonal stream } \\
\text { icings }\end{array}$ & $\begin{array}{l}\text { sheet } 3 \text {, } \\
\text { map } 9\end{array}$ & $\begin{array}{l}67.2034,-150.3181 \text { and } \\
67.4551,-150.0605\end{array}$ \\
\hline 176 & $\begin{array}{l}\text { Braided floodplains subject to annual floodplain icings } \\
\text { in main channel and at mouths of some tributary streams } \\
\text { (Sloan and others, 1976; fig. 14) }\end{array}$ & $\begin{array}{l}\text { sheet } 3 \text {, } \\
\text { map } 9\end{array}$ & $67.2066,-150.3123$ \\
\hline 177 & $\begin{array}{l}\text { Limit of middle Itkillik (late Wisconsin) glaciation (Hamilton, } \\
\text { 1979) }\end{array}$ & $\begin{array}{l}\text { sheet 3, } \\
\text { map } 9\end{array}$ & $\begin{array}{l}67.3285,-150.1419 \text { and } \\
67.3364,-150.1890\end{array}$ \\
\hline 178 & Limit of late Itkillik re-advance (Hamilton, 1979) & $\begin{array}{l}\text { sheet } 3 \text {, } \\
\text { map } 9\end{array}$ & $\begin{array}{l}67.3812,-150.1114 \text { and } \\
67.3815,-150.1438\end{array}$ \\
\hline 179 & $\begin{array}{l}\text { Fine-grained alpine fans exhibit axial troughs and natural } \\
\text { levees of mudflow complexes (Kreig and Reger, 1982, plate } \\
\text { 24) }\end{array}$ & $\begin{array}{l}\text { sheet } 4 \\
\text { map } 10\end{array}$ & $68.2718,-149.3836$ \\
\hline 181 & Bimodal failure & $\begin{array}{l}\text { sheet } 4 \text {, } \\
\text { map } 10\end{array}$ & $68.4192,-149.3969$ \\
\hline 182 & Parabolic sand dunes (Kreig and Reger, 1982, plate 25) & $\begin{array}{l}\text { sheet } 4 \\
\text { map } 10\end{array}$ & $68.4310,-149.3951$ \\
\hline 183 & Atigun Gorge; site of glacier-impounded meltwater lake & $\begin{array}{l}\text { sheet } 4 \\
\text { map } 10\end{array}$ & $68.4574,-149.3335$ \\
\hline 184 & Thermoerosion scarp & $\begin{array}{l}\text { sheet } 4 \\
\text { map } 10\end{array}$ & $68.4704,-149.4551$ \\
\hline 185 & Ice-scoured bedrock & $\begin{array}{l}\text { sheet } 4 \\
\text { map } 10\end{array}$ & $68.5090,-149.4446$ \\
\hline 187 & Drift of late Itkillik glaciation & $\begin{array}{l}\text { sheet } 4 \\
\text { map } 10\end{array}$ & $68.5246,-149.4350$ \\
\hline 189 & Probable flood fan & $\begin{array}{l}\text { sheet } 4, \\
\text { map } 10\end{array}$ & $68.6141,-149.4706$ \\
\hline 190 & Numerous flood cobbles and boulders likely; flood course & $\begin{array}{l}\text { sheet } 4 \\
\text { map } 10\end{array}$ & $68.6090,-149.4903$ \\
\hline 191 & Young Sagavanirktok River moraines of Kuparuk River lobe & $\begin{array}{l}\text { sheet } 4 \text {, } \\
\text { map } 10\end{array}$ & $68.6493,-149.4861$ \\
\hline
\end{tabular}




\begin{tabular}{|c|c|c|c|}
\hline Symbol & Definition & $\begin{array}{l}\text { Map } \\
\text { Sheet }\end{array}$ & Lat/Long ${ }^{1}$ \\
\hline 192 & Atigun Valley lobe; early Itkillik moraine (Hamilton, 1978b) & $\begin{array}{l}\text { sheet } 4 \\
\text { map } 10\end{array}$ & $68.6370,-149.5417$ \\
\hline 193 & Probable floodway channel & $\begin{array}{l}\text { sheet } 4, \\
\text { map } 10\end{array}$ & $68.6234,-149.3773$ \\
\hline \multirow[t]{2}{*}{194} & $\begin{array}{l}\text { Sagavanirktok River lateral moraine of the Sagavanirktok } \\
\text { River lobe (Hamilton, 1978b, 2002) }\end{array}$ & $\begin{array}{l}\text { sheet } 4, \\
\text { map } 10\end{array}$ & $68.6611,-149.3710$ \\
\hline & & $\begin{array}{l}\text { sheet 4, } \\
\text { map } 11\end{array}$ & $\begin{array}{l}68.6804,-149.2180 \text { and } \\
68.8409,-148.9263\end{array}$ \\
\hline 196 & $\begin{array}{l}\text { Western limit of Itkillik moraine of the Sagavanirktok River } \\
\text { lobe (Hamilton, 1978b) }\end{array}$ & $\begin{array}{l}\text { sheet } 4 \text {, } \\
\text { map } 11\end{array}$ & $68.6972,-149.0741$ \\
\hline 197 & $\begin{array}{l}\text { Proximal outwash of Itkillik advance of Sagavanirktok River } \\
\text { lobe (Hamilton, 2002) }\end{array}$ & $\begin{array}{l}\text { sheet 4, } \\
\text { map } 11\end{array}$ & $68.7999,-148.8625$ \\
\hline 198 & $\begin{array}{l}\text { Former ice-rich roadcut (Kreig and Reger 1982, plate 28, } \\
\text { fig. 13) }\end{array}$ & $\begin{array}{l}\text { sheet 4, } \\
\text { map } 11\end{array}$ & $69.0224,-148.8418$ \\
\hline 199 & Fillings of Yedoma (y) depressions (Cx) & $\begin{array}{l}\text { sheet } 4, \\
\text { map } 11\end{array}$ & $69.0419,-148.8665$ \\
\hline 200 & Northern limit of glacial till along Dalton Highway & $\begin{array}{l}\text { sheet } 4 \text {, } \\
\text { map } 11\end{array}$ & $69.2110,-148.7988$ \\
\hline 201 & Thermokarst-modified stream valley & $\begin{array}{l}\text { sheet } 4, \\
\text { map } 11\end{array}$ & $69.4659,-148.6766$ \\
\hline $201 a$ & Thermokarst-modified stream channel & $\begin{array}{l}\text { sheet } 4, \\
\text { map } 12\end{array}$ & $69.9847,-148.7100$ \\
\hline 203 & $\begin{array}{l}\text { Thermokarst-modified flood channels (Kreig and Reger, } \\
\text { 1982, plate 29) }\end{array}$ & $\begin{array}{l}\text { sheet } 4, \\
\text { map } 12\end{array}$ & $\begin{array}{l}\text { 69.8974,-148.7671; } \\
69.9023,-148.7780 ; \\
69.9126,-148.7636 ; \\
69.9260,-148.7465 ; \text { and } \\
69.9340,-148.8190\end{array}$ \\
\hline 204 & Snowdrifts along TAPS & $\begin{array}{l}\text { sheet } 4, \\
\text { map } 12\end{array}$ & $70.1370,-148.6232$ \\
\hline 205 & Bedrock contact (Patton and Miller, 1973) & $\begin{array}{l}\text { sheet 3, } \\
\text { map } 8\end{array}$ & $66.4806,-150.6731$ \\
\hline 206 & Massive landslide in thick till of Elmendorf age & $\begin{array}{l}\text { sheet } 1 \text {, } \\
\text { map } 3\end{array}$ & $62.8008,-149.9679$ \\
\hline 207 & Terrace with numerous flood boulders & $\begin{array}{l}\text { sheet } 1 \text {, } \\
\text { map } 2\end{array}$ & $62.5502,-150.2403$ \\
\hline 208 & $\begin{array}{l}\text { Melting of ice-rich permafrost in palsa crossed by Parks } \\
\text { Highway, causing chronic road stability problems }\end{array}$ & $\begin{array}{l}\text { sheet } 1 \text {, } \\
\text { map } 3\end{array}$ & $63.3674,-149.0011$ \\
\hline 209 & Shutter ridge along Denali fault & $\begin{array}{l}\text { sheet 2, } \\
\text { map } 4\end{array}$ & $63.4538,-148.7903$ \\
\hline 210 & Series of landslides along Denali fault & $\begin{array}{l}\text { sheet 2, } \\
\text { map } 4\end{array}$ & $63.4535,-148.7824$ \\
\hline 211 & Small slump in quasi-stable talus cone & $\begin{array}{l}\text { sheet 2, } \\
\text { map } 4\end{array}$ & $63.4919,-148.8089$ \\
\hline 212 & $\begin{array}{l}\text { Debris fan probably deposited during breaching of avalanche } \\
\text { deposit by impounded lake waters }\end{array}$ & $\begin{array}{l}\text { sheet 2, } \\
\text { map } 4\end{array}$ & $63.5011,-148.8226$ \\
\hline
\end{tabular}




\begin{tabular}{|c|c|c|c|}
\hline Symbol & Definition & $\begin{array}{l}\text { Map } \\
\text { Sheet }\end{array}$ & Lat/Long ${ }^{1}$ \\
\hline 217 & High-level Healy or Dry Creek outwash & $\begin{array}{l}\text { sheet } 2 \text {, } \\
\text { map } 4\end{array}$ & $64.0074,-149.1512$ \\
\hline 219 & $\begin{array}{l}\text { Thick, ice-rich, fine-grained glaciolacustrine sediments at } \\
\text { depth }\end{array}$ & $\begin{array}{l}\text { sheet } 3 \text {, } \\
\text { map } 9\end{array}$ & $67.4121,-150.0808$ \\
\hline 220 & $\begin{array}{l}\text { Residual foothills of broad eolian sand sheet with consider- } \\
\text { able ground ice (Rawlinson, 1983; Carter and Robinson, } \\
\text { 1981) }\end{array}$ & $\begin{array}{l}\text { sheet } 4 \\
\text { map } 12\end{array}$ & $69.5651,-148.7706$ \\
\hline 221 & Ice-rich colluvial basin filling (Kreig and Reger, 1982) & $\begin{array}{l}\text { sheet } 3 \text {, } \\
\text { map } 7\end{array}$ & $66.2425,-150.3183$ \\
\hline 222 & $\begin{array}{l}\text { Bench-shaped frozen debris flow over till of the Itkillik gla- } \\
\text { ciation (Cdf); mapped as cl by Hamilton (1978a) }\end{array}$ & $\begin{array}{l}\text { sheet } 3 \text {, } \\
\text { map } 9\end{array}$ & $67.5538,-149.8812$ \\
\hline 223 & $\begin{array}{l}\text { Lobate frozen debris flow (Cdf); mapped as cg by Hamilton } \\
\text { (1978a) }\end{array}$ & $\begin{array}{l}\text { sheet } 3 \text {, } \\
\text { map } 9\end{array}$ & $67.4931,-149.9101$ \\
\hline 225 & Thin-skinned thaw failure in till of Itkillik glaciation & $\begin{array}{l}\text { sheet } 3 \text {, } \\
\text { map } 9\end{array}$ & $\begin{array}{l}67.4662,-150.0790 \text { and } \\
67.4699,-150.0680\end{array}$ \\
\hline 227 & Incipient unconfined frozen debris-flow slide (Cdf) & $\begin{array}{l}\text { sheet } 3 \text {, } \\
\text { map } 9\end{array}$ & $67.6478,-149.7791$ \\
\hline & & $\begin{array}{l}\text { Sheet 4, } \\
\text { Map } 10\end{array}$ & $67.8652,-149.8633$ \\
\hline 229 & $\begin{array}{l}\text { Known active confined tongue of frozen flowslide deposit, } \\
\text { potential impacts to Dalton Highway and TAPS }\end{array}$ & $\begin{array}{l}\text { sheet } 3 \text {, } \\
\text { map } 9\end{array}$ & $67.8119,-149.8136$ \\
\hline 230 & Incipient rock glacier & $\begin{array}{l}\text { sheet } 4 \text {, } \\
\text { map } 10\end{array}$ & $68.1265,-149.4400$ \\
\hline 231 & $\begin{array}{l}\text { High marginal ridges indicate thawing of interstitial and } \\
\text { core ice in this and other rock glaciers in upper Atigun River } \\
\text { valley }\end{array}$ & $\begin{array}{l}\text { sheet } 4 \\
\text { map } 10\end{array}$ & $68.1366,-149.4370$ \\
\hline 232 & Massive landslide complex in bedrock (Hamilton, 1978b) & $\begin{array}{l}\text { sheet } 4 \\
\text { map } 10\end{array}$ & $68.0358,-149.6993$ \\
\hline 233 & $\begin{array}{l}\text { Active landslide in fine-grained glaciolacustrine sediments } \\
\text { (Wahrhaftig and Black, 1958) }\end{array}$ & $\begin{array}{l}\text { sheet 2, } \\
\text { map } 4\end{array}$ & $63.7526,-148.9100$ \\
\hline 234 & Horsetail drainage in active layer above permafrost & $\begin{array}{l}\text { sheet } 4 \text {, } \\
\text { map } 10\end{array}$ & $68.5905,-149.4597$ \\
\hline 235 & $\begin{array}{l}\text { Pitted outwash of Elmendorf stade overlying ice-stagnation } \\
\text { deposits of Skilak stade }\end{array}$ & $\begin{array}{l}\text { sheet } 1 \text {, } \\
\text { map } 2\end{array}$ & $62.1308,-150.0612$ \\
\hline 236 & Hanging delta of Carlo age & $\begin{array}{l}\text { sheet 2, } \\
\text { map } 4\end{array}$ & $63.6581,-148.7517$ \\
\hline 237 & Granitic bedrock eminences (tors) & $\begin{array}{l}\text { sheet 3, } \\
\text { map } 8\end{array}$ & $\begin{array}{l}66.3698,-150.4857 ; \\
66.3708,-150.4869 ; \\
66.3744,-150.4877 ; 66.3752, \\
-150.4916 ; 66.3768, \\
-150.5115 ; 66.3831 \\
-150.5053 ; \text { and } 66.3843, \\
-150.5046\end{array}$ \\
\hline
\end{tabular}

${ }^{1}$ The coordinate system for the points in this table is the Geographic Coordinate System: GCS_North_American_1983; datum: D_North_American_1983 


\begin{tabular}{|c|c|}
\hline Symbol & Definition \\
\hline$b$ & Bedrock \\
\hline$b^{\prime}$ & Shallow bedrock \\
\hline$b+b^{\prime}$ & Bedrock + shallow bedrock \\
\hline bw & Weathered bedrock \\
\hline $\mathrm{bw}(\mathrm{Ts})$ & Weathered bedrock ( $\mathrm{Ts}=$ bedded Tertiary sedimentary bedrock) \\
\hline $\mathrm{Ca}$ & Snow-avalanche deposits \\
\hline Cas & Slush-flow deposits \\
\hline $\mathrm{Cd}$ & Debris-flow deposits \\
\hline Cdf & $\begin{array}{l}\text { Frozen debris flow deposits, includes bench shaped (unconfined) and narrow tongue shaped (con- } \\
\text { fined) flowslides. Commonly creeping. Characterized by unsorted, non-stratified, angular to suban- } \\
\text { gular rubble with fine-grained matrix, common on schist and locally present on slate, limestone, and } \\
\text { hornfels (Hamilton, 1978a) }\end{array}$ \\
\hline Cf & $\begin{array}{l}\text { Colluvium intricately mixed with coarse, angular bedrock fragments in upper drainages of small upland } \\
\text { tributaries }\end{array}$ \\
\hline Cfd & $\begin{array}{l}\text { Alpine fans formed at the mouths of rock-walled valleys and composed of debris-flow, mudflow, snow } \\
\text { avalanche, and slush-flow deposits }\end{array}$ \\
\hline $\mathrm{Cg}$ & $\begin{array}{l}\text { Rock glacier composed primarily of angular rock fragments; where active, has steep lateral and termi- } \\
\text { nal scarps and indicates the presence of permafrost; could be derived from accumulation of talus at the } \\
\text { base of steep bedrock slopes or from thinning and recession of valleyhead glaciers }\end{array}$ \\
\hline $\mathrm{Cl}$ & Landslide in surficial deposits and/or weathered bedrock \\
\hline $\mathrm{Cl}$ in bc & Landslide in fine-grained, glacioestuarine deposits of Bootlegger Cove Formation \\
\hline $\mathrm{Cl}$ in bw & Landslide in weathered bedrock \\
\hline $\mathrm{Clr}$ & Retrogressive flow-slide deposits (bimodal failure) \\
\hline $\mathrm{Cm}$ & Mudflow deposits \\
\hline $\mathrm{Cs}$ & Gelifluction/solifluction deposits \\
\hline $\mathrm{Cs} / \mathrm{b}$ & Gelifluction/solifluction deposits over bedrock \\
\hline $\mathrm{Cs} / \mathrm{gt}$ & Gelifluction/solifluction deposits over glacial till \\
\hline $\mathrm{Ct}$ & $\begin{array}{l}\text { Talus cone or apron; composed of angular rock fragments pried by frost wedging from bedrock surfaces } \\
\text { upslope and deposited by gravity-influenced sporadic falling, tumbling, bouncing, and sliding }\end{array}$ \\
\hline$C x$ & $\begin{array}{l}\text { Complex fillings of thermokarst basins in ice-rich eolian and glacial deposits (yedoma) north of the central } \\
\text { Brooks Range in the Arctic Foothills and Arctic Coastal Plain; consist of ice-rich, peaty colluvium and eolian } \\
\text { sediments }\end{array}$ \\
\hline$C x+L t$ & $\begin{array}{l}\text { Complex fillings of thermokarst basins in ice-rich eolian and glacial deposits (yedoma) north of the central } \\
\text { Brooks Range in the Arctic Foothills and Arctic Coastal Plain; consist of ice-rich, peaty colluvium and eolian } \\
\text { sediments + thaw-lake deposits }\end{array}$ \\
\hline Ell & Lowland loess; typically mixed with retransported eolian silt and sand \\
\hline Ell/Fp & $\begin{array}{l}\text { Lowland loess; typically mixed with retransported eolian silt and sand over undifferentiated floodplain al- } \\
\text { luvium }\end{array}$ \\
\hline $\begin{array}{l}\text { Ell+Lto/ } \\
\text { Mc }\end{array}$ & $\begin{array}{l}\text { Lowland loess; typically mixed with retransported eolian silt and sand }+ \text { deposits of oriented thaw lake } \\
\text { over marine deposits of Arctic Coastal Plain }\end{array}$ \\
\hline $\begin{array}{l}\text { Ell+Lto/ } \\
\text { Mc? }\end{array}$ & $\begin{array}{l}\text { Lowland loess; typically mixed with retransported eolian silt and sand }+ \text { deposits of oriented thaw lake } \\
\text { over possible marine deposits of Arctic Coastal Plain }\end{array}$ \\
\hline Elr & $\begin{array}{l}\text { Silt and organic silt retransported by hyperconcentrated flows when upland loess is dissected, locally form- } \\
\text { ing residual silty flatirons, and redeposited as silt-rich alluvial fans on lower slopes and in valley bottoms; } \\
\text { intricately mixed with lowland loess }\end{array}$ \\
\hline
\end{tabular}




\begin{tabular}{|c|c|}
\hline Symbol & Definition \\
\hline Elr/b & $\begin{array}{l}\text { Silt and organic silt retransported by hyperconcentrated flows when upland loess is dissected, locally } \\
\text { forming residual silty flatirons, and redeposited as silt-rich alluvial fans on lower slopes and in valley } \\
\text { bottoms; intricately mixed with lowland loess over bedrock }\end{array}$ \\
\hline elr+cs & $\begin{array}{l}\text { Silt and organic silt retransported by hyperconcentrated flows when upland loess is dissected, locally } \\
\text { forming residual silty flatirons, and redeposited as silt-rich alluvial fans on lower slopes and in valley } \\
\text { bottoms; intricately mixed with lowland loess + undifferentiated colluvium }\end{array}$ \\
\hline $\mathrm{Elr}+\mathrm{Cs}$ & $\begin{array}{l}\text { Silt and organic silt retransported by hyperconcentrated flows when upland loess is dissected, locally } \\
\text { forming residual silty flatirons, and redeposited as silt-rich alluvial fans on lower slopes and in valley } \\
\text { bottoms; intricately mixed with lowland loess + gelifluction/solifluction deposits. Also labeled as Elr + C }\end{array}$ \\
\hline Elr+Elx & $\begin{array}{l}\text { Silt and organic silt retransported by hyperconcentrated flows when upland loess is dissected, locally } \\
\text { forming residual silty flatirons, and redeposited as silt-rich alluvial fans on lower slopes and in valley } \\
\text { bottoms; intricately mixed with lowland loess + frozen silty upland loess with moderate to high ice con- } \\
\text { tent, including yedoma (Shur and others, 2010; Kanevskiy and others, 2011); contains large, dominantly } \\
\text { syngenetic and lesser epigenetic ice wedges }\end{array}$ \\
\hline Elx & $\begin{array}{l}\text { Frozen silty upland loess with moderate to high ice content, including yedoma (Shur and others, 2010; } \\
\text { Kanevskiy and others, 2011); contains large, dominantly syngenetic and lesser epigenetic ice wedges }\end{array}$ \\
\hline$E \mid x / b$ & $\begin{array}{l}\text { Frozen silty upland loess with moderate to high ice content, including yedoma (Shur and others, 2010; } \\
\text { Kanevskiy and others, 2011); contains large, dominantly syngenetic and lesser epigenetic ice wedges } \\
\text { over bedrock }\end{array}$ \\
\hline Elx/bw & $\begin{array}{l}\text { Frozen silty upland loess with moderate to high ice content, including yedoma (Shur and others, 2010; } \\
\text { Kanevskiy and others, 2011); contains large, dominantly syngenetic and lesser epigenetic ice wedges } \\
\text { over weathered bedrock }\end{array}$ \\
\hline $\mathrm{El} / \mathrm{Gt}$ & $\begin{array}{l}\text { Frozen silty upland loess with moderate to high ice content, including yedoma (Shur and others, 2010; } \\
\text { Kanevskiy and others, 2011); contains large, dominantly syngenetic and lesser epigenetic ice wedges } \\
\text { over glacial till }\end{array}$ \\
\hline Elx+Elr & $\begin{array}{l}\text { Frozen silty upland loess with moderate to high ice content, including yedoma (Shur and others, 2010; } \\
\text { Kanevskiy and others, 2011); contains large, dominantly syngenetic and lesser epigenetic ice wedges } \\
\text { + silt and organic silt retransported by hyperconcentrated flows when upland loess is dissected, locally } \\
\text { forming residual silty flatirons, and redeposited as silt-rich alluvial fans on lower slopes and in valley } \\
\text { bottoms; intricately mixed with lowland loess }\end{array}$ \\
\hline Es & Sand dunes or sand dune complex \\
\hline $\mathrm{F}+\mathrm{L}$ & Undifferentiated fluvial deposits + fine-grained lacustrine deposits \\
\hline $\mathrm{Fab}$ & Abandoned-floodplain deposits \\
\hline Fac & Abandoned-meltwater-channel deposits; may occupy floodways related to past massive flooding \\
\hline $\mathrm{Fac}+\mathrm{Elr}$ & $\begin{array}{l}\text { Fans and aprons of alluvium and colluvium derived from weathering of upland bedrock + silt and } \\
\text { organic silt retransported by hyperconcentrated flows when upland loess is dissected, locally forming } \\
\text { residual silty flatirons, and redeposited as silt-rich alluvial fans on lower slopes and in valley bottoms; } \\
\text { intricately mixed with lowland loess }\end{array}$ \\
\hline Fat & Fluvial terrace \\
\hline Fato & High-level ancient fluvial terrace in Ray River drainage (Kreig and Reger, 1982, plate 14) \\
\hline $\mathrm{Fd}$ & $\begin{array}{l}\text { Fan-delta sands related to glaciomarine invasion of lower Susitna River basin during late Naptowne } \\
\text { glaciation (Skilak and Elmendorf stades); forms broad braidplain between Elmendorf terminal moraine } \\
\text { of Matanuska Valley and Knik River lobes and lower Susitna River }\end{array}$ \\
\hline $\mathrm{Fd} / \mathrm{bc}$ & $\begin{array}{l}\text { Fan-delta sands related to glaciomarine invasion of lower Susitna River basin during late Naptowne } \\
\text { glaciation (Skilak and Elmendorf stades); forms broad braidplain between Elmendorf terminal moraine of } \\
\text { Matanuska Valley and Knik River lobes and lower Susitna River over fine-grained, glacioestuarine deposits } \\
\text { of Bootlegger Cove Formation }\end{array}$ \\
\hline $\mathrm{Ff}$ & Fine-grained alluvial fan \\
\hline
\end{tabular}




\begin{tabular}{|c|c|}
\hline Symbol & Definition \\
\hline $\mathrm{Ff}+\mathrm{Ca}$ & Fine-grained alluvial fan and snow-avalanche deposits \\
\hline $\mathrm{Ff}+\mathrm{Cm}$ & Fine-grained alluvial fan and mudflow deposits \\
\hline $\mathrm{Ffg}$ & Coarse-grained alluvial fan; typically contains debris-flow deposits in upper fan \\
\hline $\mathrm{Fp}$ & Undifferentiated floodplain alluvium \\
\hline $\mathrm{Fpb}$ & Undifferentiated floodplain alluvium over bedrock \\
\hline $\mathrm{Fp} / \mathrm{Mc}$ & Undifferentiated floodplain alluvium over marine deposits of Arctic Coastal Plain \\
\hline $\mathrm{Fpb}$ & Floodplain alluvium of braided stream \\
\hline Fpm & Floodplain alluvium of meandering stream \\
\hline $\mathrm{G}+\mathrm{GF}$ & Undifferentiated glacial deposits + undifferentiated glaciofluvial deposits \\
\hline GF & Undifferentiated glaciofluvial deposits \\
\hline GFk & Kame-esker glaciofluvial complex, kame terraces, eskers, and kame-esker glaciofluvial complexes \\
\hline GFo & Coarse-grained outwash alluvium \\
\hline GFop & Pitted coarse-grained outwash alluvium \\
\hline Gt & Glacial till \\
\hline $\mathrm{Gt} / \mathrm{b}$ & Glacial till over bedrock \\
\hline $\mathrm{Gt}+\mathrm{L}$ & Glacial till + fine-grained glaciolacustrine deposits \\
\hline $\mathrm{H}$ & Artificial fill material \\
\hline $\mathrm{Hp}$ & Placer mine or mines; both active and inactive \\
\hline Lt & Thaw-lake deposits \\
\hline Lto & Deposits of oriented thaw lake \\
\hline $\mathrm{O} / \mathrm{GL}$ & Peat or organic deposit over fine-grained glaciolacustrine deposits \\
\hline $\mathrm{p}$ & Open-system pingo; small hill or former hill cored with ice lens \\
\hline p.s. 6 & Trans-Alaska Pipeline System (TAPS) pump station, numbered successively from north to south \\
\hline pa & Palsas; perennially frozen peat mound; when expanded in area, form peat plateaus \\
\hline $\mathrm{pc}$ & Closed-system pingo \\
\hline $\mathrm{pg}$ & $\begin{array}{l}\text { Polygonal ground, both low- and high-center polygons formed at the ground surface by development of } \\
\text { ice-wedge networks in permafrost or their former presence, respectively }\end{array}$ \\
\hline $\mathrm{pt}$ & Peat, locally thick, and related fine-grained paludal sediments, string bogs, or strangamoor \\
\hline$T$ & Thermokarst pond, lake, or depression; includes thaw basins formed by the melting of ice-rich permafrost \\
\hline VSM & Vertical support member for elevated pipeline \\
\hline $\mathrm{y}$ & Yedoma may be former open-system pingos (numerous cold-water springs) \\
\hline
\end{tabular}




\section{APPENDIX B. LIST OF REFERENCES FOR PREVIOUSLY MAPPED FAULTS SHOWN ON MAP SHEETS 1-4}

Albert, N.R.D., Le Compte, J.R., and Steele, W.C., 1978, Map showing interpretation of Landsat imagery of the Chandalar Quadrangle, Alaska: U.S. Geological Survey Miscellaneous Field Studies Map 878-J, 2 sheets, scale 1:250,000. http://dggs.alaska.gov/pubs/id/13354

Athey, J.E., Newberry, R.J., Werdon, M.B., Freeman, L.K., Smith, R.L., and Szumigala, D.J., 2006, Bedrock geologic map of the Liberty Bell area, Fairbanks A-4 Quadrangle, Bonnifield mining district, Alaska: Alaska Division of Geological \& Geophysical Surveys Report of Investigation 2006-2 v. 1.0.1, 98 p., 1 sheet, scale 1:50,000. http://doi.org/10.14509/15026

Athey, J.E., Szumigala, D.J., Newberry, R.J., Werdon, M.B., and Hicks, S.A., 2004, Bedrock geologic map of the Livengood SW C-3 and SE C-4 quadrangles, Tolovana mining district, Alaska: Alaska Division of Geological \& Geophysical Surveys Preliminary Interpretive Report 2004-3B, 1 sheet, scale 1:50,000. http://doi. org/10.14509/3310

Barnes, F.F., 1953, Preliminary report on the Little Susitna district, Matanuska coal field, Alaska: U.S. Geological Survey Open-File Report 53-10, 14 p., 1 sheet, scale 1:4. http://dggs.alaska.gov/ pubs/id/10541

Brosgé, W.P., and Reiser, H.N., 1964, Geologic map and section of the Chandalar Quadrangle, Alaska: U.S. Geological Survey Miscellaneous Geologic Investigations Map 375, 1 sheet, scale 1:250,000. http://dggs.alaska.gov/pubs/ id/12869

1971, Preliminary bedrock geologic map, Wiseman and eastern Survey Pass quadrangles, Alaska-Map and explanation: U.S. Geological Survey Open File Report: Technical Data Unit classification number 479, 2 sheets. http://dggs. alaska.gov/pubs/id/13824

Brosgé, W.P., Reiser, H.N., Dutro, J.T., Jr., and Detterman, R.L., 1979, Bedrock geologic map of the Philip Smith Mountains Quadrangle, Alaska: U.S. Geological Survey Miscellaneous Field
Studies Map 879-B, 2 sheets, scale 1:250,000. http://dggs.alaska.gov/pubs/id/13356

Bundtzen, T.K., 1982, Bedrock geology of the Fairbanks mining district, western sector: Alaska Division of Geological \& Geophysical Surveys Alaska Open-File Report 155, 2 sheets, scale 1:24,000. http://doi.org/10.14509/89

Capps, S.R., 1933, The eastern portion of Mount McKinley National Park, in U.S. Geological Survey, Mineral resources of Alaska, report on progress of investigations in 1930: U.S. Geological Survey Bulletin 836, p. 219-300, 1 sheet, scale 1:250,000. http://dggs.alaska.gov/pubs/ id/4612

1940, Geology of the Alaska Railroad region: U.S. Geological Survey Bulletin 907, 201 p., 3 sheets, scale 1:250,000. http://dggs.alaska. gov/pubs/id/3457

Clautice, K.H., Newberry, R.J., Blodgett, R.B., Bundtzen, T.K., Gage, B.G., Harris, E.E., Liss, S.A., Miller, M.L., Reifenstuhl, R.R., Clough, J.G., and Pinney, D.S., 2001, Bedrock geologic map of the Chulitna region, south-central Alaska: Alaska Division of Geological \& Geophysical Surveys Report of Investigation 20011A, 31 p., 1 sheet, scale 1:63,360. http://doi. org/10.14509/2768

Csejtey, Béla, Jr., Mullen, M.W., Cox, D.P., and Stricker, G.D., 1992, Geology and geochronology of the Healy Quadrangle, south-central Alaska: U.S. Geological Survey Miscellaneous Investigations Series Map 1961, 63 p., 2 sheets, scale 1:250,000. http://dggs.alaska.gov/pubs/ id/12847

Csejtey, Béla, Jr., Nelson, W.H., Jones, D.L., Silberling, N.J., Dean, R.M., Morris, M.S., Lanphere, M.A., Smith, J.G., and Silberman, M.L., 1978, Reconnaissance geologic map and geochronology, Talkeetna Mountains Quadrangle, northern part of Anchorage Quadrangle, and southwest corner of Healy Quadrangle, Alaska: U.S. Geological Survey Open-File Report 78-558-A, 60 p., 1 sheet, scale 1:250,000. http://dggs.alaska. gov/pubs/id/12425 
Detterman, R.L., Hudson, Travis, Plafker, George, Tysdal, R.G., and Hoare, J.M., 1976, Reconnaissance geologic map along Bruin Bay and Lake Clark faults in Kenai and Tyonek quadrangles, Alaska: U.S. Geological Survey Open-File Report 76-477, 4 p., 1 sheet, scale 1:250,000. http://dggs.alaska.gov/pubs/id/11112

Dillon, J.T., and Reifenstuhl, R.R., 1995a, Geologic map of the Chandalar B-6 Quadrangle, southeastern Brooks Range, Alaska: Alaska Division of Geological \& Geophysical Surveys Professional Report 103, 1 sheet, scale 1:63,360. http://doi. org/10.14509/2284

1995b, Geologic map of the Chandalar C-6

Quadrangle, southeastern Brooks Range, Alaska: Alaska Division of Geological \& Geophysical Surveys Professional Report 105, 1 sheet, scale 1:63,360. http://doi.org/10.14509/2286

Dillon, J.T., Brosgé, W.P., and Dutro, J.T., Jr., 1986, Generalized geologic map of the Wiseman Quadrangle, Alaska: U.S. Geological Survey Open-File Report 86-219, 1 sheet, scale 1:250,000. http:// dggs.alaska.gov/pubs/id/12154

Dillon, J.T., Harris, A.G., Dutro, J.T., Jr., Solie, D.N., Blum, J.D., Jones, D.L., and Howell, D.G., 1988, Preliminary geologic map and section of the Chandalar D-6 and parts of the Chandalar C-6 and Wiseman C-1 and D-1 quadrangles, Alaska: Alaska Division of Geological \& Geophysical Surveys Report of Investigation 88-5, 1 sheet, scale 1:63,360. http://doi. org/10.14509/2453

Dillon, J.T., Reifenstuhl, R.R., Bakke, A.A., and Adams, D.D., 1989, Geologic map of the Wiseman A-1 Quadrangle, southcentral Brooks Range, Alaska: Alaska Division of Geological \& Geophysical Surveys Professional Report 98, 1 sheet, scale 1:63,360. http://doi.org/10.14509/2279

Dumoulin, J.A., Watts, K.F., and Harris, A.G., 1997, Stratigraphic contrasts and tectonic relationships between Carboniferous successions in the Trans-Alaska Crustal Transect corridor and adjacent areas, northern Alaska: Journal of Geophysical Research-Solid Earth, v. 102, no. B9, p. 20,709-20,726. http://doi. org/10.1029/97JB02350
Forbes, R.B., and Weber, F.R., 1982, Bedrock geologic map of the Fairbanks mining district, Alaska: Alaska Division of Geological \& Geophysical Surveys Alaska Open-File Report 170, 2 sheets, scale 1:63,360. http://doi.org/10.14509/106

Foster, H.L., Comp., 1992, Geologic map of the eastern Yukon-Tanana region, Alaska: U.S. Geological Survey Open-File Report 92-313, 26 p., 1 sheet, scale 1:500,000. http://dggs.alaska.gov/ pubs/id/11844

Frost, G.M., Barnes, D.F., and Stanley, R.G., 2002, Geologic and isostatic gravity map of the Nenana basin area, central Alaska: U.S. Geological Survey Geologic Investigations Series Map 2543, 16 p., 2 sheets, scale 1:250,000. http://dggs.alaska. gov/pubs/id/14830

Gilbert, W.G., and Redman, E.C., 1975, Geologic map and structure sections of Healy C-6 Quadrangle, Alaska: Alaska Division of Geological \& Geophysical Surveys Alaska Open-File Report 80, 3 p., 1 sheet, scale 1:40,000. http://doi. org/10.14509/176

Grantz, Arthur, Moore, T.E., and Roeske, S.M., 1991, Transect A-3; Gulf of Alaska to Arctic Ocean: Geological Society of America, Centennial Continent/Ocean Transect, no. 15, 3 sheets, scale 1:500,000.

Handschy, J.W.,1998, Regional stratigraphy of the Brooks Range and North Slope, Arctic Alaska, in Oldow, J.S., and Ave Lallemant, H.G., eds., Architecture of the central Brooks Range fold and thrust belt, arctic Alaska: Boulder, Colorado, Geological Society of America Special Paper 324, p. 1-8.

Harris, E.E., Mull, C.G., Reifenstuhl, R.R., and Montayne, Simone, 2002, Geologic map of the Dalton Highway (Atigun Gorge to Slope Mountain) area, southern Arctic Foothills, Alaska: Alaska Division of Geological \& Geophysical Surveys Preliminary Interpretive Report 2002-2, 1 sheet, scale 1:63,360. http://doi.org/10.14509/2867

Hawley, C.C., and Clark, A.L., 1973, Geology and mineral deposits of the Chulitna-Yentna mineral belt, Alaska: U.S. Geological Survey Professional Paper 758-A, p. A1-A10, 2 sheets, scale 1:500,000. http://dggs.alaska.gov/pubs/ id/4036 
Hickman, R.G., and Craddock, Campbell, 1976, Geologic maps of the west-central and central Healy Quadrangle, Alaska: Alaska Division of Geological \& Geophysical Surveys Alaska OpenFile Report 95, 3 sheets, scale 1:63,360. http:// doi.org/10.14509/191

Jones, D.L., Coney, P.J., Harms, T.A., and Dillon, J.T., 1988, Interpretive geologic map and supporting radiolarian data from the Angayucham terrane, Coldfoot area, southern Brooks Range, Alaska: U.S. Geological Survey Miscellaneous Field Studies Map 1993, 1 sheet, scale 1:63,360. http://dggs.alaska.gov/pubs/id/13091

Jones, D.L., Silberling, N.J., Gilbert, W.G., and Coney, P.J., 1983, Tectono-stratigraphic map and interpretive bedrock geologic map of the Mount McKinley region, Alaska: U.S. Geological Survey Open-File Report 83-11, 2 sheets, scale 1:250,000. http://dggs.alaska.gov/pubs/ id/12132

Keller, A.S., Morris, R.H., and Detterman, R.L., 1961, Geology of the Shaviovik and Sagavanirktok rivers region, Alaska: U.S. Geological Survey Professional Paper 303-D, p. 169-222, 6 sheets, scale 1:500,000. http://dggs.alaska.gov/pubs/ id/3831

Koehler, R.D., Farrell, Rebecca-Ellen, Burns, P.A.C., and Combellick, R.A., 2012, Quaternary faults and folds in Alaska: A digital database, in Koehler, R.D., Quaternary Faults and Folds (QFF): Alaska Division of Geological \& Geophysical Surveys Miscellaneous Publication 141, 31 p., 1 sheet, scale 1:3,700,000. http://doi. org/10.14509/23944

Labay, K.A., and Haeussler, P.J., 2001, GIS coverages of the Castle Mountain fault, south-central Alaska: U.S. Geological Survey Open-File Report 2001-504. http://pubs.er.usgs.gov/publication/ofr01504

Labay, K.A., Crews, Jesse, Wilson, F.H., Shew, Nora, Hults, C.K., Till, A.B., Dumoulin, J.A., Phillips, J.D., and Stanley, R.G., 2006, Preliminary integrated geologic map databases for the United States: digital data for the generalized bedrock geologic map, Yukon Flats region, eastcentral Alaska: U.S. Geological Survey Open-
File Report 2006-1304, 1 p. http://pubs.usgs. gov/of/2006/1304/

Moxham, R.M., and Eckhart, R.A., 1959, Geology and cement raw materials of the Windy Creek area, Alaska: U.S. Geological Survey Bulletin 1039-D, p. 67-100, 1 sheet, scale 1:48,000. http://dggs.alaska.gov/pubs/id/3597

Mull, C.G., and Adams, K.E., 1989, Bedrock geology of the eastern Koyukuk Basin, central Brooks Range, and east-central Arctic Slope along the Dalton Highway, Yukon River to Prudhoe Bay, Alaska: Alaska Division of Geological \& Geophysical Surveys Guidebook 7 v. 1, 309 p., 1 sheet, scale 1 inch $=45$ miles. http://doi. org/10.14509/269

Newberry, R.J., Bundtzen, T.K., Clautice, K.H., Combellick, R.A., Douglas, Tom, Laird, G.M., Liss, S.A., Pinney, D.S., Reifenstuhl, R.R., and Solie, D.N., 1996, Preliminary geologic map of the Fairbanks mining district, Alaska: Alaska Division of Geological \& Geophysical Surveys Public Data File 96-16, 17 p., 2 sheets, scale 1:63,360. http://doi.org/10.14509/1740

Patton, W.W., Jr., and Miller, T.P., 1973, Bedrock geologic map of Bettles and southern part of Wiseman quadrangles, Alaska: U.S. Geological Survey Miscellaneous Field Studies Map 492, 1 sheet, scale 1:250,000. http://dggs.alaska.gov/ pubs/id/12866

Péwé, T.L., Bell, J.W., Forbes, R.B., and Weber, F.R., 1975, Geologic map of the Fairbanks D-2 NW Quadrangle, Alaska: U.S. Geological Survey Miscellaneous Investigations Series Map 907, 1 sheet, scale 1:24,000. http://dggs.alaska. gov/pubs/id/12958

Péwé, T.L., Wahrhaftig, Clyde, and Weber, F.R., 1966, Geologic map of the Fairbanks Quadrangle, Alaska: U.S. Geological Survey Miscellaneous Geologic Investigations Map 455, 5 p., 1 sheet, scale 1:250,000. http://dggs.alaska.gov/ pubs/id/13676

Plafker, George, Gilpin, L.M., and Lahr, J.C., 1994, Neotectonic map of Alaska, in Plafker, George, and Berg, H.C., The Geology of Alaska: Geological Society of America, 2 sheets, scale 1:2,500,000. http://dggs.alaska.gov/pubs/ $\underline{\mathrm{id} / 22331}$ 
Reed, B.L., and Nelson, S.W., 1980, Geologic map of the Talkeetna Quadrangle, Alaska: U.S. Geological Survey Miscellaneous Investigations Series Map 1174, 15 p., 1 sheet, scale 1:250,000. http://dggs.alaska.gov/pubs/id/12942

Reger, R.D., 1981a, Geologic and materials maps of the Anchorage C-8 SE Quadrangle, Alaska: Alaska Division of Geological \& Geophysical Surveys Geologic Report 65, 2 sheets, scale 1:25,000. http://doi.org/10.14509/425

1981b, Geologic and materials maps of the Anchorage C-8 SW Quadrangle, Alaska: Alaska Division of Geological \& Geophysical Surveys Geologic Report 68, 2 sheets, scale 1:25,000. http://doi.org/10.14509/428

Reifenstuhl, R.R., Mull, C.G., Harris, E.E., Plumb, E.W., and Clough, J.G., 1993b, Preliminary bedrock geologic map of the Philip Smith Mountains D-3 Quadrangle, northeastern Brooks Range, Alaska: Alaska Division of Geological \& Geophysical Surveys Public Data File 93-80, 1 sheet, scale 1:63,360. http://doi.org/10.14509/1619

Reifenstuhl, R.R., Mull, C.G., Pessel, G.H., and Myers, M.D., 1993a, Preliminary bedrock geologic map of the Philip Smith Mountains C-4 Quadrangle, northeastern Brooks Range, Alaska: Alaska Division of Geological \& Geophysical Surveys Public Data File 93-30C, 11 p., 1 sheet, scale 1:63,360. http://doi.org/10.14509/1566

Robinson, M.S., 1983, Bedrock geologic map of the Livengood C-4 Quadrangle, east-central Alaska: Alaska Division of Geological \& Geophysical Surveys Report of Investigation 83-4, 1 sheet, scale 1:40,000. http://doi.org/10.14509/2343

Robinson, M.S., Smith, T.E., and Metz, P.A., 1990, Bedrock geology of the Fairbanks mining district: Alaska Division of Geological \& Geophysical Surveys Professional Report 106, 2 sheets, scale 1:63,360. http://doi.org/10.14509/2287

Sherwood, K.W., and Craddock, Campbell, 1979, General geology of the central Alaska Range between the Nenana River and Mount Deborah: Alaska Division of Geological \& Geophysical Surveys Alaska Open-File Report 116, 24 p., 3 sheets, scale 1:63,360. http://doi. org/10.14509/32
Steele, W.C., and Albert, N.R.D., 1978, Interpretation of Landsat imagery of the Talkeetna Quadrangle, Alaska: U.S. Geological Survey Miscellaneous Field Studies Map 870-C, 2 sheets, scale 1:250,000. http://dggs.alaska.gov/pubs/ id/13337

Till, Alison B., Dumoulin, Julie A., Harris, Anita G., Moore, Thomas E., Bleick, Heather, and Siwiec, Benjamin, geologic map compilers, and Labay, Keith A., Wilson, Frederic H., Bleick, Heather, and Shew, Nora B., 2008, Digital data for the geology of the southern Brooks Range, Alaska: U.S. Geological Survey Open-File Report OFR 2008-1149. http://pubs.usgs.gov/ of/2008/1149/

Wahrhaftig, Clyde, 1970a, Geologic map of the Fairbanks A-3 Quadrangle, Alaska: U.S. Geological Survey Geologic Quadrangle Map 809, 1 sheet, scale 1:63,360. http://dggs.alaska.gov/ pubs/id/12895

1970b, Geologic map of the Fairbanks A-4 Quadrangle, Alaska: U.S. Geological Survey Geologic Quadrangle Map 810, 1 sheet, scale 1:63,360. http://dggs.alaska.gov/pubs/id/13328 1970c, Geologic map of the Healy D-2 Quadrangle, Alaska: U.S. Geological Survey Geologic Quadrangle Map 804, 1 sheet, scale 1:63,360. http://dggs.alaska.gov/pubs/id/12897 Wahrhaftig, Clyde, and Black, R.F., 1958, Quaternary and engineering geology in the central part of the Alaska Range: U.S. Geological Survey Professional Paper 293, 118 p., 7 sheets, scale 1:250,000. http://dggs.alaska.gov/pubs/ id/3821

Weber, F.R., Wheeler, K.L., Rinehart, C.D., and Light, T.D., 1997, Generalized geologic map of the Livengood Quadrangle, Alaska: U.S. Geological Survey Open-File Report 97-484-A, 1 sheet, scale 1:250,000. http://dggs.alaska.gov/ pubs/id/12827

Wilson, F.H., Dover, J.H., Bradley, D.C., Weber, F.R., Bundtzen, T.K., and Haeussler, P.J., 1998, Geologic map of central (interior) Alaska: U.S. Geological Survey Open-File Report 98-133-A, 62 p., 3 sheets. http://pubs.usgs.gov/of/1998/ of $98-133-\mathrm{al}$ 
Wilson, F.H., Hults, C.P., Schmoll, H.R., Haeussler, P.J., Schmidt, J.M., Yehle, L.A., Labay, K.A., and Shew, N.B., 2009, Preliminary integrated geologic map databases for the United States: preliminary geologic map of the Cook Inlet region, Alaska: U.S. Geological Survey OpenFile Report 2009-1108. http://pubs.usgs.gov/ of/2009/1108/
Wilson, F.H., Labay, K.A., Mohadjer, Solmaz, and Shew, Nora, 2005, Preliminary integrated geologic map databases for the United States: digital data for the reconnaissance geologic map of the Kodiak Islands, Alaska: U.S. Geological Survey Open-File Report 2005-1340, 1 p. http://pubs. usgs.gov/of/2005/1340/ 